B O N N E V I L L E

Riparian Cottonwood Ecosystems and Regulated Flows in Kootenai and Yakima

Subbasins

Impact of Flow Regulation on Riparian Cottonwood Forests Along the Kootenai River in Idaho, Montana and British Columbia

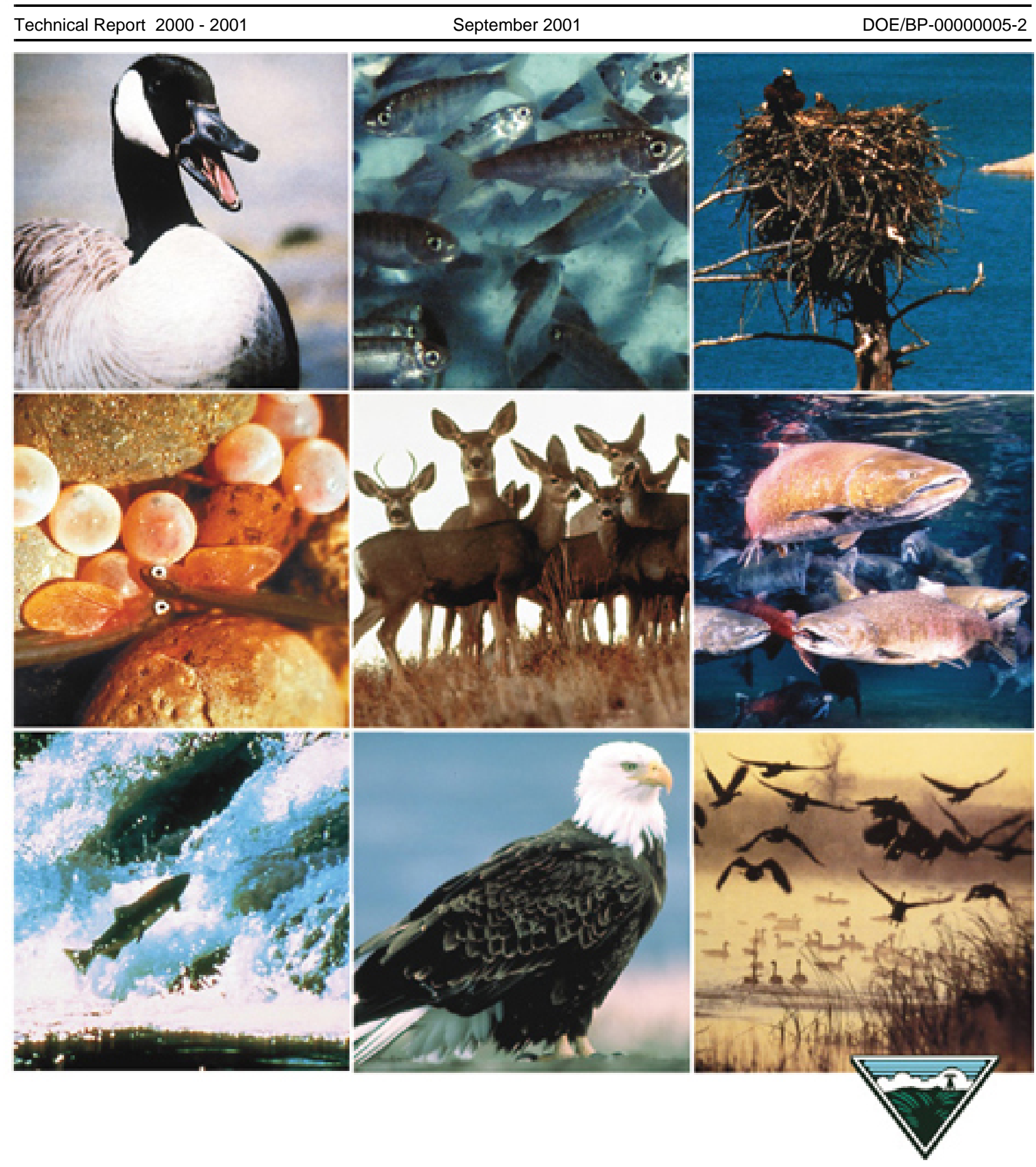


This Document should be cited as follows:

Jamieson, Bob, Jeffrey Braatne, "Riparian Cottonwood Ecosystems and Regulated Flows in Kootenai and Yakima Subbasins; Impact of Flow Regulation on Riparian Cottonwood Forests Along the Kootenai River in Idaho, Montana and British Columbia", 2000-2001 Technical Report, Project No. 200006800, 118 electronic pages, (BPA Report DOE/BP-00000005-2)

\author{
Bonneville Power Administration \\ P.O. Box 3621 \\ Portland, OR 97208
}

This report was funded by the Bonneville Power Administration (BPA), U.S. Department of Energy, as part of BPA's program to protect, mitigate, and enhance fish and wildlife affected by the development and operation of hydroelectric facilities on the Columbia River and its tributaries. The views in this report are the author's and do not necessarily represent the views of BPA. 


\title{
RIPARIAN COTTONWOOD
}

\section{ECOSYSTEMS \& REGULATED FLOWS \\ IN KOOTENAI \& YAKIMA SUB-BASINS}

\author{
Bob Jamieson \\ BioQuest International Consulting Ltd. \\ and \\ Jeff Braatne \\ University of Idaho
}

Contract No. 00000005

Project No. 2000-068-00

October 2001 


\section{AN OVERVIEW OF THE KOOTENAI AND YAKIMA RIPARIAN COTTONWOOD PROJECTS.}

\subsection{INTRODUCTION}

Riparian vegetation and especially cottonwood and willow plant communities are dependent on normative flows and especially, spring freshette, to provide conditions for recruitment. These plant communities therefore share much in common with a range of fish species that require natural flow conditions to stimulate reproduction. We applied tools and techniques developed in other areas to assess riparian vegetation in two very different sub-basins within the Columbia Basin. Our objectives were to:

- Document the historic impact of human activity on alluvial floodplain areas in both sub-basins.

- Provide an analysis of the impacts of flow regulation on riparian vegetation in two systems with very different flow regulation systems.

- Demonstrate that altered spring flows will, in fact, result in recruitment to cottonwood stands, given other land uses impacts on each river and the limitations imposed by other flow requirements.

- Assess the applicability of remote sensing tools for documenting the distribution and health of cottonwood stands and riparian vegetation that can be used in other sub-basins.

An overview of this work is presented here, more detailed information is provided in three separate reports as below.

1. The impact of flow regulation on riparian cottonwood forests along the Kootenai River in Idaho, Montana and British Columbia.

2. The impact of flow regulation on riparian cottonwood forests along the Yakima River.

3. A comparison of remote sensing tools for assessing the distribution of riparian cottonwood forests in the Columbia Basin.

Each is presented as a stand alone report and is available at the BPA website as separate document. Appendices to the major reports are included as separate files to minimize file size.

This work was funded under the innovative projects program of the NWPPC and BPA. 


\subsection{STUDY AREAS}

Maps of the study areas are provided in the separate reports. A description of some of the essential differences between the sub-basins is provided below.

Kootenai River: The Kootenai River is an international sub-basin with one major reservoir (Libby) mid-way on the portion of the river we looked at. There are few dams, none of which have significant storage, in the headwaters of this river. Irrigation removals are minor but diking for agricultural has had major impacts on the lower portion of the river. The hydrograph below Libby dam is highly regulated. Over the last decade, flows on the downstream reaches of this river have been manipulated to create a series of artificial spring freshettes aimed at stimulating spawning in white sturgeon. This gave us the opportunity to observe the response of native cottonwoods and willows to these experimental flow releases.

Yakima River: The Yakima River has several storage reservoirs in the upper reaches of the system. The major alluvial floodplains lower on the system support extensive areas of intensive agriculture. A significant proportion of the annual flow is removed from the river for irrigation. Agriculture, settlement and regulated flows have had a significant impact in the floodplain portions of the system. Flows vary substantially over the season in a manner that is referred to locally as "flip-flop". In this sub-basin our project benefited substantially from collaborative research activities on the alluvial floodplains of this system. A Bureau of Reclamation project, the Yakima Reaches Project under the direction of Dr. Jack A. Stanford of the University of Montana Flathead Biological Station has completed extensive work on the basic ecology of these alluvial floodplain areas.

\subsection{METHODS}

We applied six major tools is assessing riparian vegetation in these sub-basins.

1. A regional overview using Landsat and other data sources.

2. A historic assessment, using air photo interpretation comparing photos over a 50 to 80 year period, of riparian vegetation and land uses in three study reaches $(5-12 \mathrm{~km}$ in length) along portions of the main stem rivers in each sub-basin.

3. An assessment of the present distribution of cottonwood, using a range of remote sensing tools, in these study reaches.

4. An assessment of the health of riparian vegetation and cottonwood stands, based on vegetation transect data collected at 30 to 60 sites in each sub-basin on point bars both within and outside the major study reaches.

5. An assessment of annual and seasonal flow data for each study reach.

The methods used are described in detail in the separate reports. 


\subsection{RESULTS}

Kootenai River: We found that human impacts on the floodplain were much more extensive in the reaches below the Libby dam than in our study reaches upstream of the reservoir. Much of the lower river is diked and most of the floodplain is now farmland. Cottonwood stands do occur in the three downstream reaches however and we found recent cottonwood recruitment at three transect sites that has occurred as a result of spring flow releases for white sturgeon in the 1991 to 2000 period. The shape of these experimental releases varied widely between years and we were able to identify the years in which recruitment likely occurred.

Yakima River: We found extensive human impacts in all the alluvial reaches we studied. Unlike the Kootenai River however, there is still an active floodplain, between dikes and other constrictions, along most of the mainstem Yakima and its major tributaries. Gravel mining has had a major impact in many areas. Very little recruitment to cottonwood stands is occurring as a result of the highly modified flow regime in this sub-basin. This work provides a good basis for more detailed future studies that will be co-ordinated with other research and restoration activities in this sub-basin, especially the Yakima Reaches Project and riparian restoration projects being carried out by the Yakima Indian Nations.

Tools Assessment: We found that Landsat data was ineffective in providing a regional overview of cottonwood distribution, due to problems in differentiating between deciduous hardwood species. Forest cover available in Canada did provide a good overview of cottonwood distribution in the Canadian portion of the Kootenai sub-basin. It appears that new hyper-spectral satellite data may allow the separation of deciduous species and could play a role in future work.

At a study reach scale we found that traditional visual typing of vegetation types from air photos, ADAR and IKONOS all could be used to document the distribution of cottonwood stands and other riparian vegetation types. Each approach had positive attributes, some limitations and varied in cost. Hymap, a new hyper-spectral data source (flown at low elevation) has been used to separate deciduous species in the Yellowstone area. This tool will be of major value in future studies of riparian vegetation. 


\subsection{CONCLUSIONS}

Our most important conclusions are that:

- Major losses to riparian vegetation and ecological function have occurred in response to regulated flows in both river systems.

- There are major differences in the seasonal hydrograph and the impact of other land uses in each sub-basin. As a result, separate strategies for managing regulated flows to maintain riparian vegetation are required in each sub-basin.

- On the Kootenai, we found clear evidence that spring releases do in fact result in the establishment of cottonwood recruitment, as has been documented in other basins.

- This work provides the science and the conceptual tools for managers to integrate the requirements of cottonwood and riparian vegetation into the complex mix of flow demands found in each sub-basin.

- This work has also allowed us to develop tools that can be used effectively and efficiently to document the status of riparian vegetation along rivers in other parts of the Columbia Basin.

The recent report by the Independent Scientific Advisory Board on salmon recovery strategies provides an analysis of the various planning strategies in the Basin and good advice on future direction for restoration work. They note that natural disturbance events, such as flood events, have not been given sufficient consideration in past planning. They also indicate that management is moving from more artificial management strategies toward the restoration of ecological function. A move toward more normative flows on regulated rivers is a critical element of this strategy and should be an important feature of future restoration efforts. We see our work as an important element in this move toward more normative conditions that will generate important benefits in re-establishing ecological function and providing important habitat improvements for both fish and wildlife species. 


\section{THE IMPACT OF FLOW REGULATION ON RIPARIAN COTTONWOOD FORESTS ALONG THE KOOTENAI RIVER IN IDAHO, MONTANA AND BRITISH COLUMBIA.}

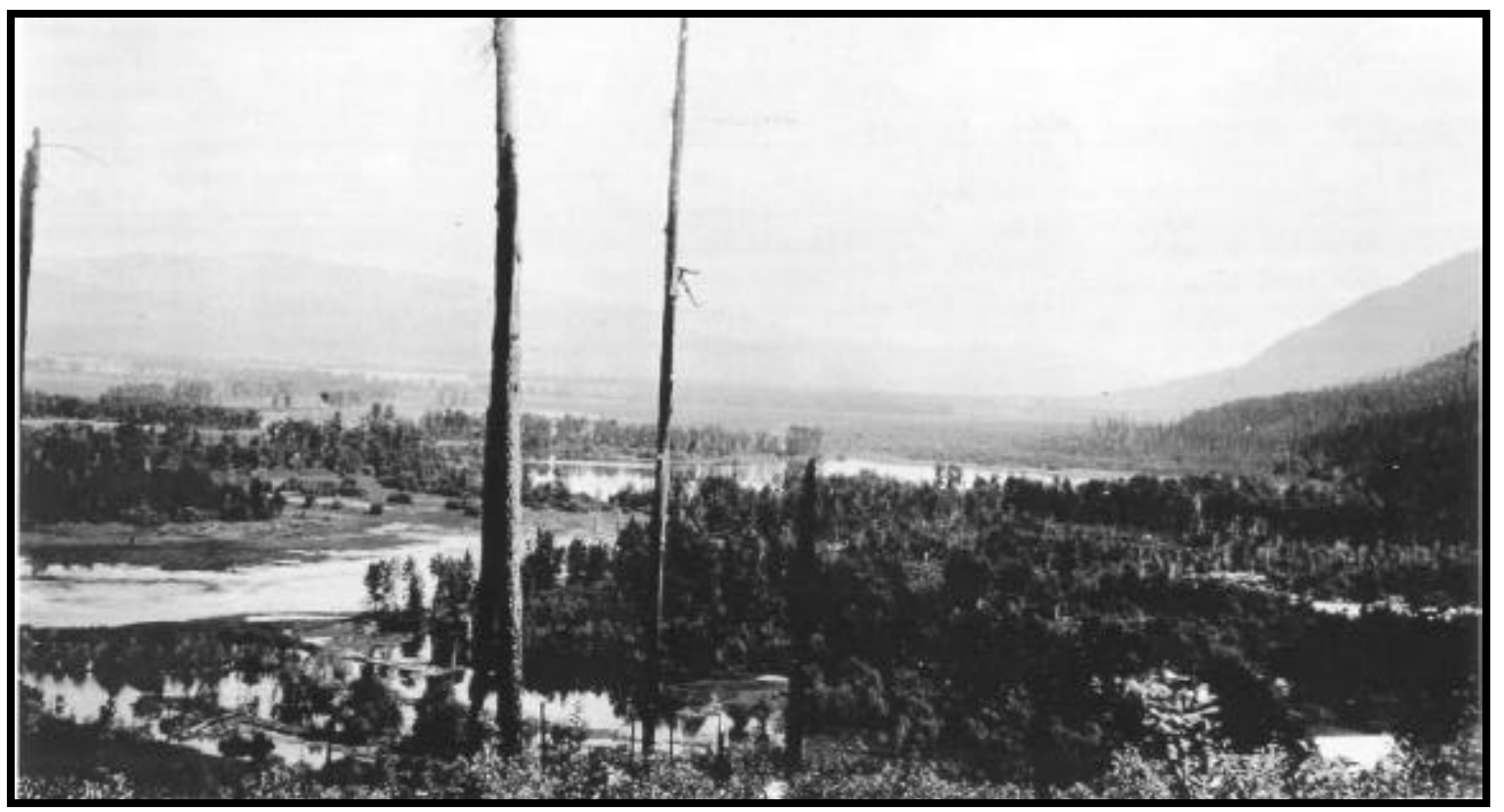

\section{FOR: BONNEVILLE POWER CORPORATION PORTLAND, OREGON.}

BY: Bob Jamieson - BioQuest International Consulting Ltd.

Dr. Jeffrey Braatne, University of Idaho.

September 30, 2001.

* The photograph above shows the cottonwood, sedge meadow and wetlands complexes of the Kootenai River floodplain prior to extensive settlement and the construction of the Libby dam. The photo was taken near the US-Canada border in 1914, looking south-east toward Copeland, Idaho. (USDA 1914). 


\section{EXECUTIVE SUMMARY}

Riparian cottonwood stands depend on a natural hydrograph and especially, spring freshette, to provide the conditions necessary for the establishment of new cohorts of young cottonwood and willow. In this cooperative, international study we looked at the status of cottonwoods along the Kootenai River both in Canada and the USA. We collected data on land use changes, river flows and riparian vegetation in three study reaches; one above and two below the Libby dam. We found that relatively minor land use changes have occurred in the upstream reach but that major impacts from diking and agricultural development of the floodplain had occurred in the downstream reaches. One of the downstream reaches, from the Moyie confluence to Bonner's Ferry is unconstrained by diking, thus allowing natural channel migration and other ecological functions to occur. The major downstream alluvial floodplain reach, from Bonner's Ferry to Kootenay Lake, is restricted by dikes for most of its length. Due to regulated flows (high and irregular winter flows and a lack of spring freshette) below Libby Dam from 1975 to 1990, there has been very little recruitment to cottonwood stands in these downstream reaches. However, spring flow releases from 1991 to 2000, aimed at promoting spawning for white sturgeon, resulted in conditions in some years that resulted in the establishment of new cottonwood stands in the Moyie confluence to Bonner's Ferry reach and in one area further downstream near Copeland. Cottonwoods appear to have established in 1996 or 1997 when the rate of recession on the declining limb of the hydrograph (following peak spring flows) was within the range required for cottonwood recruitment. Seasonal flows and ramping rates for the Kootenai River below Libby dam (for the 2001-2003 period) are specified in the Year 2000 Biological Opinion for white sturgeon and bull trout. We provide recommendations for future downward ramping rate and summer flows that will be required to provide for cottonwood recruitment as part of the mix of benefits being provided by these releases. 


\section{THE IMPACT OF FLOW REGULATION ON COTTONWOOD FORESTS ALONG THE KOOTENAI RIVER IN IDAHO, MONTANA AND BRITISH COLUMBIA.}

\section{TABLE OF CONTENTS}

EXECUTIVE SUMMARY

Page

TABLE OF CONTENTS

LIST OF FIGURES 2

LIST OF TABLES .5

ACKNOWLEDGEMENTS

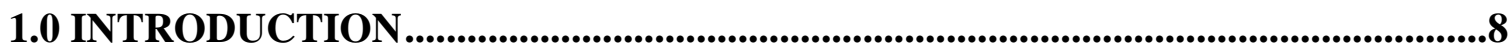



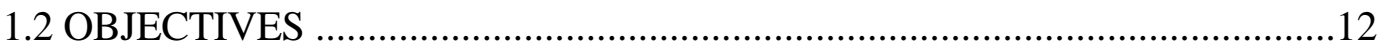

2.0 STUDY AREA....................................................................................................................13

3.0 METHODS …….........................................................................................................................20

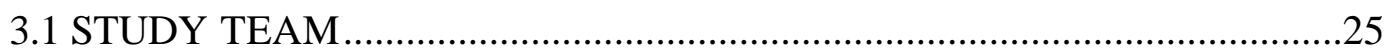

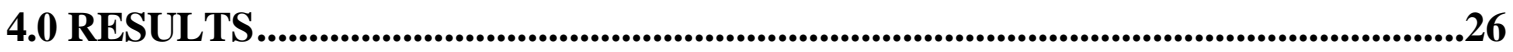

4.1 SKOOKUMCHUCK TO WARDNER REACH.........................................26

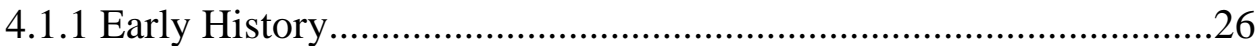

4.1.2 Present sub-basin status of cottonwoods.......................................27

4.1.2 Pre and post dam hydrographs ..................................................27

4.1.3 Wasa Bridge to Cherry Creek Study Reach.....................................29

4.1.3.1 Riparian Habitat Change in recent decades.......................29

4.1.3.2 Present distribution of cottonwood stands ........................34

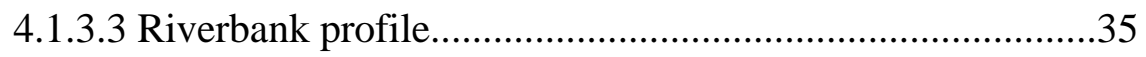



4.1.3.5 The distribution of tree species by elevation....................39

4.1.3.6 Stand Health...................................................................39

4.2 WARDNER TO LIBBY DAM REACH ....................................................40

4.3 LIBBY DAM TO MOYIE REACH........................................................40

4.3.1 Pre and post dam hydrographs ...................................................41 
4.4 MOYIE CONFLUENCE TO BONNER'S FERRY REACH.........................43

4.4.1 Early History ...............................................................................43

4.4.2 Pre and post dam hydrographs .........................................................43

4.4.3 Moyie Confluence to Bonner's Ferry Study Reach.............................45

4.4.3.1 Riparian Habitat Change in recent decades..........................45

4.4.3.2 Present distribution of cottonwood stands .........................49

4.4.3.3 Riverbank profile.............................................................51

4.4.3.4 Riverbank plant communities...........................................51

4.4.3.5 The distribution of tree species by elevation......................54

4.4.3.6 Stand Health....................................................................54

4.5 BONNER'S FERRY TO KOOTENAY LAKE REACH ................................55

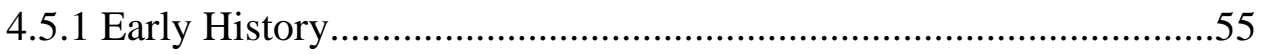

4.5.2 Pre and post dam hydrographs ....................................................56

4.5.3 Deep Creek to Shortie's Island Reach..............................................57

4.5.3.1 Riparian Habitat Change in recent decades........................57

4.5.3.2 Present distribution of cottonwood stands ..........................61

4.5.3.3 Riverbank profile............................................................62

4.5.3.4 Riverbank plant communities.............................................62

4.5.3.5 The distribution of tree species by elevation.......................64

4.5.3.6 Stand Health.........................................................................64

4.5.4 Shortie's Island to Copeland Bridge Study Reach.............................65

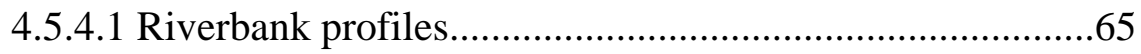

4.5.4.2 Riverbank plant communities............................................65

4.5.4.3 The distribution of tree species by elevation......................67

4.5.4.4 Stand Health.......................................................................67

4.5.5 Copeland Bridge to Border Reach...................................................68

4.5.6 Border to Duck Lake Reach............................................................68

4.5.7 Duck Lake to Kootenay Lake Study Reach......................................68

4.5.7.1 Riverbank profiles..............................................................69

4.5.7.2 Riverbank plant communities..............................................69

4.5.7.3 The distribution of tree species by elevation.......................72

4.5.7.4 Stand Health......................................................................72

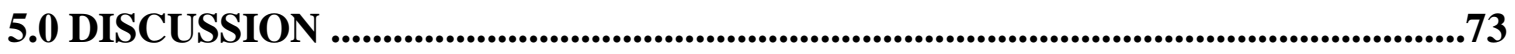

5.1 PRESENT STATUS OF RIPARIAN VEGETATION ...................................73

5.2 THE RELATIONSHIP BETWEEN FLOWS AND COTTONWOODS .........74

5.3 ANALYSIS OF THE ANNUAL HYDROGRAPH, 1991-2000.....................76

6.0 RECOMMENDATIONS..................................................................................................82

6.1 FLOW MANAGEMENT OPTIONS TO MAINTAIN RIPARIAN

COTTONWOOD HABITATS BELOW THE LIBBY DAM ………....................82

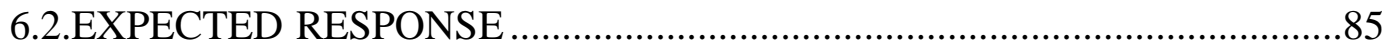




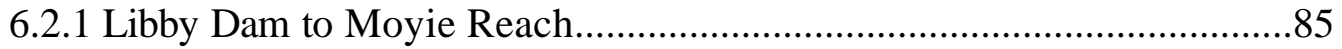

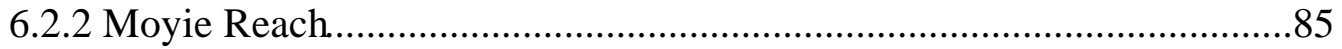

6.2.3 Bonner's Ferry to Kootenay Lake Reach............................................85

6.3 OTHER MANAGEMENT OPTIONS FOR MAINTAINING

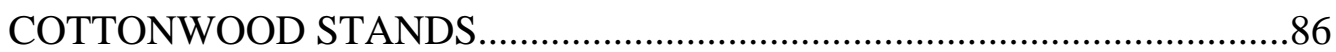

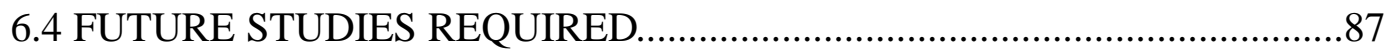

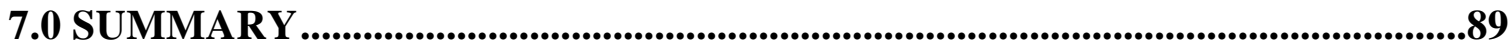

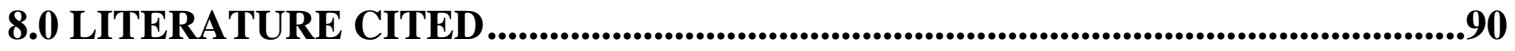

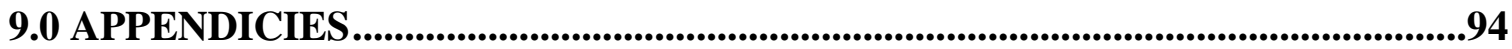

Appendix I. Photographs of transect sites in each study reach.

Appendix II. Historic and recent photographs, mapping and aerial photographs of the Kootenai River floodplain near the US/Canada border.

Appendix III. Other management options for maintaining cottonwood stands along the Kootenai River.

(These appendices are provided as separate files on the bpa website) 


\section{LIST OF FIGURES}

Figure 1. A representative daily hydrograph for large alluvial rivers in western North America prior to the construction of major dams upstream. ...............................

Figure 2. The location of our study areas in the Columbia Basin..................................11

Figure 3. The major river reaches of the Kootenai River sub-basin. ..............................16

Figure 4. The Canal Flats to Wardner alluvial reach and the Wasa to Cherry Creek study reach................................................................................................... 17

Figure 5. The Moyie confluence to Bonner's Ferry and Bonner's Ferry to

Kootenay Lake alluvial reaches and study reaches....................................................18

Figure 6. The Bonner's Ferry to Kootenay Lake alluvial reach (Canadian portion)

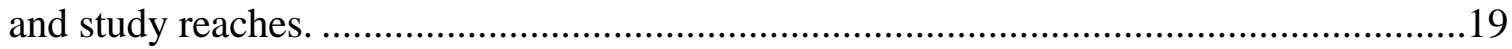

Figure 7. Annual Hydrograph at Fort Steele, 1964-1990 ..............................................28

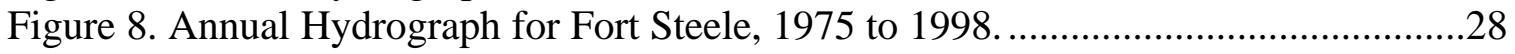

Figure 9. Habitat mapping for the Wasa study reach, 1952 .........................................30

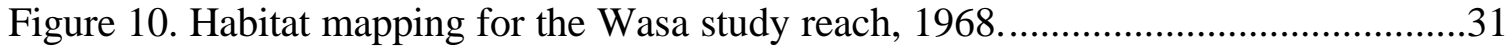

Figure 11. Habitat mapping for the Wasa study reach, 1994 .........................................32

Figure 12. The distribution of cottonwood stands in the Wasa study reach. ....................35

Figure 13. Elevation Profiles for 9 transects in the Wasa study reach.............................36

Figure 14. The distribution of grasses relative to September flows in the Wasa

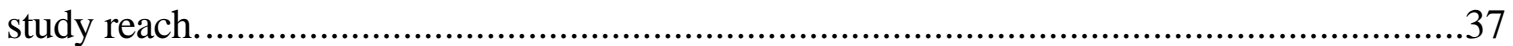

Figure 15. The distribution of forbs relative to September flows in the Wasa

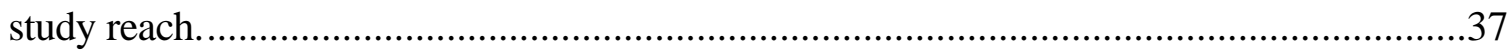

Figure 16. The distribution of woody shrubs relative to September flows in the

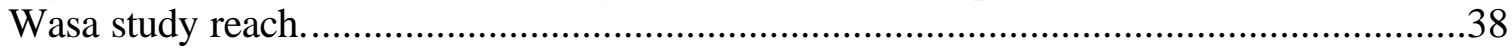

Figure 17. The distribution of tree species relative to September flows in the

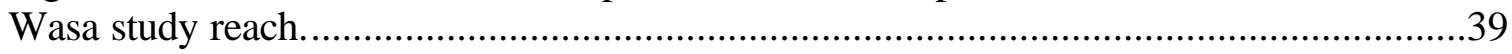

Figure 18. Pre-dam annual hydrograph at Libby, Montana, 1955 to $1970 \ldots \ldots \ldots \ldots \ldots . . . . . . . . . .41$

Figure 19. Post-dam annual hydrograph at Libby, Montana, 1975 to 1990 .....................41

Figure 20. Post-dam annual hydrograph at Libby, Montana, 1991 to 2000. ...................42

Figure 21. Daily stage at Bonner's Ferry, 1963-1971................................................44

Figure 22. Daily stage at Bonner's Ferry, 1975-1990..................................................44

Figure 23. Daily stage at Bonner's Ferry, 1991-2000.................................................44

Figure 24. Habitat and land use mapping for the Moyie study reach, 1934..............46

Figure 25. Habitat mapping for the Moyie study reach, 1968 ....................................47

Figure 26. Habitat mapping for the Moyie study reach, 1991 .......................................48

Figure 27. The present distribution of mature and immature cottonwood stands in

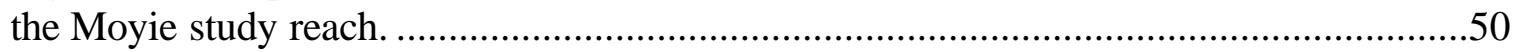

Figure 28. Elevation profiles for transects in the Moyie study reach. .............................51

Figure 29. The distribution of grasses relative to September flows in the Moyie

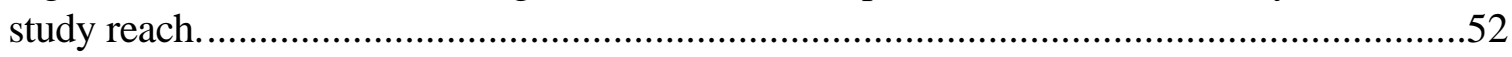

Figure 30. The distribution of forbs relative to September flows in the Moyie study reach. 
Figure 31. The distribution of woody shrubs relative to September flows in the

Moyie study reach.

Figure 32. The distribution of tree species relative to September flows in the

Moyie study reach.

Figure 33. Habitat and Land Use types in the Shortie's Island study reach, 1934..........58

Figure 34. Habitat and Land Use types in the Shortie's Island study reach, 1968...........59

Figure 35 Habitat and Land Use types in the Shortie's Island study reach, 1991

Figure 36. The present distribution of cottonwood stands in the Shortie's Island

study reach.

Figure 37. Elevation profiles for transects in the Shortie's Island study reach.

Figure 38. The distribution of perennial grasses relative to September flows in the

Shortie's Island study reach.

Figure 39. The distribution of forbs relative to September flows in the

Shortie's Island study reach.

Figure 40. The distribution of tree species relative to September flows in the

Shortie's Island study reach. .64

Figure 41. Elevation profiles for transects in the Copeland study reach.

Figure 42. The distribution of grasses relative to September flows in the

Copeland study reach.

Figure 43. The distribution of forbs relative to September flows in the

Copeland study reach.

Figure 44. The distribution of tree species relative to base September flows in the

Copeland study reach.

Figure 45. Elevation profiles for transects in the Kootenay Lake study reach.

Figure 46. The distribution of grasses relative to September water levels in

Kootenay Lake, in the Kootenay Lake study reach.

Figure 47. The distribution of forbs relative to September water levels in

Kootenay Lake, in the Kootenay Lake study reach. .70

Figure 48. The distribution of woody shrubs relative to September water

levels in Kootenay Lake, in the Kootenay Lake study reach.

Figure 49. The distribution of tree species relative to September water

levels in Kootenay Lake, in the Kootenay Lake study reach...... . .72

Figure 50. The Recruitment Box Model. ......................................................................75

Figure 51. Daily elevation of the Kootenai River at Bonner's Ferry, 1991_....................77

Figure 52. Daily elevation of the Kootenai River at Bonner's Ferry, 1992 ......................77

Figure 53. Daily elevation of the Kootenai River at Bonner's Ferry, 1993 .....................77

Figure 54. Daily elevation of the Kootenai River at Bonner's Ferry, 1994........................78

Figure 55. Daily elevation of the Kootenai River at Bonner's Ferry, 1995......................78

Figure 56. Daily elevation of the Kootenai River at Bonner's Ferry, 1996......................79

Figure 57. Daily elevation of the Kootenai River at Bonner's Ferry, 1997......................79

Figure 58. Daily elevation of the Kootenai River at Bonner's Ferry, 1998......................80

Figure 59. Daily elevation of the Kootenai River at Bonner's Ferry, 1999.....................81

Figure 60. Daily elevation of the Kootenai River at Bonner's Ferry, 2000.....................81 


\section{LIST OF TABLES}

Table 1. The area (ha) of different habitat types in the Wasa to Cherry Creek reach in 1952, 1968 and 1994.

Table 2. The area (ha) of different habitat types in the Moyie study reach in 1934, 1968 and 1996.

Table 3. The area (ha) of different habitat types in the Shortie's Island study reach in 1934,1968 and 1996.

\section{ACKNOWLEDGEMENTS}

We wish to acknowledge the assistance and contributions to this project of Tom Morse, our contract manager at BPA, Dr. Jack Stanford, Dr. Stewart Rood, Dr. Mike Merigliano, the review team for the project, Sue Ireland and Scott Soults of the Kootenai Tribe Resource Management office at Bonner's Ferry, Brian Moratz, Montana Fish, Wildlife and Parks and our field crew.

\section{CITATION}

Jamieson, B., and J. Braatne. 2001. The impact of flow regulation on cottonwood forests along the Kootenai River in Idaho, Montana and British Columbia. By: BioQuest International Consulting Ltd. For: Bonneville Power Corporation, Portland, Or. Available at http://www.efw.bpa.gov/cgi-bin/FW/publications.cgi

Bob Jamieson

\section{CONTACTS}

President

BioQuest International Consulting Ltd.

Box 73,

Ta Ta Creek, B.C.]

VOB $2 \mathrm{HO}$

bjamieson@ cintek.com

Dr. Jeff Braatne

Asst. Professor of Riparian Ecology

Dept. of Fish, Wildlife and Range Resources

University of Idaho

Moscow, ID 83844

braatne@uidaho.edu 


\section{THE IMPACT OF FLOW REGULATION ON COTTONWOOD FORESTS ALONG THE KOOTENAI RIVER IN IDAHO, MONTANA AND BRITISH COLUMBIA.}

\subsection{INTRODUCTION}

Riparian habitats are critical to the health of river systems and the fish and wildlife species that use riparian and aquatic ecosystems. In this report we describe the status and function of cottonwood stands and associated riparian vegetation on the Kootenai River. This is an international watershed that includes portions of British Columbia, Montana and Idaho. Under pre-settlement conditions, alluvial flood plains with complex multiple channels, underlying alluvial aquifers and extensive cottonwood stands were a major feature of this system. The construction of the Libby dam was completed in 1975. The Libby Reservoir (also called Lake Koocanusa), inundates about 1/3 of the length of the mainstem Kootenai, including two major alluvial reaches. Flow regulation below Libby dam has altered the hydrograph on this river and has had major impacts on riparian vegetation and on fish and wildlife species that depend on that vegetation (Polzin and Rood 2000). This impact and the effects of other land uses, primarily clearing for agriculture and settlement, have lead to severe reductions in the area of active floodplain, channel simplification and have impaired ecosystem function. Fish and wildlife production along this river has been reduced dramatically as a result (Moritz et al. 2000). Many authors have described the wide range wildlife and fish species that depend on healthy riparian vegetation and normative river flows. Jamieson et al. 2001 provides a description of the use of riparian cottonwood stands by wildlife and fish species in this Canadian portion of the Columbia River basin that is descriptive of their role on the Kootenai River.

This work was funded under innovative projects program of the North West Power Planning Council (NWPPC) and Bonneville Power Authority (BPA); Project No. 20034. This is part 1 of 3 reports that are being generated to meet the objectives established under this project. This work was completed between June 30, 2000 and September 30, 2001.

\subsection{BASIC CONCEPTS}

The recruitment of cottonwood seedlings along rivers is dependent on dynamic fluvial processes and spring freshette (Bradley and Smith 1984, Rood and Mahoney 1990, Braatne et al. 1996, Mahoney 1996, Scott et al. 1996). (See Figure 1). Dynamic seasonal flow patterns, combined with periodic spring flooding, produce moist, barren substrates that are necessary for seedling recruitment (Bradley and Smith 1986, Rood and Mahoney1990, Rood and Mahoney 1994, Scott et al. 1996). After germination on these nursery sites, the roots of young seedlings must also keep pace with declining river levels (root growth averages $2.5 \mathrm{~cm}$ per day); Mahoney and Rood 1991, 1992, 1998, Selgelquist et al. 1993, Johnson 1994, Rood et al. 1995). If river levels decline too rapidly, young 
seedlings rapidly succumb to drought stress. Older cottonwood stands are also dependent on periodic flooding and recharging of the alluvial water table (Johnson and Jones 1977; Rood and Heinze-Milne 1989; Rood and Mahoney 1990; Snyder and Miller 1991;

Stromberg and Patten 1992). Dams that attenuate spring peakflows and reduce summer base flows induce significant levels of drought stress among all age-classes, and thereby promote a decadent age- structure among local populations (Fenner et al. 1985, Bradley and Smith 1986, Rood and Mahoney 1990, Stomberg and Patten 1991, Scott et al. 1996). This can eventually lead to the loss of these ecologically important stands.



Figure 1. A representative daily hydrograph for large alluvial rivers in western North America prior to the construction of major dams upstream. Roman numerals represent important components relevant to the recruitment of poplar seedlings: (I) high flows drive geomorphic processes that create suitable moist and barren nursery sites, (II) falling flows expose the nursery sites, (III) gradual flow decline after germination permits the growing roots to maintain contact with the receding moisture zone, (IV) sufficient flows through the hot and dry period of mid- to late summer, and (V) sufficient flows in late summer and autumn provide seedlings with a favorable water balance to withstand the winter months (modified from Mahoney and Rood 1998).

Work on many other rivers in North America has demonstrated that flow regulation has severe impacts on downstream cottonwood stands. Several studies from across western 
North America have found a steady decline of the extent and health of riparian cottonwood ecosystems (Rood and Mahoney 1990; Bradley et al. 1991, Braatne et al. 1996, Mahoney 1996). The primary causes of these declines have been woodland clearing and impacts due to water diversions and damming (Braatne et al. 1996). Most of the studies on dam-induced declines have occurred along rivers on the great plains that support prairie and Fremont cottonwoods (Johnson et al. 1976, Bradley and Smith 1986, Rood and Heinze-Milne 1989, Rood and Mahoney 1990, Rood and Bradley 1993, Snyder and Miller 1991, Stromberg and Patten 1992 and Johnson 1992. More recently, work has been initiated on Black Cottonwood along the Columbia River in Canada (Rood et al. 1995) and on the Kootenai River (Polzin and Rood 2000). This research has shown that declines in riparian cottonwoods are caused primarily by the suppression of seedling recruitment. Since cottonwoods are a relatively short-lived tree (100-200 years), declines in recruitment over the past century have lead to the widespread loss of riparian cottonwood ecosystems.

In recent years, some researchers have successfully applied their knowledge of the life history and ecology of cottonwoods to promote natural patterns of recruitment below dams on some western rivers (Rood and Gourley 1996, Rood and Kalischuk 1998). In these cases, high water volumes available during "wet years" were released in a manner that was compatible with seed dispersal and establishment of cottonwood seedlings. These practices are now widely accepted and promoted by resource managers in Alberta (Mahoney 1997) and Nevada (Rood and Gourley 1996).

This report is intended to provide a better understanding of the impact of flow regulation on riparian cottonwood stands on the lower reaches of the Kootenai River following the construction of Libby dam and developing options for mitigating those impacts. Similar work has been completed on the Yakima River as part of the same project (Figure 2). 


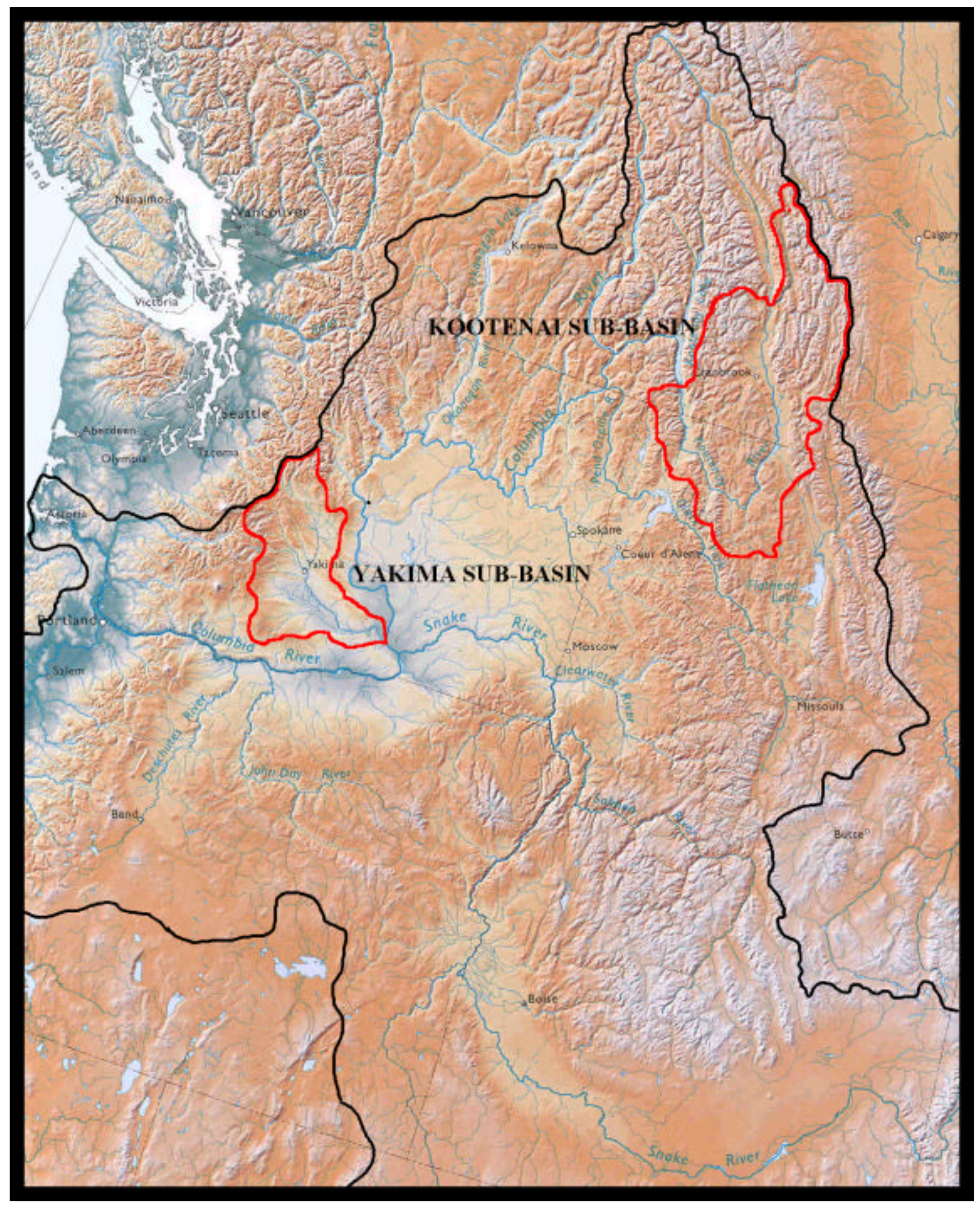

Figure 1. The Location of the study basins within the Columbia Basin. 


\subsection{OBJECTIVES}

The objectives and related tasks in this project were to:

OBJECTIVE 1: Provide a general overview of the status of the major alluvial floodplains of the Upper Kootenai River prior to 1930.

OBJECTIVE 2: Provide an assessment of the status of riparian cottonwood stands and related riparian habitat types on alluvial floodplains on the Upper Kootenai River prior to the construction of the Libby dam in 1968-72.

Task 2a: Document changes in riparian vegetation on sample reaches in alluvial floodplain reaches upstream and downstream of the Libby dam, by comparing historic and recent air photos.

OBJECTIVE 3: Document the present distribution of riparian cottonwood stands in the major alluvial floodplains of the Kootenai River.

Task 3a: Provide mapping of the present distribution of riparian cottonwood stands in three study reaches on the Kootenai River.

OBJECTIVE 4: Document stand health and recruitment to riparian cottonwood stands and related riparian habitat types in the major alluvial floodplains of the Kootenai River.

Task 4a: Document stand health and recruitment to riparian cottonwood stands and related riparian habitat types in three study reaches in the Upper Kootenai sub-basin using vegetation transects.

OBJECTIVE 5: Document the pre and post-dam seasonal flow regime of the Kootenai River.

Task 5a: Document the seasonal hydrograph on the Kootenai River upstream of Libby Dam.

Task 5b: Document the seasonal hydrograph on the Kootenai River downstream of Libby Dam, prior to and following the construction of the dam.

Task 5c: Document the seasonal hydrograph on the Kootenai River downstream of Libby Dam, for the 1991 to 1999 era during which experimental spring releases were tested as part of the Kootenai white sturgeon recovery program.

OBJECTIVE 6: Document the relationship between seasonal flow regimes and cottonwood abundance and stand health.

OBJECTIVE 7: Document flow management options to maintain riparian cottonwood habitats below Libby Reservoir.

Task 7a: Apply our understanding of cottonwood ecology and river dynamics to define options for using manipulated flows to re-establish cottonwood recruitment below Libby dam. 


\subsection{STUDY AREA}

The Kootenai River originates close to the continental divide in Kootenay National Park in the Canadian Rockies and flows some $775 \mathrm{~km}$ (485 mi.) through both Canada and the US before entering the Columbia at Castlegar, B.C. (Figure 3). In terms of runoff volume, the Kootenai is the second largest Columbia River tributary. In terms of watershed area $\left(36,000 \mathrm{~km}^{2}\right.$ or 8.96 million acres), it ranks third (Knudson 1994, cited in Moritz et al. 2000.). Our study area was that portion of the sub-basin above the river's outflow into Kootenay Lake. The Upper Kootenai* receives flows from the Canadian Rockies and the Purcell Range in Canada. Tributaries from both of these ranges flow into the Rocky Mountain Trench. These tributaries have delivered large volumes of gravel and silts to the alluvial reaches on this portion of the river, creating a wide floodplain one to three $\mathrm{km}$ (1-1.5 mi.) wide that is 50 to $100 \mathrm{~m}$ (150 to 300 vertical feet) below the general level of the Trench. Precipitation is high in the adjacent ranges and low in the Rocky Mountain Trench with most precipitation coming in the form of snow between October and March. This is a very dynamic river with a massive spring freshette in some years. The unregulated hydrograph at Bonner's Ferry, prior to 1972, in the lower portion of the river, showed annual peaks in April through June in the range of $10 \mathrm{~m}$. (30 feet) above low flow levels. Pre-dam spring flows are often in excess of 1,700 cms $(60,000$ cfs) and historically were above 4,250 cms (150,000 cfs) in many years $(1894,1948$, 1950, 1954, 1956 and 1961. Minimum winter flows on the lower river, prior to regulation, were from 113-226 cms (4-8,000 cfs) (USFWS 2000). A detailed description of the hydrology of the river and other land uses in the basin are provided by Moratz et al. 2000 .

The Upper Kootenai River can be divided into 5 major reaches (Figure 3).

1. Skookumchuck to Wardner Reach: Although several alluvial reaches occur at higher elevation on the mainstem of the Kootenai in Kootenay National Park and in several of its tributaries; the first major mainstem alluvial reach extends from Canal Flats, where the river enters the Trench, to Wardner, B.C. at the head of the Libby Reservoir. Along this reach, fluvial outflows from major tributary rivers, (Skookumchuck, St. Mary's, Wildhorse and Bull Rivers) have created four hydraulic dams that result in slowed current and silt deposition areas upstream of the inflow and cobble reaches downstream. We looked in detail at one of these silt deposition areas, from the Wasa bridge to Cherry Creek (Figure 4.).

* Our study area, referred to as the Upper Kootenai sub-basin, does not include the lower portion to the river in Canada that includes Kootenay Lake and the Kootenay River between Kootenay Lake and the Columbia River at Castlegar. The Canadian portion of the Kootenai River is known as the Kootenay River. For simplicity we have used the description "Upper Kootenai" or "Kootenai" to describe the entire upper river and Basin, in both the USA and Canada. Kootenay Lake is described as such since it is the proper place name for that body of water. Lake Koocanusa is the popular name for the Libby Reservoir. We have used the latter term. 
2. Libby Reservoir Reach: We have treated the portion of the river inundated by the Libby Reservoir as a single "reach". Prior to flooding, alluvial reaches occurred upstream and downstream of the confluences of Sand Creek and the Elk River. The cobble reach below the Elk River was extensive and extended to Rexford, Montana. Below that town the river entered a narrow valley that extended as far as the present day Libby dam.

3. Libby Dam to Moyie River Reach: Downstream of the dam there is a major reach $(92 \mathrm{~km})$ that flows through a narrow mountain valley and has a limited floodplain. In the lower portion it flows through a canyon. The substrate consists of large cobble and gravel (Synder and Minshall 1996).

4. Moyie River to Bonner's Ferry Reach: The reach downstream of the Moyie River confluence to Bonner's Ferry is very different from the previous reach. It breaks out of the upstream canyon into the wide $(5-10 \mathrm{~km})$ Bonner's Ferry valley. This reach is extensively braided and is generally $<9 \mathrm{~m}$ in depth. Substrates consist mostly of gravels. The river has an average gradient of $0.6 \mathrm{~m} / \mathrm{km}(2.4 \mathrm{ft} / \mathrm{mi})$, and velocities $<0.8 \mathrm{~m} / \mathrm{s}$ (Synder and Minshall 1996). This reach has been diked but the dikes are set back from the river channel and allow for some channel migration. We treated the entire Moyie confluence to Bonner's Ferry reach as a study reach (Figure 5).

5. Bonner's Ferry to Kootenay Lake Reach: This reach extends from just below the town of Bonners Ferry to Kootenay Lake in Canada, a distance of $82.5 \mathrm{~km}$ (51.5 mi.). The river meanders across a large alluvial floodplain for the entire distance. The average gradient is $0.02 \mathrm{~m} / \mathrm{km}(.8 \mathrm{ft} / \mathrm{mi})$. The river channel is characterized by water depths of up to 12 meters in runs and up to 30 meters in pools (Snyder and Minshall 1994). Most of this floodplain area is made up of clay, silt and sand substrates. This reach has been extensively diked and channelized along almost all of its length. We looked in detail at a study reach from Deep Creek to Shortie's Island which was representative of most of the larger reach (Figures 5 and 6). We also established transects in two study reaches further downstream where point bars occur below the level of the dike (Shortie's Island to Copeland Reach) and where the river flows into Kootenay Lake (Duck Lake to Kootenay Lake Reach)(Figure 6).

The three major study reaches represent a silt based alluvial system with a natural hydrograph, (Wasa-Cherry Creek); an unconstrained, braided, cobble based reach with a regulated hydrograph (Moyie confluence to Bonner's Ferry); and a silt and sand based reach that is diked and has a regulated hydrograph (Deep Creek to Shortie's Island). The minor study reaches provide data on areas where some natural ecological function is occurring in the Bonner's Ferry to Kootenay Lake Reach. Photographs of each reach are included in Appendix I. 
* For subsequent discussion we have shortened the reach descriptions as below.

Wasa bridge to Cherry Creek Reach: Wasa Reach

Libby Dam to Moyie River Reach: Libby Reach

Moyie River to Bonner's Ferry Reach: Moyie Reach

Deep Creek to Shortie's Island Reach: Shortie's Island Reach

Shortie's Island to Copeland Reach: Copeland Reach

Duck Lake to Kootenay Lake Reach: Kootenay Lake Reach 


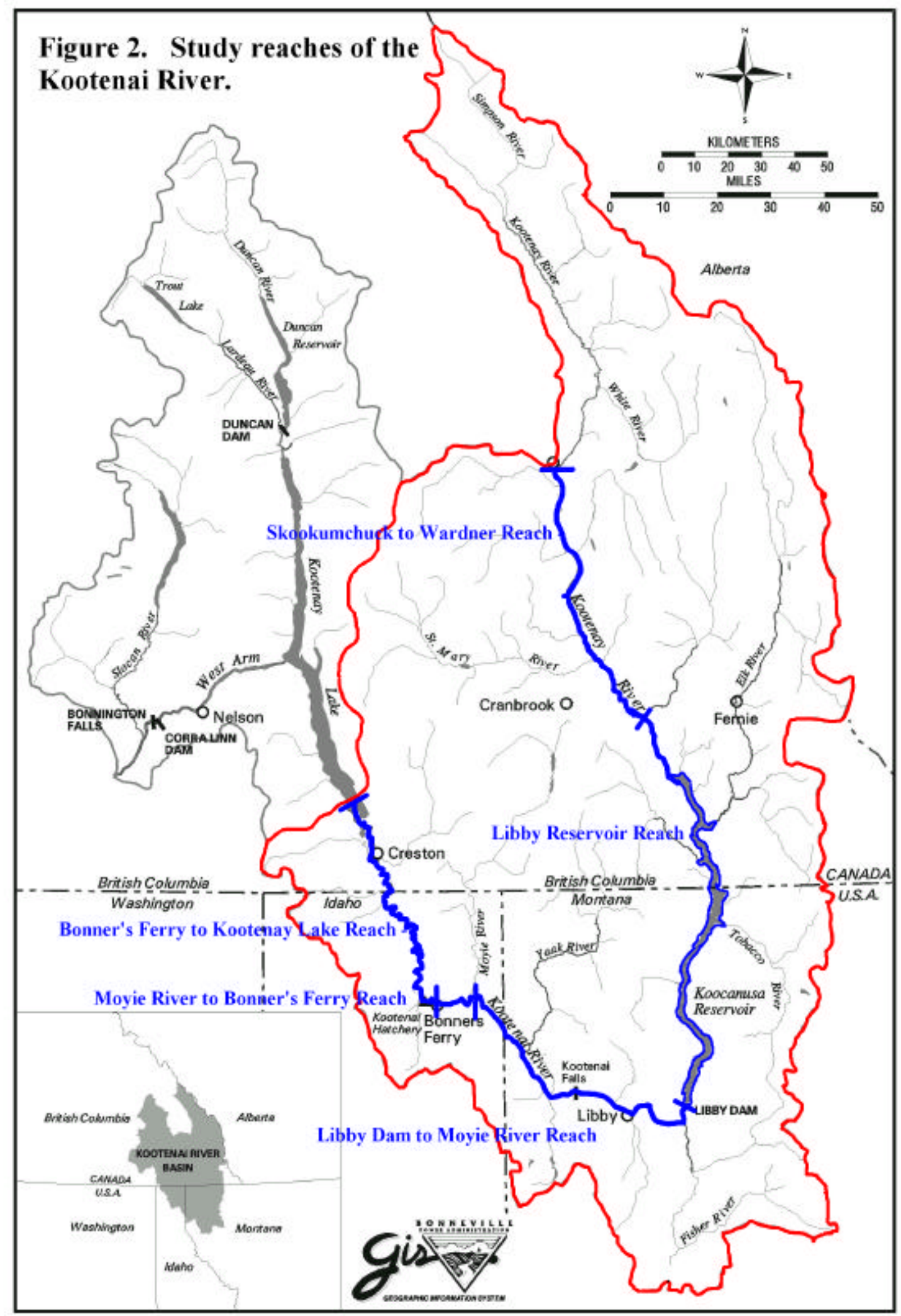

BioQuest International Consulting Ltd. 
Figure 4. The Canal Flats to Wardner Reach and the Wasa to Cherry Creek study reach.

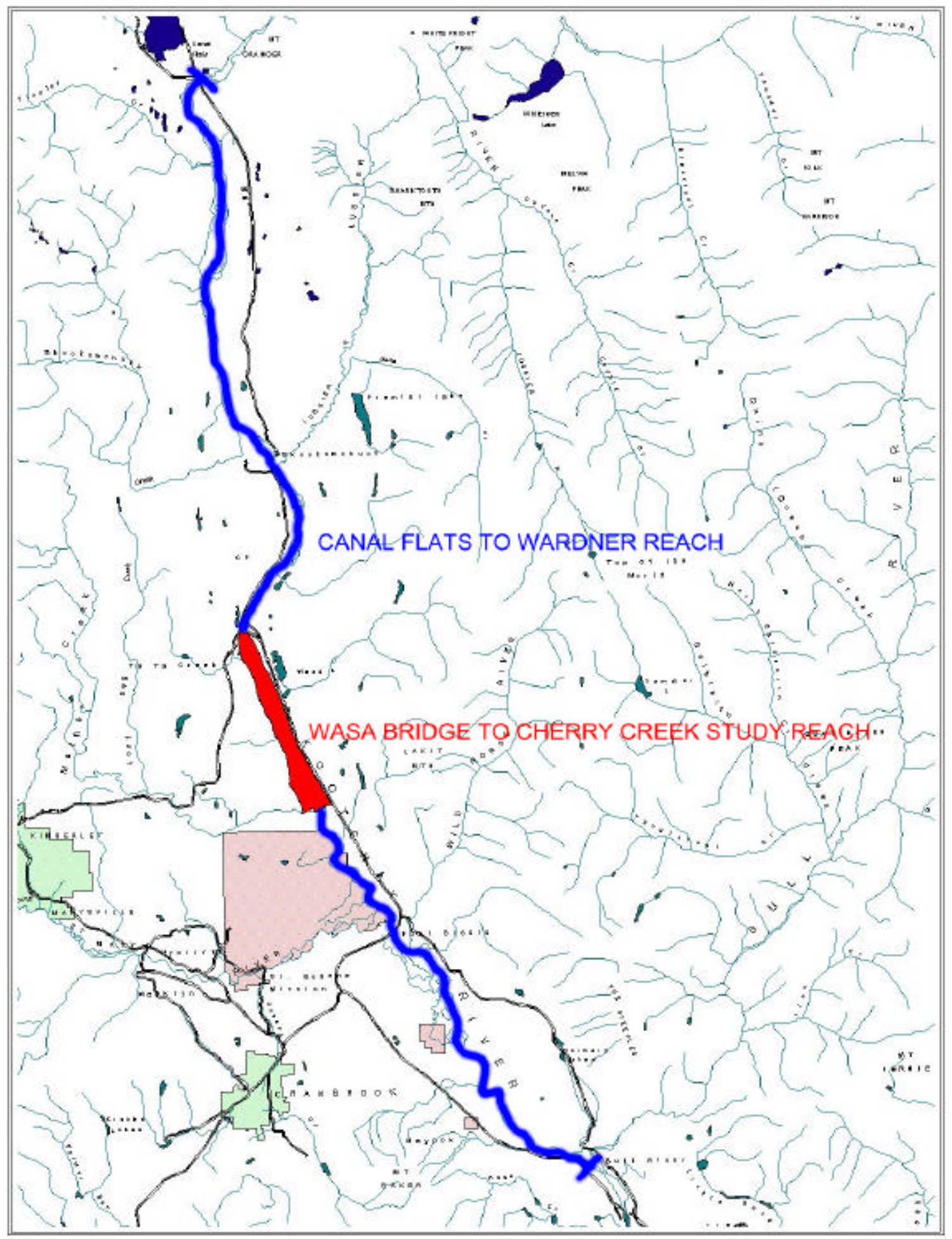


Figure 5. The Moyie confluence to Bonner's Ferry reach and the US portion of the Bonner's Ferry to Kootenay Lake Reach.

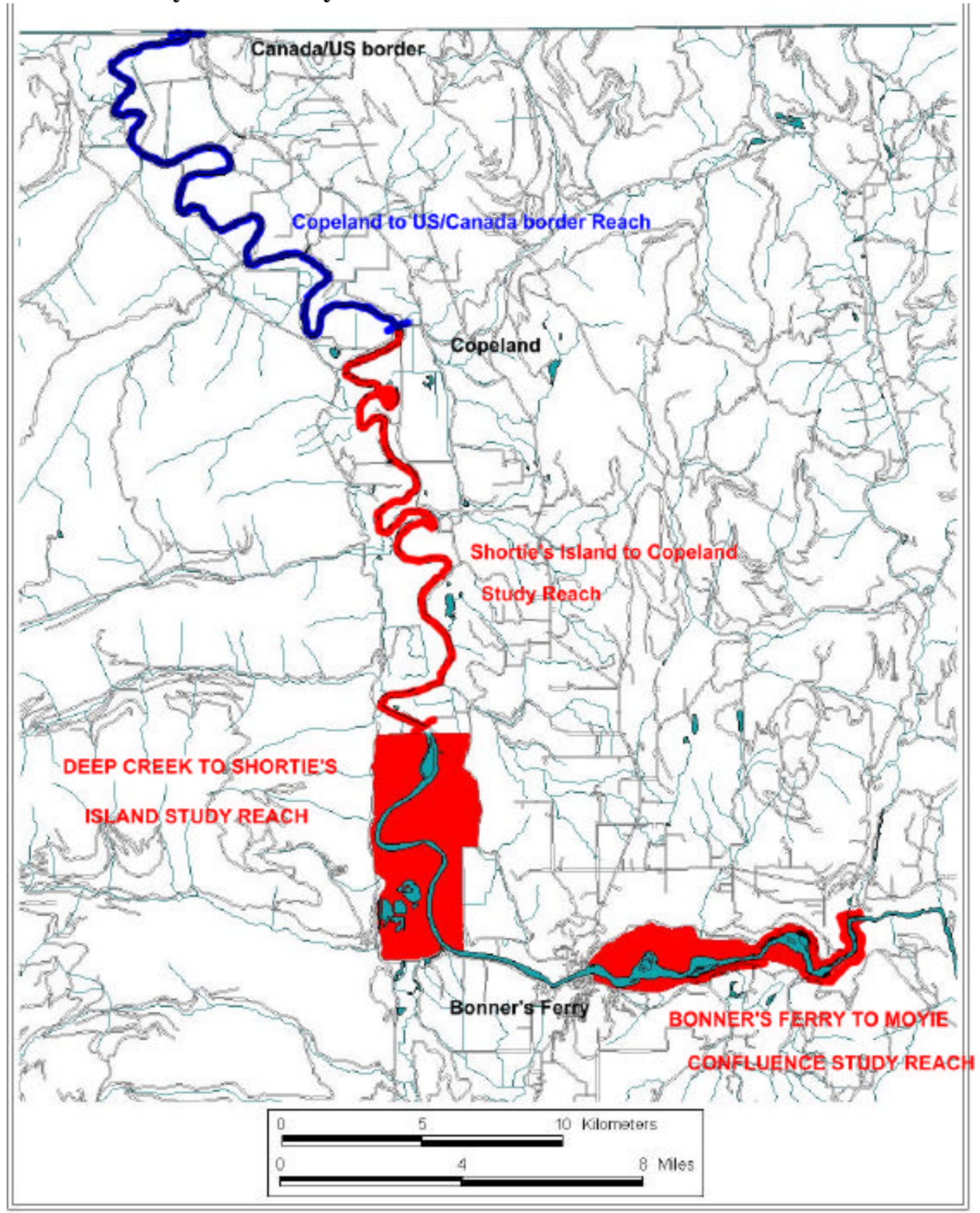


Figure 6. The Canadian portion of the Bonner's Ferry to Kootenay Lake Reach.

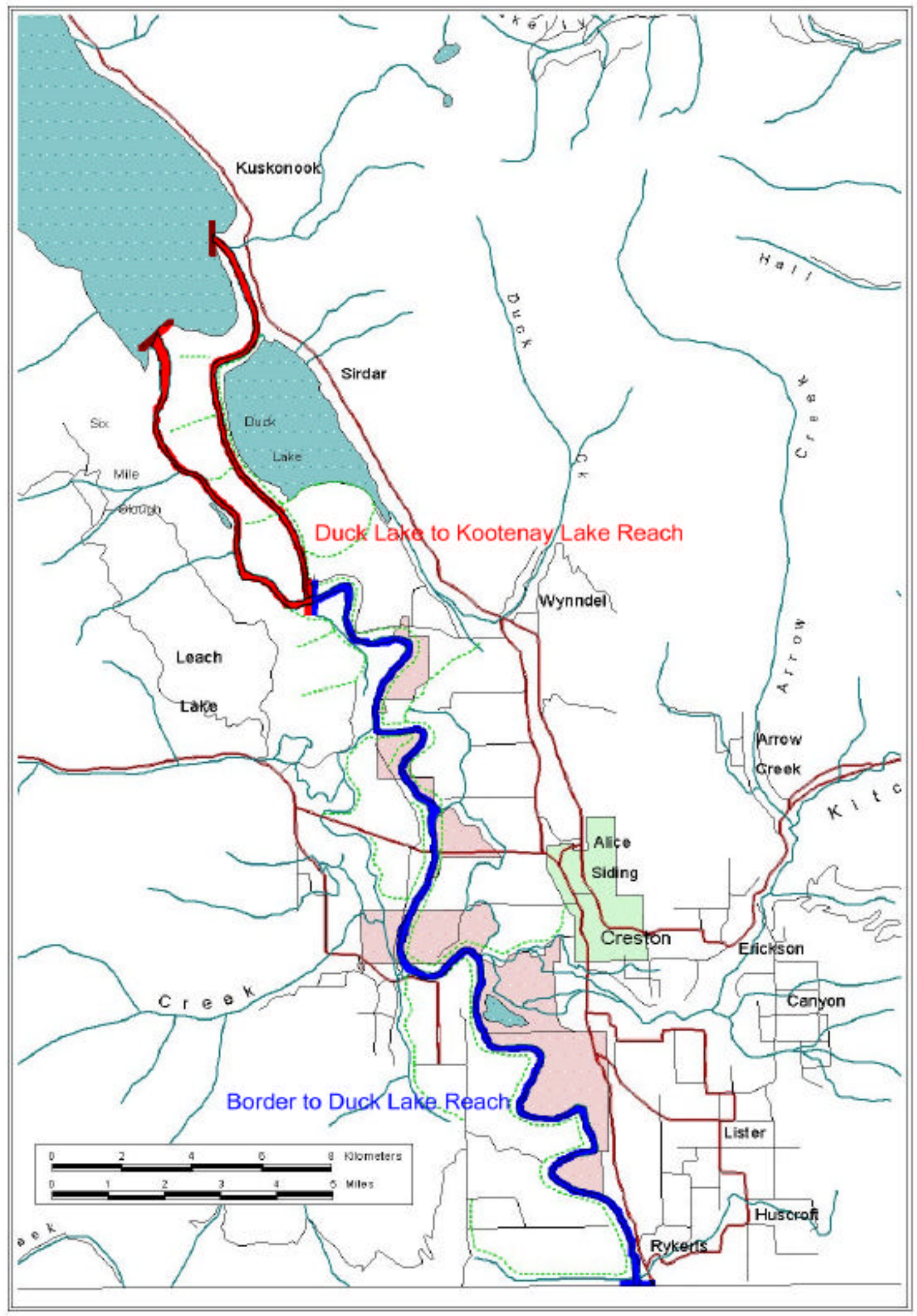




\subsection{METHODS}

We looked at study reaches in two major alluvial reaches below Libby dam and one upstream of the dam. The upstream reach was studied to provide a sense of riverine processes on an unregulated portion of the river. We provide data on one $13.9 \times 1.8 \mathrm{~km}$ study reach (Wasa to Cherry Creek) within that larger reach (approximately $120 \mathrm{~km}$ ). The two downstream reaches were studied to look at the impacts of flow regulation on riparian cottonwood stands. The Moyie to Bonner's Ferry reach was treated as a study reach in its entirety $(10.0 \times 2.5 \mathrm{~km})$. One study reach (Deep Creek to Shortie's Island $(10.0 \times 5.0 \mathrm{~km})$ was established within the Bonner's Ferry to Kootenay Lake reach $(82.5$ $\mathrm{km})$. Secondary study reaches were established upstream of the Copeland Bridge and at the outflow of the river into Kootenay Lake. Transect data only was collected in these reaches.

The methods used are described below by objective and task.

\section{OBJECTIVE 1: Provide a general overview of the status of the major alluvial floodplains of the Upper Kootenai River prior to 1930.}

We looked at the historic record to document pre-settlement and pre-air photo circumstances on the river. Libraries and information at museums were searched for photos and text describing those conditions. Long time residents and resource managers were consulted.

OBJECTIVE 2: Provide an assessment of the status of riparian cottonwood stands and related riparian habitat types on alluvial floodplains on the Upper Kootenai River prior to the construction of the Libby dam in 1968-72.

Task 2a: Document changes in riparian vegetation on sample reaches in alluvial floodplain reaches upstream and downstream of the Libby dam, by comparing historic and recent air photos.

For the study reach upstream of the Libby dam, BC provincial government air photos for the Wasa study reach were collected and ortho-rectified for the years 1954, 1968 and 1994. (Earlier photos were not available). Ortho-rectified air photo mosaics, acquired from the United States Geological Survey (USGS), based on 1991 photos, were used as a base for study reaches in the Bonner's Ferry area. Air photos from the USFS office in Bonner's Ferry, for the Moyie and Shortie's Island reach for 1934 and 1968 were orthorectified and fitted to the 1991 air photo mosaics using a GIS system. 
We identified the following landforms and riparian vegetation types in these sample reaches.

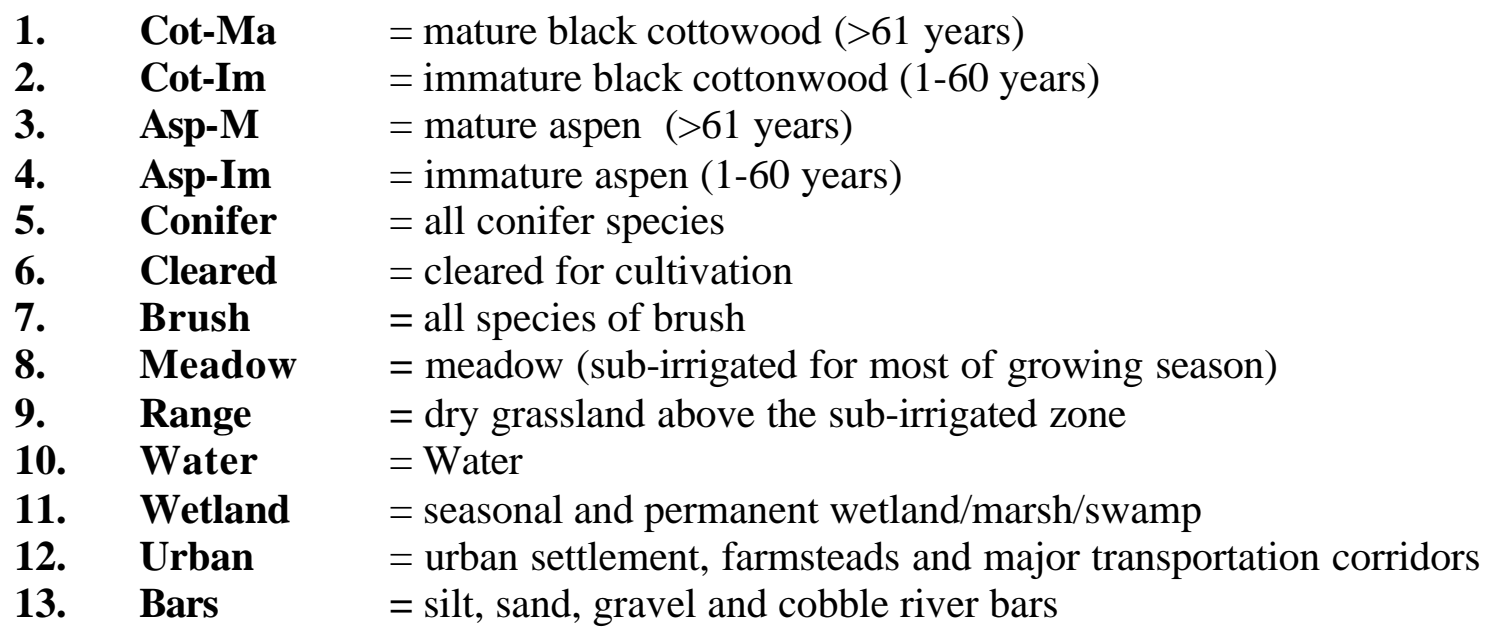

Habitat units were typed by hand on printed copies of the ortho-mosiacs (1:10,000 scale). Field checks were used to verify the typing for mapping from the most recent era (1991 and 1994). On the Canadian study reach, the typing was compared to BC Forest Service Forest Cover mapping to provide guidance on stand ages. The typing for the 1990's era mapping was more detailed than that for previous eras. Resolution for the 1991 and 1994 mosiacs is approximately $1 \mathrm{~m}$. We found that we could locate, with field checks, stands and habitat types down to approximately .5 ha or one acre in area. We did not attempt to type units $>5$ ha ( 2 acres) in the earlier mapping. The habitat typing was completed by hand and then transferred to a GIS system using a data plotter. Image processing was completed using PCI Works 6.2, CorelDraw 8 and Ghostview 3.4. Analysis was carried out using Arcview 3.1 and ArcInfo 7.2.

\section{OBJECTIVE 3: Document the present distribution of riparian cottonwood stands in the major alluvial floodplains of the Kootenai River.}

Task 3a: Provide mapping of the present distribution of riparian cottonwood stands in three study reaches of the Kootenai River.

The ortho-rectified mosaics for 1991 and 1994 were used to define the distribution of cottonwoods in each study reach, based on the methods described above. As a separate part of this study, we compared mapping and data from several different remote imagery tools. Air photo mosaics, Landsat 5 and B.C. Forest Cover mapping were tested in the Kootenai sub-basin; air photo mosaics, Landsat 7, IKONOS and ADAR were tested in the Yakima sub-basin (see Tools Report). 


\section{OBJECTIVE 4: Document stand health and recruitment to riparian cottonwood stands and related riparian habitat types in the major alluvial floodplains of the Kootenai River.}

\section{Task 4a: Document stand health and recruitment to riparian cottonwood stands and related riparian habitat types in three study reaches in the Upper Kootenai sub- basin using vegetation transects.}

We studied the health and recruitment to cottonwood stands and associated riparian vegetation types according the protocols described below. Transects were established on point bars where site conditions that would be the most conducive to the recruitment of cottonwood seedlings. In most cases two sets of transects were established on a single large point bar. Transects were distributed as below:

Wasa to Cherry Creek study reach Moyie confluence to Bonner's Ferry study reach Deep Creek to Shortie's Island study reach Trout Creek to Copeland study reach Duck Lake to Kootenay Lake study reach

\author{
15 transects \\ 5 transects \\ 4 transects \\ 4 transects \\ 5 transects
}

The transects were established perpendicular to the river edge and extended up through the different zones of riparian vegetation to upland habitats. The length of these transects ranged from 15 to $110 \mathrm{~m}$. In grass and forb dominated communities, plant frequency and cover was sampled using $1 \mathrm{~m} \times 1 \mathrm{~m}$ quadrats placed at $1 \mathrm{~m}$ intervals. Percent coverage was estimated for all species. Coverage classes were converted to an octave scale for purposes of data analysis. Larger quadrats were used to sample communities dominated by shrubs ( $2 \mathrm{~m} \times 4 \mathrm{~m}$ quadrats) and trees ( $5 \mathrm{~m} \times 20 \mathrm{~m}$ quadrats). Sampling of trees and shrubs included stem counts, diameter at breast height (dbh) and age class determinations for dominant woody species. Quadrats were classified according to their position along the elevation/inundation gradient of riverbanks (i.e. barren streamside zone, obligate riparian zone, facultative/transitional riparian zone and upland zone). These methods for quantifying relative abundance and plant community properties follow the sampling protocols of Mueller-Dubois and Ellenburg (1974), Goldsmith et al. (1986), Johnson et al. (1987, 1992, 1995), Scott et al. (1993), and Auble et al. (1994).

A surveyor's sight level was used to determine the relative elevation of each sample quadrat along the transect. This data also allowed us to develop an elevational profile of the river bank at each transect location. This data also allowed us to determine the relationships between the vertical distribution of plants and seasonal and historic water levels. A pin was inserted at the water level and elevations were recorded in $1 \mathrm{~cm}$ increments along a tape running perpendicular to the river. A temporary benchmark (a metal tag attached to a large tree) was positioned at the uppermost end of each transect. GPS coordinates (Trimble ProXRS) of this benchmark, the high scour line, and upper and lower ends of the transect were recorded. 
We linked our field elevation data to actual elevations (meters above sea level) through the following process:

For the Wasa bridge to Fort Steele study reach we constructed stage/discharge regression equations to estimate transect elevations based upon: a) water surface measurements throughout the 2000 growing season at several bridge crossings, b) known elevations and discharge parameters for gauges located upstream and downstream of our study sites, c) topographic maps to estimate average river gradient and distance between study transects. In the Lower Kootenai study reaches we used published estimates of river gradient from Snyder and Minshall 1996 and know elevations at the gauge at Bonner's Ferry. For the transects located at Kootenay Lake we used the elevation of the lake on the day of the transect to establish the elevation at the base of the transects.

Surface substrates were classified as: 1) fine - fine sediment (sand, silt, or clay, 2) finecobble - coarse material surface (gravel, cobbles, small boulders) with a subsurface of fines just below the coarse surface material, 3) cobble - coarse surface material without fines below the surface layer, 4) bedrock. A visual classification was recorded for each quadrat. A photograph, using a grid, was taken at the upper, lower, and middle areas of each transect along with the visual classification of the substrate at these three locations.

Vertical distribution patterns were analyzed using direct gradient analysis. Graphs were drawn showing the distribution and occurrence of different plant species by elevation. In these graphs, elevations are presented relative to long-term base flow elevations during the growing season. At Fort Steele base flow was calculated from average daily flows for September for 1928 to 1998 and then converted to elevations at Fort Steele and then to the transect locations using the river gradient data. September stage data for the post dam (1975 to 1990) era was used to establish base flows at Bonner's Ferry and at each transect location. For the transects at Kootenay Lake we used an estimate of low pool for Kootenai Lake (regulated by the Cora Linn dam).

Long-term base flow elevations for the Upper Kootenai were .31 to $.45 \mathrm{~m}$ below the water levels on the days of the transects, thus all values are positive on the graphs. Due to the regulated flow regime along the Lower Kootenai, the long-term base flows in September were above the levels on the days of the transect, thus there are many negative values on the graphs for that area. Elevations on the days on which the transects were established were $0.45 \mathrm{~m}$ to $0.55 \mathrm{~m}$ below long-term base flow elevations. 
OBJECTIVE 5: Document the pre and post-dam seasonal flow regime of the Kootenai River.

Task 5a: Document the seasonal hydrograph on the Kootenai River upstream of Libby Dam.

We used the "Hydat" data base maintained by the federal Department of Environment for information on flows at Fort Steele. Data was available for the years 1928 to 1998. There were minor data gaps in some years.

Task 5b: Document the seasonal hydrograph on the Kootenai River downstream of Libby Dam, prior to and following the construction of the dam.

We used databases on water flows maintained by the United States Geological Survey (USGS). Recording stations are located at Libby dam, Bonner's Ferry and Porthill (at the US-Canada border). We used this data to develop hydrographs for 10 year periods at Libby and Porthill, prior to and following construction of the Libby dam and the initiation of flow manipulation with the completion of the dam. The dam was completed in 1972. Partial flow manipulations occurred in 1973 and 1974 as the dam filled. Full control and manipulation of flows for producing power occurred from 1975 to 1990. In 1991 experimental spring releases were tested as part of the Kootenai white sturgeon recovery program. Stage data for Bonner's Ferry was therefore calculated for 1963 to 1971, from 1975 to 1990 and from 1991-2000.

OBJECTIVE 6: Document the relationship between seasonal flow regimes and cottonwood abundance and stand health.

We carried out a literature search and utilized the extensive knowledge of the team members on this issue. We also talked with other researchers in this area and dam operators in other areas where releases for cottonwood recruitment are being tested and documented, primarily in Alberta and Nevada.

OBJECTIVE 7: Document flow management options to maintain riparian cottonwood habitats below Libby Reservoir.

Task 7a: Apply our understanding of cottonwood ecology and river dynamics to define options for using manipulated flows to re-establish cottonwood recruitment below Libby dam.

Using the data collected in this study and applying the models developed elsewhere, we developed strategies for manipulating flows in this system to benefit cottonwood stands and other riparian plant communities, based on the "recruitment box" concept developed by Mahoney and Rood (1998). We also had extensive discussions with the researchers and managers already working with managed flows in relation to white sturgeon, bull 
trout and burbot (ling cod) in the Kootenai system. The Biological Opinion: Effects to Listed Species from Operations of the Federal Columbia River Power System (USFWS 2000) was a major source of our understanding of the way in which flows will be managed in the next decade.

\subsection{STUDY TEAM}

The major authors of the study were Bob Jamieson and Dr. Jeffrey Braatne. Doug Connery managed the GIS and data acquisition portion of the project on the Kootenai River. We also utilized four botanists with expertise on cottonwoods and other riparian plant species for the field data collection portion of the study. They were: Mary Louise Polzin, a PhD candidate at the University of Montana, Greg Allen, a consulting botanist, Cranbrook, B.C., Dr. Clint Smyth, a consulting botanist, Blairmore, Alberta and Kathy Metzler, a research technician at the University of Lethbridge, Alberta.

Portions of the project were carried out by sub-contracts. Geosense Ltd., a GIS firm in Nelson, B.C. ortho-rectified the air photos used. Tom Phillips of Eagle Vision Ltd. in Cranbrook, B.C. carried out the analysis of the air photo mosiacs. An analysis of BC forest cover data, looking at aspen, birch and cottonwood for the Canadian portion of the Basin, was carried out by Ian Parfitt, GIS coordinator for the Columbia Basin Fish and Wildlife Compensation Program (CBFWCP), as part of project looking at the status of hardwoods in the Canadian portion of the Columbia Basin (Jamieson et al. 2001). This mapping was made available to this project by the CBFWCP.

Dr. Jack A. Stanford, Director of the Flathead Lake Biological Station, Dr. Stewart Rood of the Department of Biology, University of Lethbridge and Dr. Mike Merigliano of the University of Montana provided technical overview on the project. 


\subsection{RESULTS}

We have presented the results of this study by reach, beginning upstream of the Libby dam and proceeding downstream to Kootenay Lake. A general description is provided for each major alluvial reach on the mainstem Kootenai River. Data and mapping is then presented for each of the study reaches nested within each of these larger alluvial reaches. Short descriptions of the major non-alluvial reaches are included to provide some continuity and give the reader an overall sense of the status of the entire river system.

\subsection{SKOOKUMCHUCK TO WARDNER REACH}

\subsubsection{EARLY HISTORY}

This area was important to the Ktunaxa people as a hunting and fishing area, although there were no salmon in the Kootenai River (W. Chouquette, pers. comm.). The first recorded white contact in this portion of the basin occurred in April of 1808 when David Thompson traversed this portion of the river on his way to the Bonner's Ferry area (Nisbet 1994). The first significant influx on Europeans occurred with the gold strike at the Wildhorse River in 1863 (Scott and Hanic 1979). Hydralic mining was used in the 1890 's and early 1900's. This activity may have altered sediment loads lower on the Kootenai River downstream of this tributary. A lead-zinc mine, the Sullivan, at Kimberley, resulted in water quality impacts in the St. Mary's River and Kootenai River that lasted into recent decades. Early in the 1900's, logging occurred through much of the Rocky Mountain Trench. Very large wild fires in the 1910's to 1930's burned both the Trench and extensive areas in the St. Mary's, Findlay, Upper Kootenai and Elk Rivers and may have resulted in erosion that may have resulted in widespread erosion and sediment deposition in river system. Coal mining in the Elk valley began early in the century, but shifted from underground to open pit operations only in recent decades. Cattle use was minimal with wild ungulates and wild horses being the major graziers up to 1950. Cattle and ungulate numbers reached historic highs in the 1960's (R. Demarchi, pers. comm.) but the degree to which these numbers affected riparian areas along the Kootenai River is not known. Settlement on the floodplain along this portion of the Kootenai River was slow to develop and occurred much later than downstream in the Bonner's Ferry and Creston areas. The regular flood events on the river limited attempts at cultivation; however, by the 1950's, several ranches were established along the river. There were no attempts to grow cereal crops. The major agricultural impact has been the clearing of land for hay production. 


\subsubsection{PRESENT SUB-BASIN STATUS OF COTTONWOOD STANDS.}

Cottonwoods stands are presently distributed throughout the Kootenai sub-basin on riparian sites and some upland sites. Jamieson et al. 2001 provides mapping of cottonwood distribution throughout the Canadian portion of the sub-basin (available on the Col. Basin Fish and Wildlife Compensation Program website at www.cbfishwildlife.org). Riparian cottonwood stands occur along the major tributaries of the Kootenai (Elk, St. Mary's Rivers) and along the Kootenai throughout the Canal Flats to Wardner Reach. They occur in upland situations in only a few areas where moist soil conditions are found.

\subsubsection{PRE AND POST DAM HYDROGRAPHS.}

This portion of the Kootenai River has a natural and seasonally dynamic hydrograph since there are no upstream dams. High flows have averaged from 1200-1500 cms except for 1933, 1948, 1956, 1961 and1974 when spring rain storms coincided with snow melt and flows exceeded $1600 \mathrm{cms}$. The highest flows $(1820 \mathrm{cms})$ were recoded in 1947. Low flows generally occur in January and are in the $20-30 \mathrm{cms}$ range. 
Figure 7. Annual Hydrograph at Fort Steele, 1964-1990.

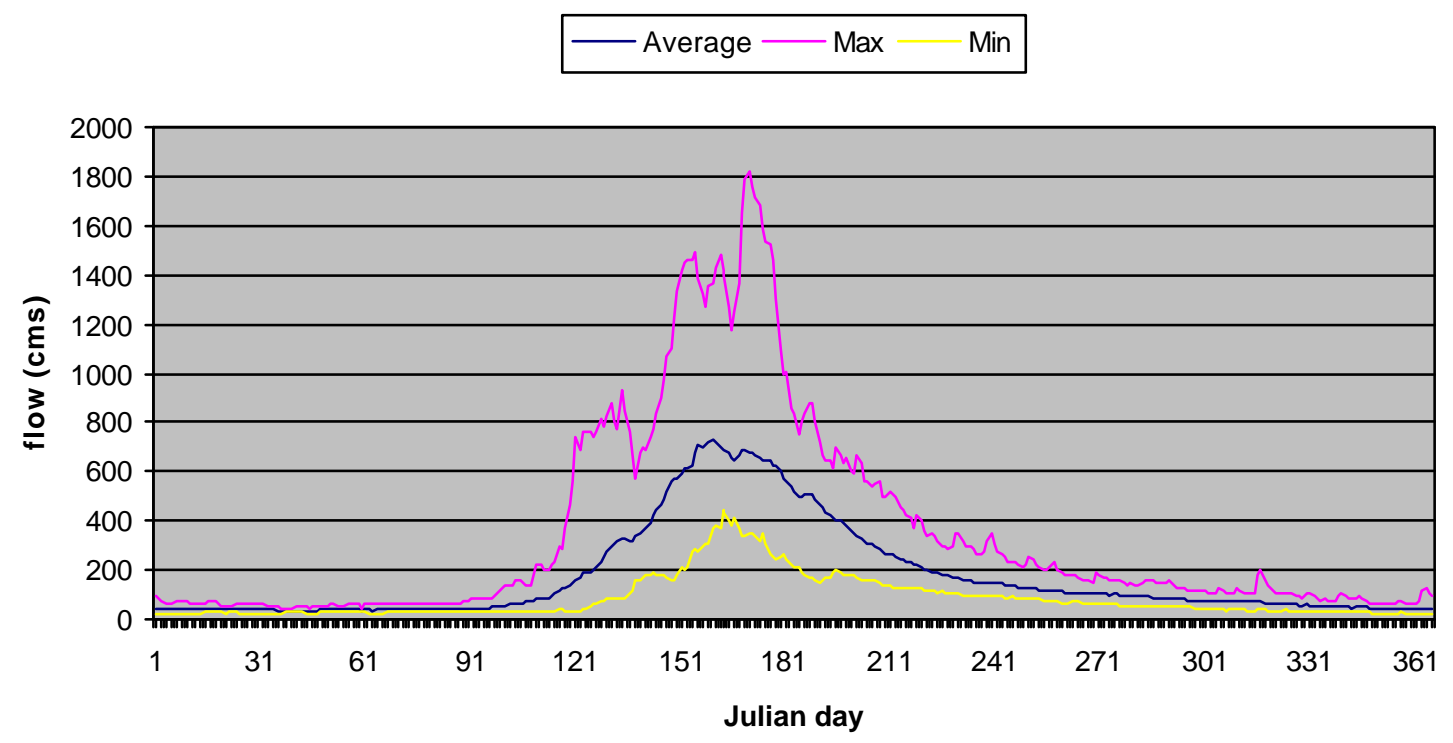

Figure 8. Flow at Fort Steele, 1991-1997.

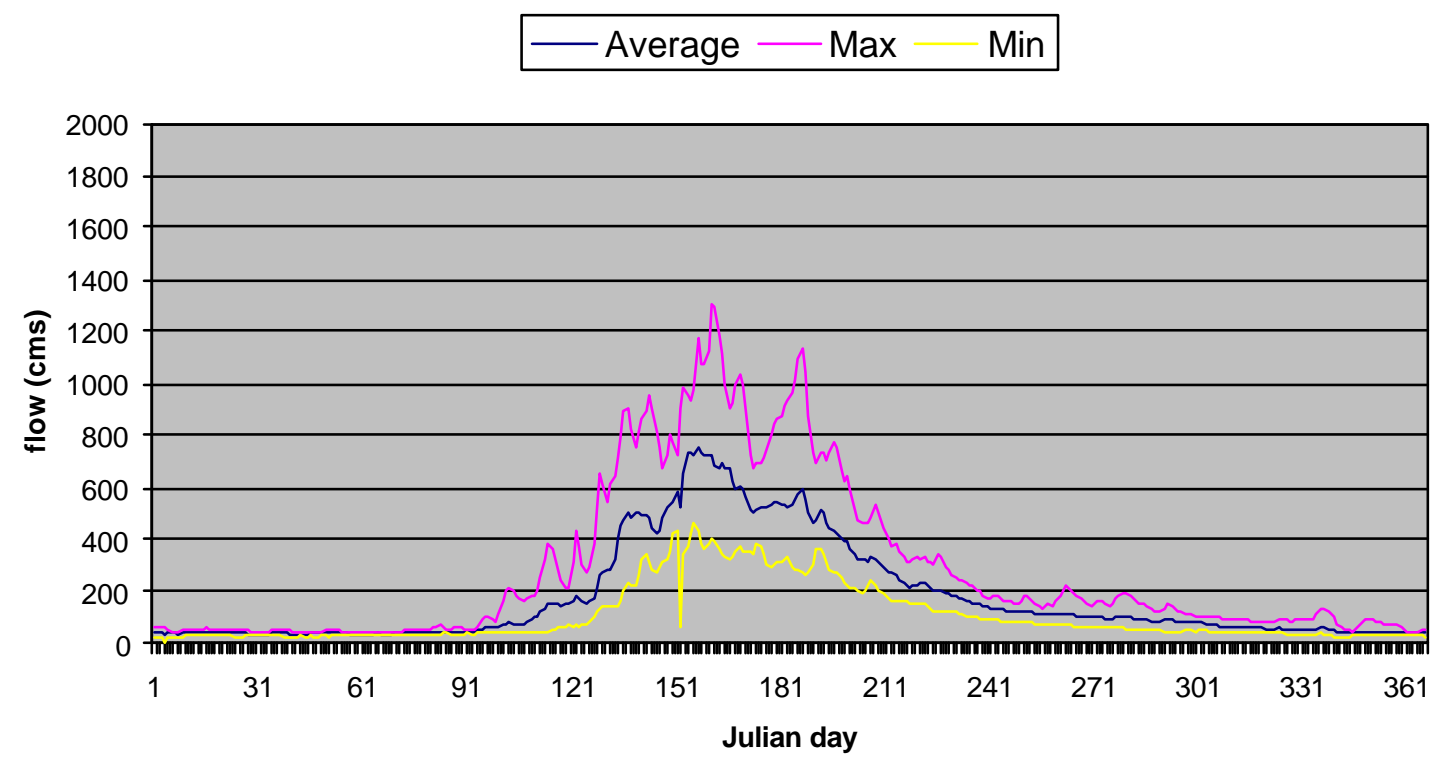




\subsubsection{WASA BRIDGE TO CHERRY CREEK STUDY REACH.}

This study reach (15 km long) is a meandering single channel with sand and silt-based substrates . The gradient of the river is low $(0.21 \mathrm{~m} / \mathrm{km})$. The floodplain varies from 0.5 to $2.0 \mathrm{~km}$ in width and supports a mix of riparian forest, wetland, meadow and grassland habitats. Photographs of this reach are provided in Appendix I.

\subsubsection{Riparian Habitat Change in recent decades.}

There have been significant changes in this reach as a result of both natural processes and human activities over the last several decades. We looked at the historic impacts of human activity from 1952 to 1994, using air photo interpretation. Figure 4 shows the habitat types found in this study reach in 1952, 1968 and 1994. Table 1 compares the area of each habitat type in each year.

Table 1. The area (ha) of different habitat type in the Wasa to Cherry Creek reach in 1952, 1968 and 1994.

\begin{tabular}{|lrrr|}
\hline Habitat Type & 1952-ha. & 1968-ha. & 1994-ha. \\
\hline Cottonwood & 72.86 & 72.43 & 72.18 \\
\hline Aspen-Mature & 2.31 & 609.48 & 558.92 \\
\hline Aspen-Immature & 627.01 & 0 & 0 \\
\hline Conifer & 70.18 & 70.18 & 70.18 \\
\hline Cleared & 50.82 & 110.29 & 200.62 \\
\hline Brush & 54.14 & 54.14 & 54.14 \\
\hline Meadow & 395.98 & 357.41 & 335.92 \\
\hline Range & 99.86 & 99.86 & 79.93 \\
\hline Water and bar & 259.47 & 259.47 & 259.47 \\
\hline Wetland & 72.86 & 72.86 & 72.86 \\
\hline Urban & 2.4 & 2.9 & 4.82 \\
\hline & & & \\
\hline TOTAL & 1707.89 & 1709.02 & 1709.04 \\
\hline
\end{tabular}


Figure 9. Habitat mapping for the Wasa to Cherry Creek study reach in 1952.

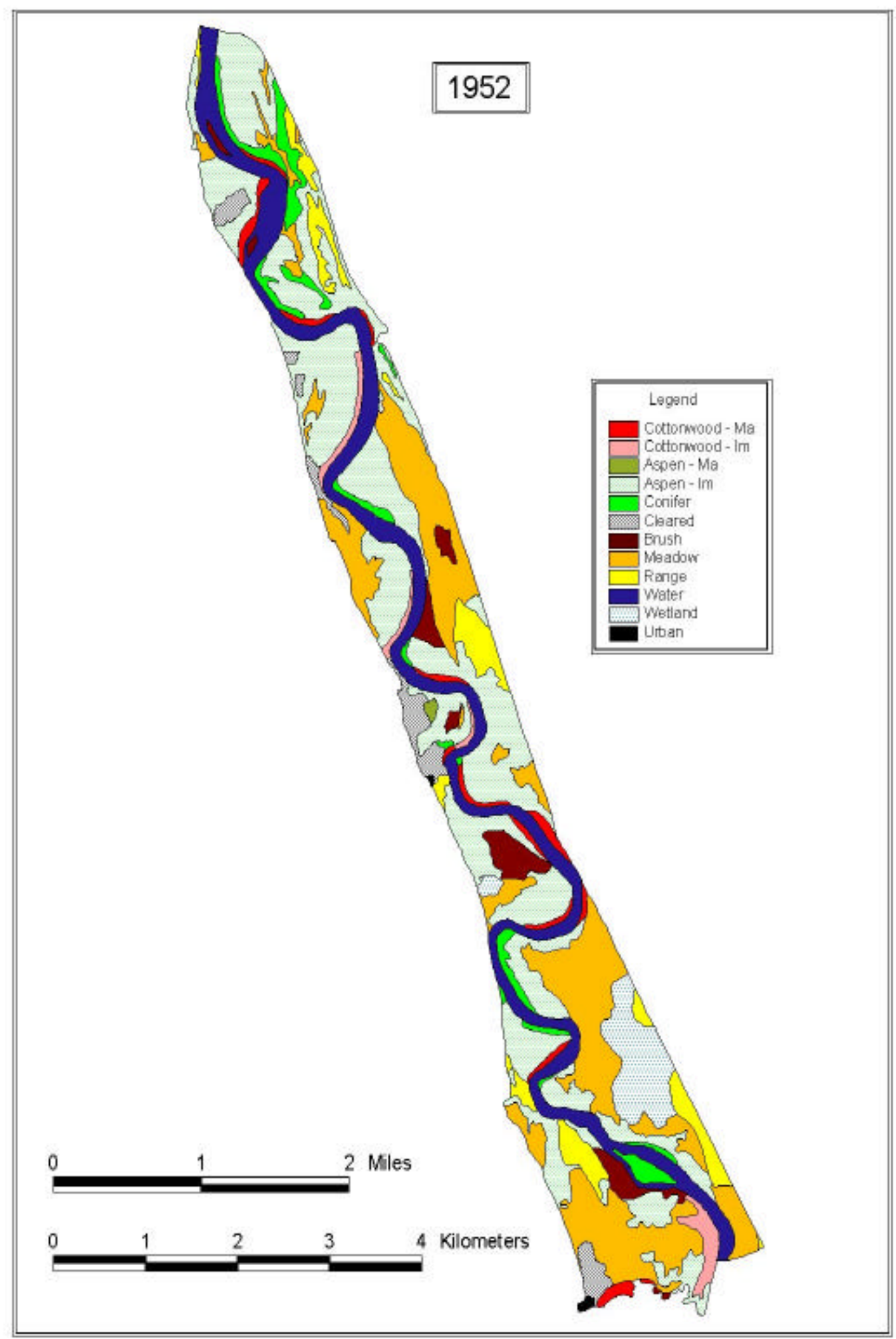


Figure 10. Habitat mapping for the Wasa to Cherry Creek study reach in 1968.

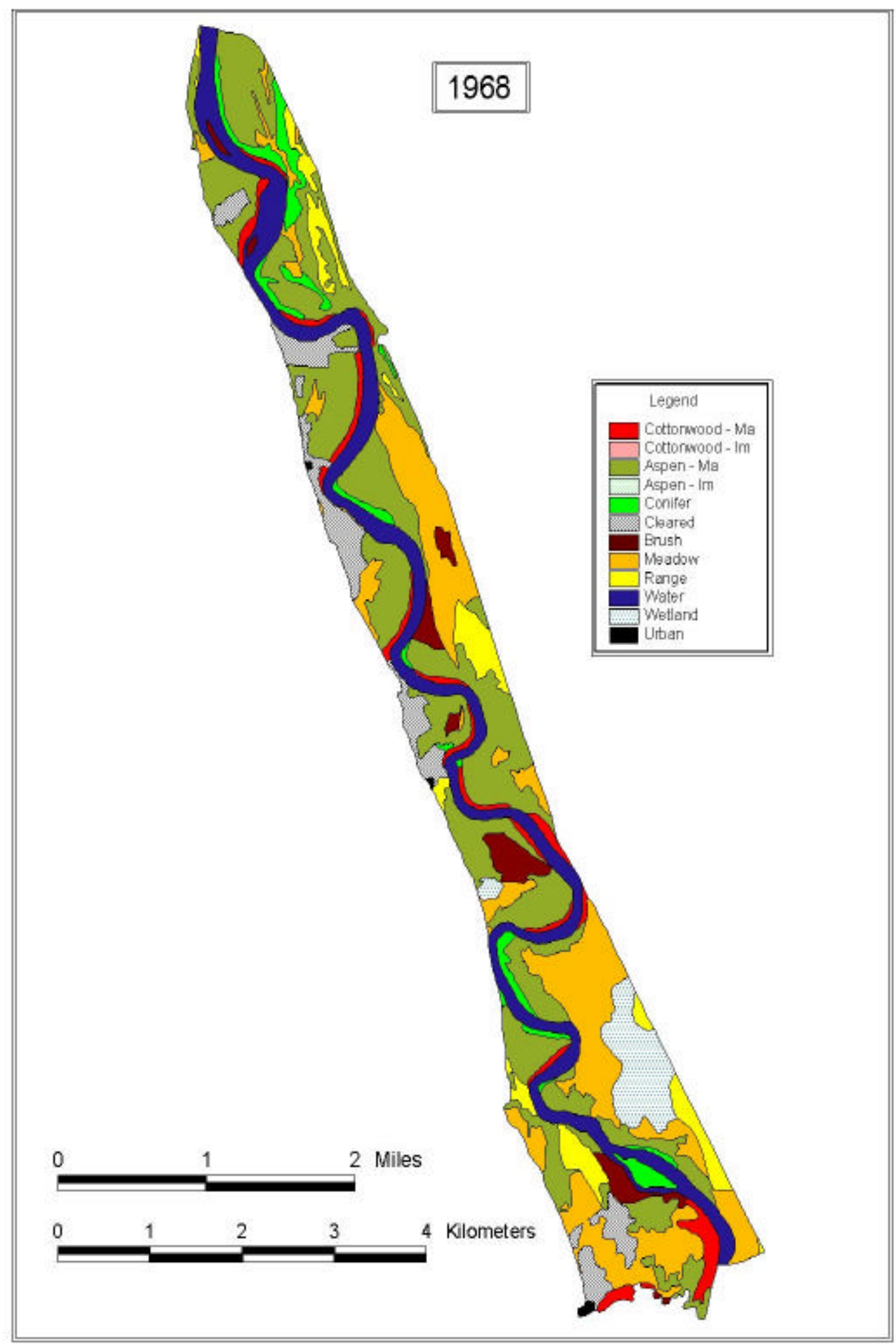


Figure 11. Habitat mapping for the Wasa to Cherry Creek study reach in 1994.

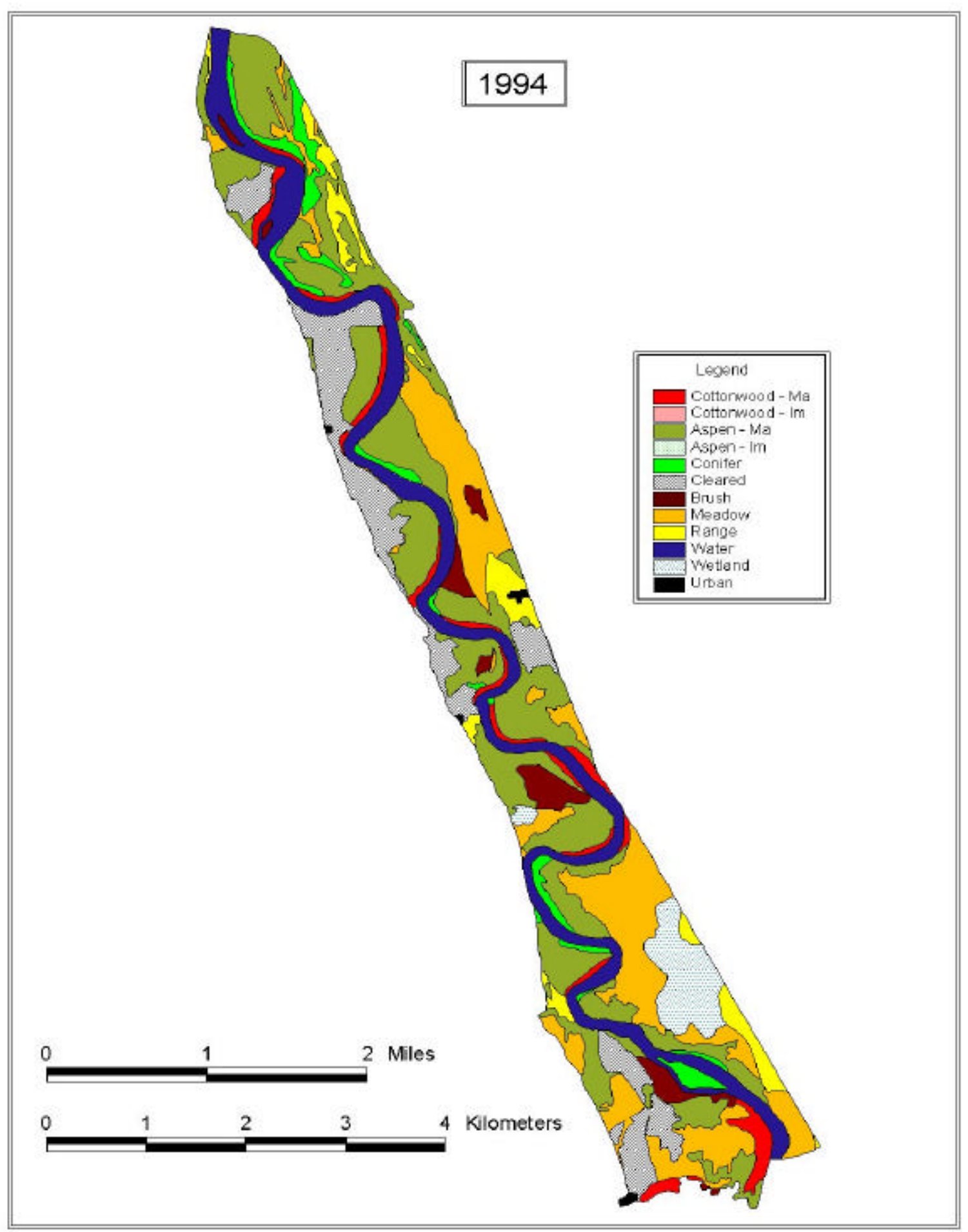


This analysis indicated that:

- Cottonwood stands in this reach consist of long, narrow stands along the riverbanks, generally adjacent to point bars. These stands have been present on the same sites for the 42 year period we looked at.

- Aspen stands are common on the floodplain area in this reach. They probably date from fires in the 1930's. There were extensive fires in this area in the 1930's that burned some parts of the floodplain (Lister Canning, pers. comm.). No fires have occurred in the floodplain area since the 1950's (J. Brown, pers. comm.). Aspen stands show recruitment by root suckering in many stands with multiple age classes present. There is also some expansion of younger stems into adjacent habitat types. The older stems are now approaching decadence. Most stands appear to be stunted to some degree by soil and flooding conditions.

- Conifer stands consisting of white spruce and Douglas fir are found on the elevated portions of the floodplain. The aerial extent of these stands has not changed substantially over the last 42 years.

- The "cleared" category describes areas that were cleared and cultivated at least once. This description is used here (rather than "cultivated") since few of these sites have been cultivated on a regular basis. The area of cleared land increased from 50.8 ha in 1952, to 110.3 ha in 1968 to 200.6 ha in 1994 . Most clearing occurred in earlier years and generally consisted of breaking natural meadows rather than clearing cottonwood stands. Young aspen stands were cleared in one area. Most of this area was planted to hay crops that is more recent years have reverted to a mix of native and domestic grasses adapted to floodplain conditions and regular flooding (J. Brown, B. Barker, G. Madison, pers. comm.). Floods inundate the river flats once or twice a decade and make it impossible to grow alfalfa cost-effectively since inundation kills alfalfa. Given the difference in net return between the value of alfalfa hay vs grass hay production (one cut vs two in this area), there is little incentive for further land clearing. No floodplain areas have been cultivated in this area for at least 10 years.

- There were extensive areas of sub-irrigated or seasonally flooded meadows in the study reach in earlier years. Some of these areas have been converted to cleared land.

- The area of "water" in the study area has not changed over the years, indicating a relatively stable channel morphology . Erosion of banks on the upstream side of each river bend is occurring, with concurrent deposition on point bars on the downstream side of each river bend. In one case, immediately adjacent to the Jamieson ranch, $120 \mathrm{~m}$ of deposition has occurred since 1952. We did not attempt to measure silt or sand "bars" due to differences in the dates on which the air photos were taken and thus differences in river height and the extent of bars exposed.

- The Bummer's Flat area was an extensive temporal wetland area that filled with water during high water. Most of this area is now permanent wetland created by diking and water control projects developed by Ducks Unlimited. 
- There has been very little expansion of human settlement onto the floodplain.

Three farmsteads established prior to 1952 have expanded in area over the last 42 years. One site was established in more recent years and one site has been abandoned.

The major and most apparent change is the vegetation patterns is the increase in mature aspen stands, and to a lesser degree, the increase in the area of land cleared for agriculture. In general, this reach has not seen the major changes to natural habitat types that have occurred further downstream. The floodplain is a mix of private and crown (public) land. Much of the lower end of study reach (Bummer's Flats and the Cherry Creek area) is private land that is now owned by a consortium of conservation interests and is managed by the Wildlife Branch of the BC Ministry of Environment, Lands and Parks.

It should be noted that the cover-types found were much more complex than is indicated by the mapping provided here. Large areas were a complex mix of aspen, alder, small opening and individual large conifers that could not be separated effectively at this level of mapping. Most of these areas were included in the mature aspen category.

We also found that it was not possible to differentiate different stand ages of cottonwood, or aspen from air photos. We attempted to use BC Forest Cover data to assess stand age but we found that this data was also of limited value. We worked back from present day age estimates from the forest cover data to estimate stand ages in 1952. We obtained negative numbers for most stands, even though many young aspen and cottonwood stands were apparent on the 1952 air photos. In other words, present age classes for these stands under-estimate the true age of the stand by at least 10 years. Ages from tree core data are rare for deciduous stands in the forest cover data. Most of the mapping is based on height classes extrapolated from sample plots. It would appear that the data for aspen and cottonwood under-estimated stand ages significantly. We therefore were not able to differentiate younger stands (20 to 80 years) from older deciduous stands (>80 years). We also found that it was difficult to separate aspen and cottonwood without stand by stand field checks.

\subsubsection{Present distribution of cottonwood stands in the study reach.}

Cottonwoods occur along the Kootenai River in the study reach as narrow bands on each bend of the river (pale green in Figure 12). They make up $4.2 \%$ of the floodplain (72 ha). 
Figure 12. The present distribution of cottonwood stands in the Wasa Study Reach.

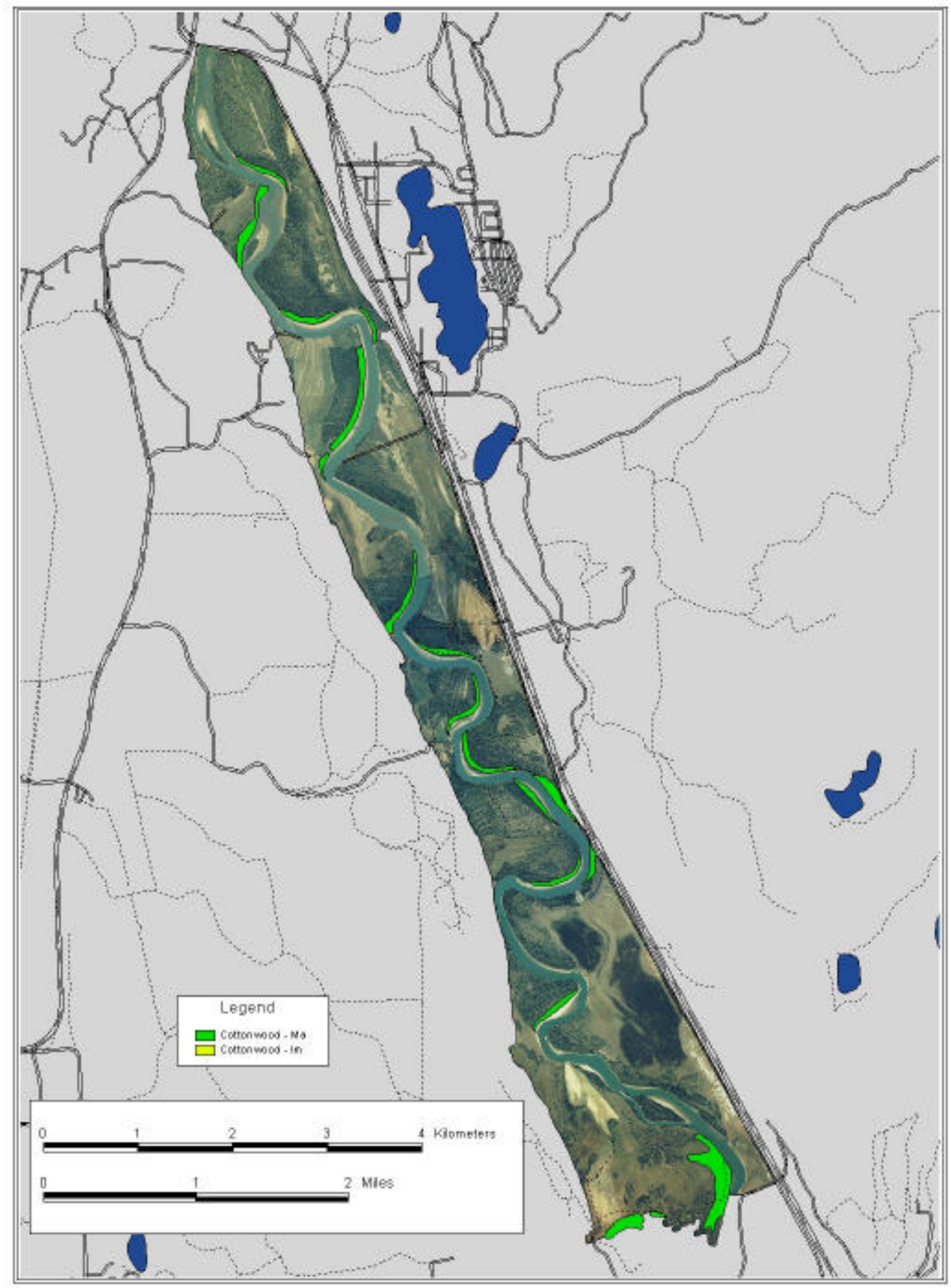




\subsubsection{River bank profiles.}

Vegetation along the Kootenai River is defined by elevation and the profile of the riverbank. We collected data on the river bank profile for the 15 transects completed in this reach. Elevation profiles for nine of these transects $(0-50 \mathrm{~m})$ is provided below. In all cases there was a gentle gradient from the water level to the adjacent cottonwood stand.

\section{Figure 13. Elevation Profiles for 9 transects in the Wasa study reach.}

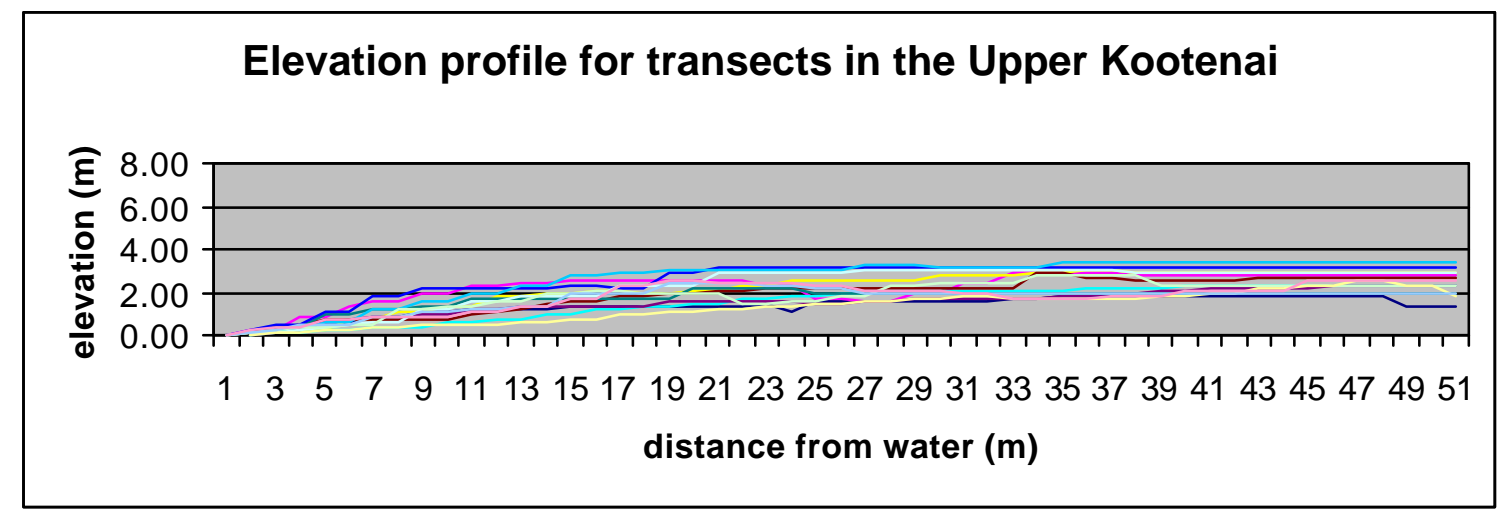

\subsubsection{River bank plant communities.}

The transect data also allowed us to document the occurrence of different plant communities. In general in this reach, the first 5-10 m of each transect length and $1 \mathrm{~m}$ of elevation was without vegetation and consisted of exposed sands and silts. Some bare ground also occurred further from the water edge, generally under shrub and tree stands. Next in elevation and distance from the river edge were grass and herb communities of varying width, and stands of young cottonwood saplings, generally mixed with willows.

We found 5 annual and 16 perennial species of grasses growing along this river reach. Grass stands were dominated by quack grass and red top (Figure 14). 
Figure 14. The distribution of grasses relative to September flows on the Wasa study reach.

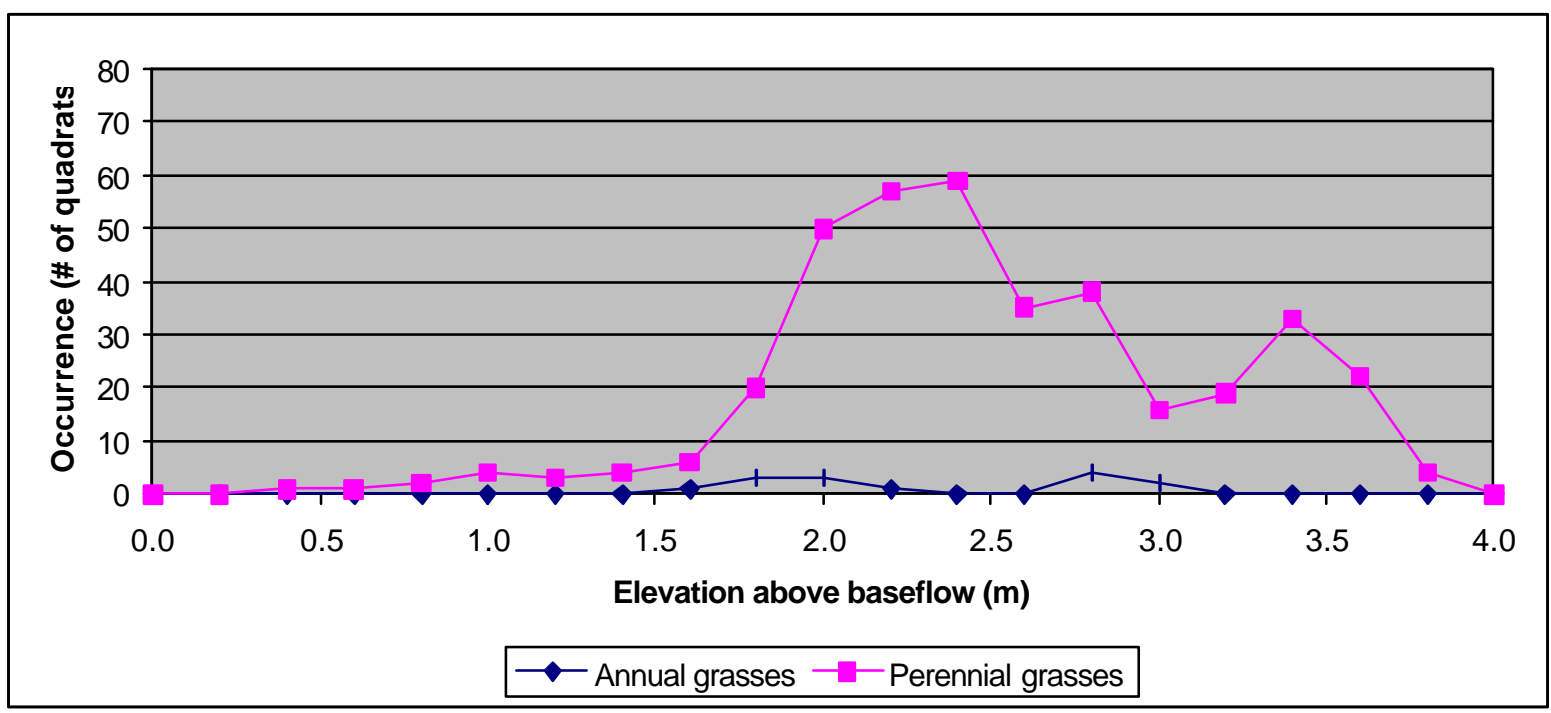

Six annual forbs, (dominated by field horsetail) and 20 perennial and biennial forbs, (dominated by three species of aster and two species of scouring rush) also occur (Figure $15)$.

Figure 15. The distribution of forbs relative to September flows on the Wasa study reach.

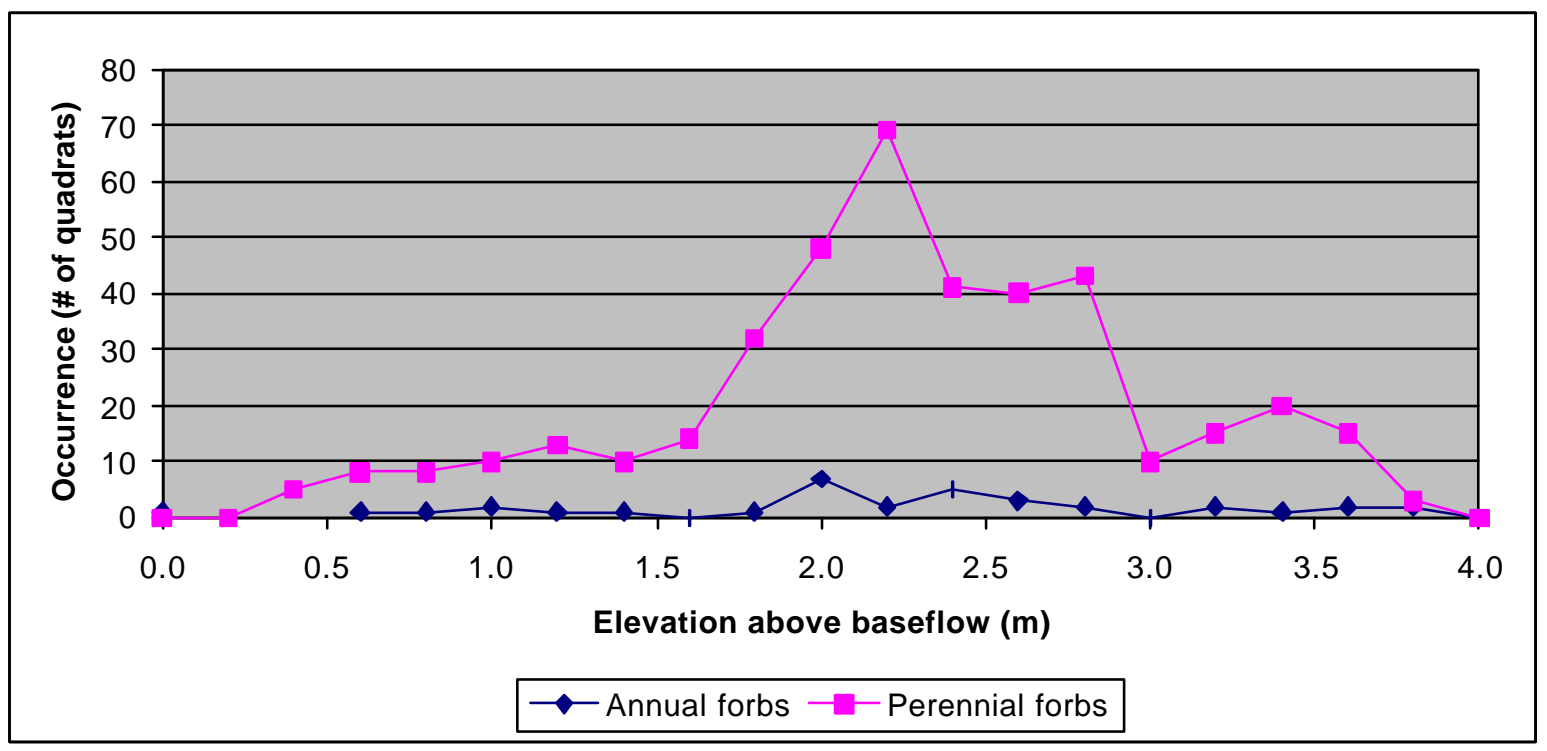


Two species of woody shrubs, (chokecherry and Wood's rose) and four species of willows were found (Figure 16). Of these, Coyote and Pacific willow were by far the most common. Dense stands of willow are a dominant feature on point bars along this reach of the river.

Figure 16. The distribution of woody shrubs relative to September flows on the Wasa study reach.

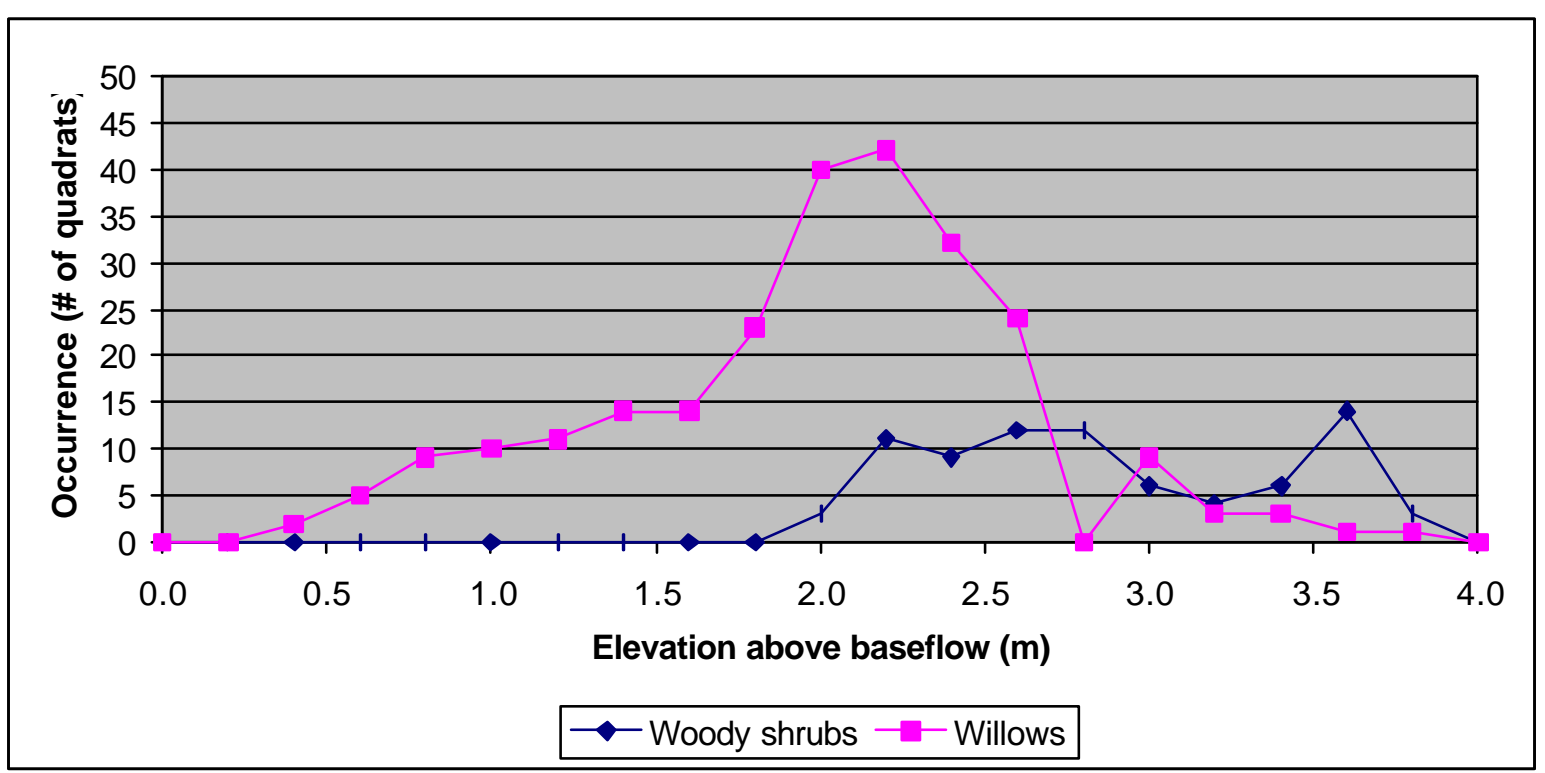




\subsubsection{The distribution of tree species by elevation.}

We found only two tree species, trembling aspen and black cottonwood, on the sample transects (Figure 17). Aspen saplings were relatively common at 1.5 to $2.5 \mathrm{~m}$ above base flows, although we recorded few mature aspen trees in the sample transects. No cottonwood seedlings were noted, but cottonwood saplings were common on most bars. All the transect locations ended in mature cottonwood stands.

\section{Figure 17. The distribution of tree species relative to September flows on the Wasa study reach.}

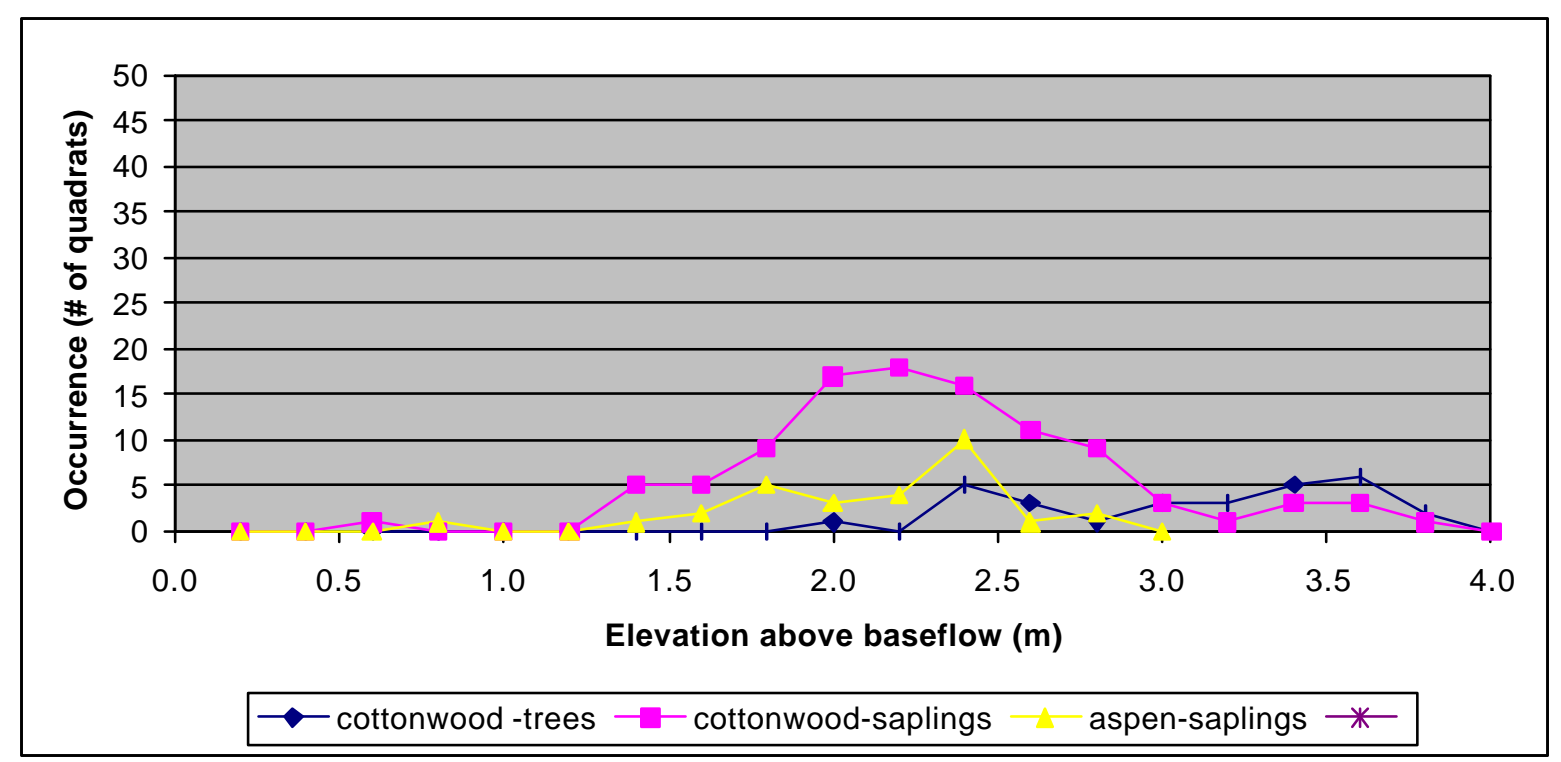

\subsubsection{Stand Health}

Cottonwood Stand Age: Cottonwood trees were cored on each transect. We found trees between 100 and 200 years of age on two transects, the remainder of the trees cored were between 31 and 85 years of age (mean age $=57.2, n=35$ ). We observed good vigour in all stands.

Cottonwood Recruitment: Although we saw few cottonwood seedlings of the year, recruitment from seedlings had occurred in recent years and resulted in the presence of cottonwood saplings, generally mixed with willow, in bands along the point bars. Older trees (5-25 years) were uncommon. It would appear that the fine silty soils found on point bars in this study reach favour willow establishment over cottonwood. These soils have high moisture retention and thus are generally too wet for cottonwood establishment. We did observe some saplings growing at the drip line of mature cottonwood stands that were likely root suckers. 
Exotic Plants: Quack grass and red top, (both exotics) were common on many transects. We saw little evidence of reed canary-grass, a native invasive grass species, on the river banks in this reach. Several exotic herbs were encountered but none of these dominated riverbank sites. We saw no evidence of plains cottonwood in this reach.

Noxious Weeds: Individual plants of hound's tongue and spotted knapweed, two noxious weeds of concern in the surrounding area, were recorded. (Similar work on the Yakima River has found very high levels of noxious weeds in riparian vegetation there).

\subsection{WARDNER TO LIBBY DAM (INUDATED REACHES)}

Approximately $136 \mathrm{~km}(84.5 \mathrm{mi})$ of the mainstem Kootenai was flooded by the Libby Reservoir. We looked at pre-dam air photos of this reach. Extensive stands of cottonwood occurred on unconstrained alluvial floodplain areas in the Wardner area, below Sand Creek and from the outflow of the Elk River to Rexford, Montana. An assessment of the loss of riparian habitat has been completed for the US side of the impoundment area (Yde and Olsen 1984). They found a total of 873 acres of cottonwood riparian and 2, 511 acres of mixed riparian (deciduous and conifer) stands were flooded. These stands represented $11.7 \%$ of the area flooded on the US side. No similar work has been completed on the Canadian side.

\subsection{LIBBY DAM TO MOYIE REACH}

This portion of the river is in a narrow valley with a narrow floodplain. Downstream of Troy to the Moyie River confluence the river is in a steep walled canyon. Some development has occurred historically around the communities of Libby and Troy, but there are few farms on the floodplain and no extensive agricultural development. Cottonwood stands are rare in this reach and generally $<10 \mathrm{~m}$ wide. Larger stands probably occurred pre-settlement on the alluvial outflow areas of Libby and Callahan Creeks. These sites are now occupied by settlements (Libby and Troy). One large stand of cottonwood (10 ha) is located adjacent to Troy on the alluvial fan of Callagan Creek. Most of the stand is mature but there are some small pole stand stands (.5 ha) on the outflow of the creek into the Kootenai River. There are also a few stands remaining on tributary streams such as the Fisher River (M.L. Polzin, pers. comm.) and Lake Creek. There are very few cottonwood stands on the Yahk River and lower Moyie River although more extensive stands are found in the Upper Moyie in Canada (see Jamieson et al. 2001).

No analysis was carried out in this reach. Previous work was completed in this reach in 1996 and 1997 (Polzin and Rood 2000). They found no seedling establishment on a study site below the Libby Dam in years in which significant recruitment occurred along the Upper Kootenai upstream of the reservoir and on the Fisher River (536 and 142 seedlings per $\mathrm{m} 2)$. 


\subsubsection{PRE AND POST DAM HYDROGRAPHS.}

The hydrograph of the Kootenai River in this reach has been severely altered by the operation of the Libby dam since 1975. The high early spring flows found prior to 1975 (Figure 18) were replaced by controlled flows that fluctuate daily and weekly, depending on power demands, but rarely exceed $1200 \mathrm{cms}$ in the 1975 to 1990 era (Figure 19). Higher spring flows have occurred in the 1991-2000 period in an attempt to stimulate white sturgeon recruitment (Figure 20). These flows are described in detail later.

Figure 18. Pre-dam hydrograph at Libby, 1955-1970.

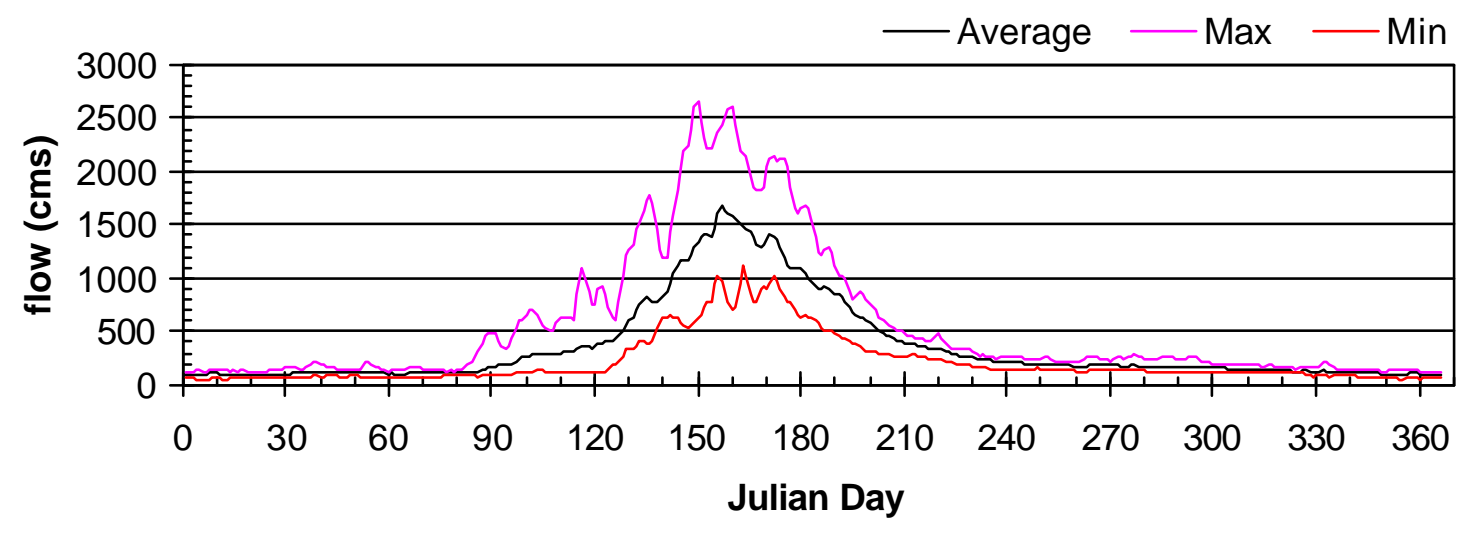

Figure 19. Post-dam hydrograph at Libby, 1975-1990.

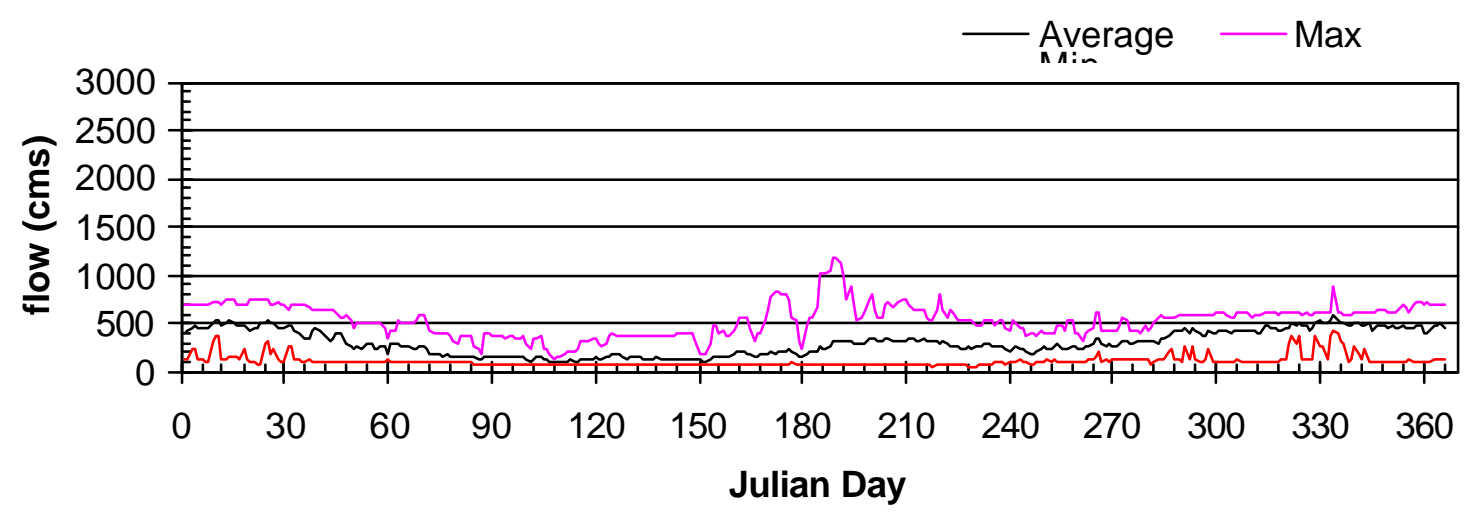


Figure 20. Post-dam hydrograph at Libby, 1991-1998.






\subsection{MOYIE CONFLUENCE TO BONNER'S FERRY REACH}

This portion of the river is a cobble and braided system with active channel migration. Much of the reach is diked, but the dikes are set back from the river for in most areas. The railway grade on the south side is located at the toe of the slope in some areas, but limits former river flooding into extensive floodplain areas to the south. The dike on the north side of the river is adjacent to the river at Bonner's Ferry but moves away from the river further upstream. As a result, the river is largely unconfined.

\subsubsection{EARLY HISTORY}

The railway grade and the dike on the north side of the river were established early in the century. These dikes however were not effective in controlling flooding in high flow years such as 1948 prior to the completion of the Libby dam.

\subsubsection{PRE AND POST DAM HYDROGRAPHS.}

The hydrograph at Bonner's Ferry was similar to that at the Libby dam, with the addition of minor inflows from tributaries downstream of the dam. The most important of these are the Fisher, Yahk and Moyie Rivers. These tributaries increase flows in the Kootenai River by about $7 \%$ at low flows and $22 \%$ in high flow periods in the spring.

Prior to construction of the Libby dam, flows in this area were very dynamic, with spring flows that regularly peaked $10 \mathrm{~m}$ (30 feet) above average winter flows (Figure 21). Post dam flows for the 1975 to 1990 era (Figure 22) were highly regulated. Flows in this period were highly modified with severely reduced spring flows, summer flows that were low compared to historic conditions and higher and fluctuating winter flows. These highly-modified flows have a major impact on riparian vegetation along this portion of the river.

Starting in 1991, spring flows were manipulated in an attempt to produce flows below Bonner's Ferry that would stimulate white sturgeon spawning (USFWS 2000). Different types of releases were tested in each year. These releases provided this project with the opportunity to examine the effects of these various releases on cottonwood recruitment. The average hydrograph (1991-2000) for this period is provided in Figure 23. 
Figure 21. Daily stage at Bonner's Ferry, 1963-1971.*

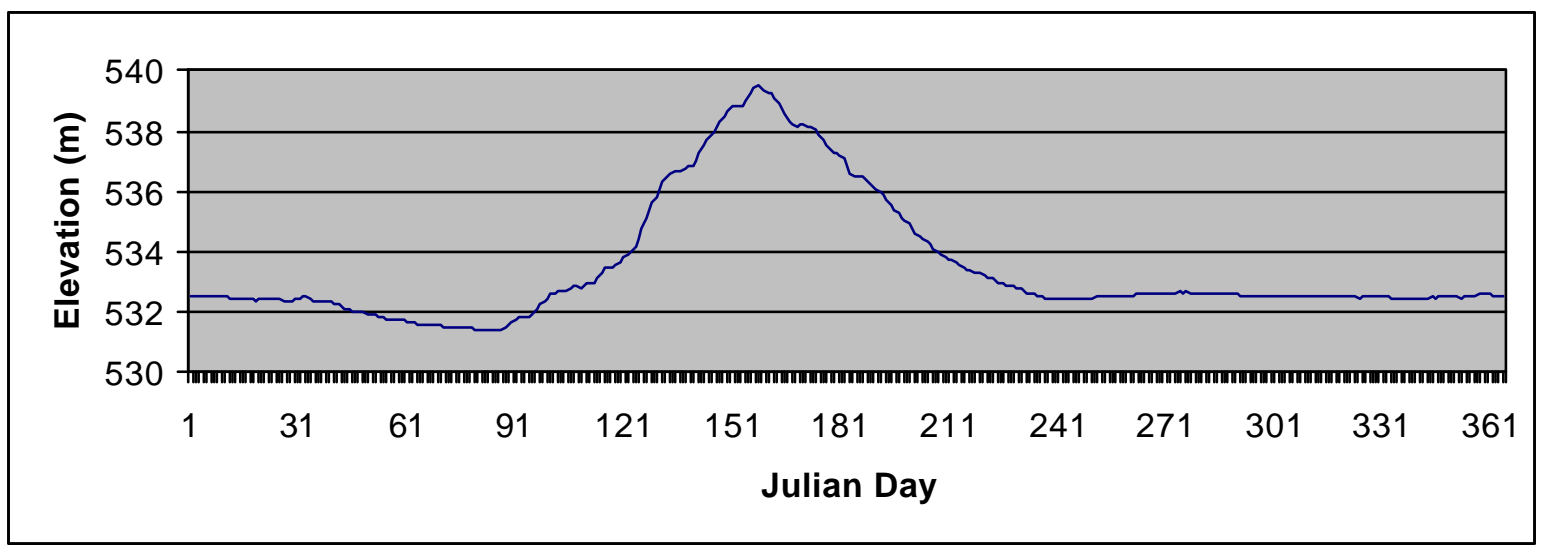

\section{Figure 22. Daily stage at Bonner's Ferry, 1975-1990.*}

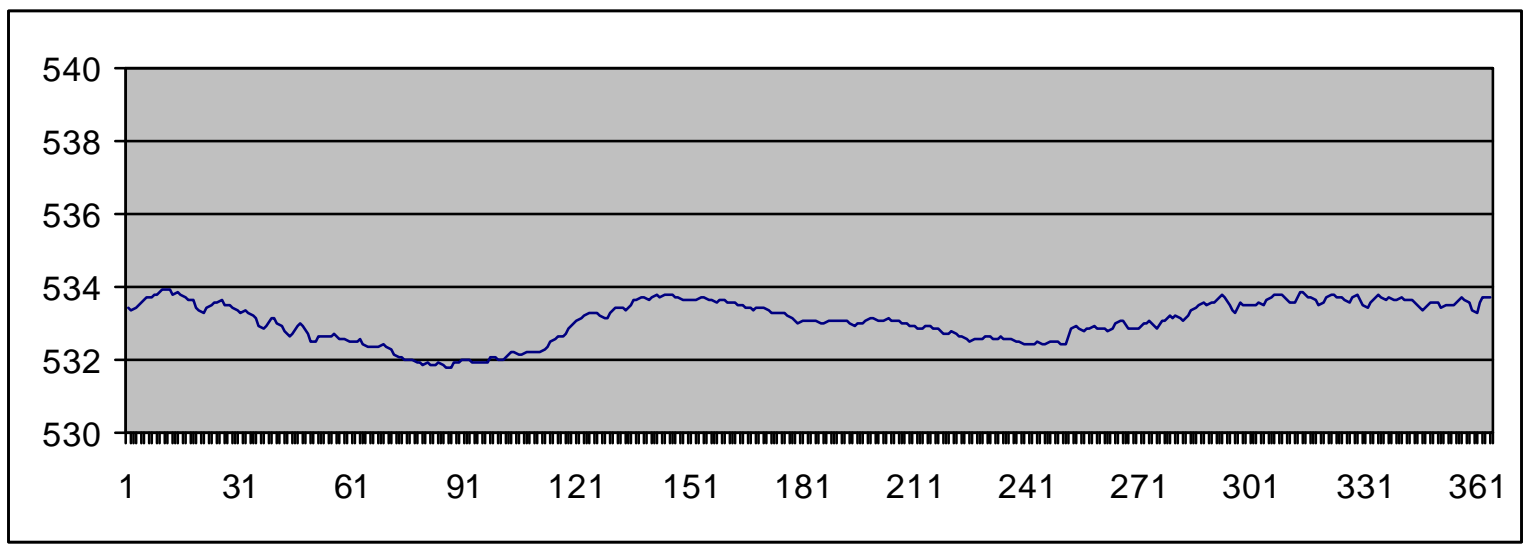

Figure 23. Daily stage at Bonner's Ferry, 1991-2000.*



* Some years with data gaps were not included. The years 1972 to 1974 were not included since they had irregular hydrographs resulting from the filling of reservoir. 


\subsubsection{MOYIE CONFLUENCE TO BONNER'S FERRY STUDY REACH}

\subsubsection{Riparian Habitat Change in recent decades}

Table 2 describes the changes in habitat types over time in this study reach, based on air photo interpretation. Habitat mapping for 1931, 1968 and 1991 is provided in Figures 24 to 26 .

Table 2. The area of different habitat and land use types in the Moyie study reach in 1934, 1968 and 1991.

\begin{tabular}{|lrrr|}
\hline Habitat Type (ha) & $\mathbf{1 9 3 4}$ & $\mathbf{1 9 6 8}$ & $\mathbf{1 9 9 1}$ \\
\hline Cottonwood-Mature & 156.07 & 299.64 & 170.29 \\
\hline Cottonwood-Immature & 31.88 & 13.32 & 13.92 \\
\hline Aspen & 0 & 0 & 0 \\
\hline Conifer & 3.67 & 4.54 & 5.59 \\
\hline Cleared & 259.47 & 369.84 & 404.75 \\
\hline Brush & 27.68 & 15.05 & 28.57 \\
\hline Meadow & 403.35 & 207.03 & 313.93 \\
\hline Range & 0 & 0 & 0 \\
\hline Water and bar & 359.01 & 338.15 & 210.17 \\
\hline Wetland & 0 & 0 & 0 \\
\hline Urban & 12.72 & 11.54 & 14.11 \\
\hline & & & $\mathbf{1 2 5 9 . 3 7}$ \\
\hline TOTAL & $\mathbf{1 2 5 3 . 8 6}$ & $\mathbf{1 2 5 9 . 1 1}$ & \\
\hline
\end{tabular}









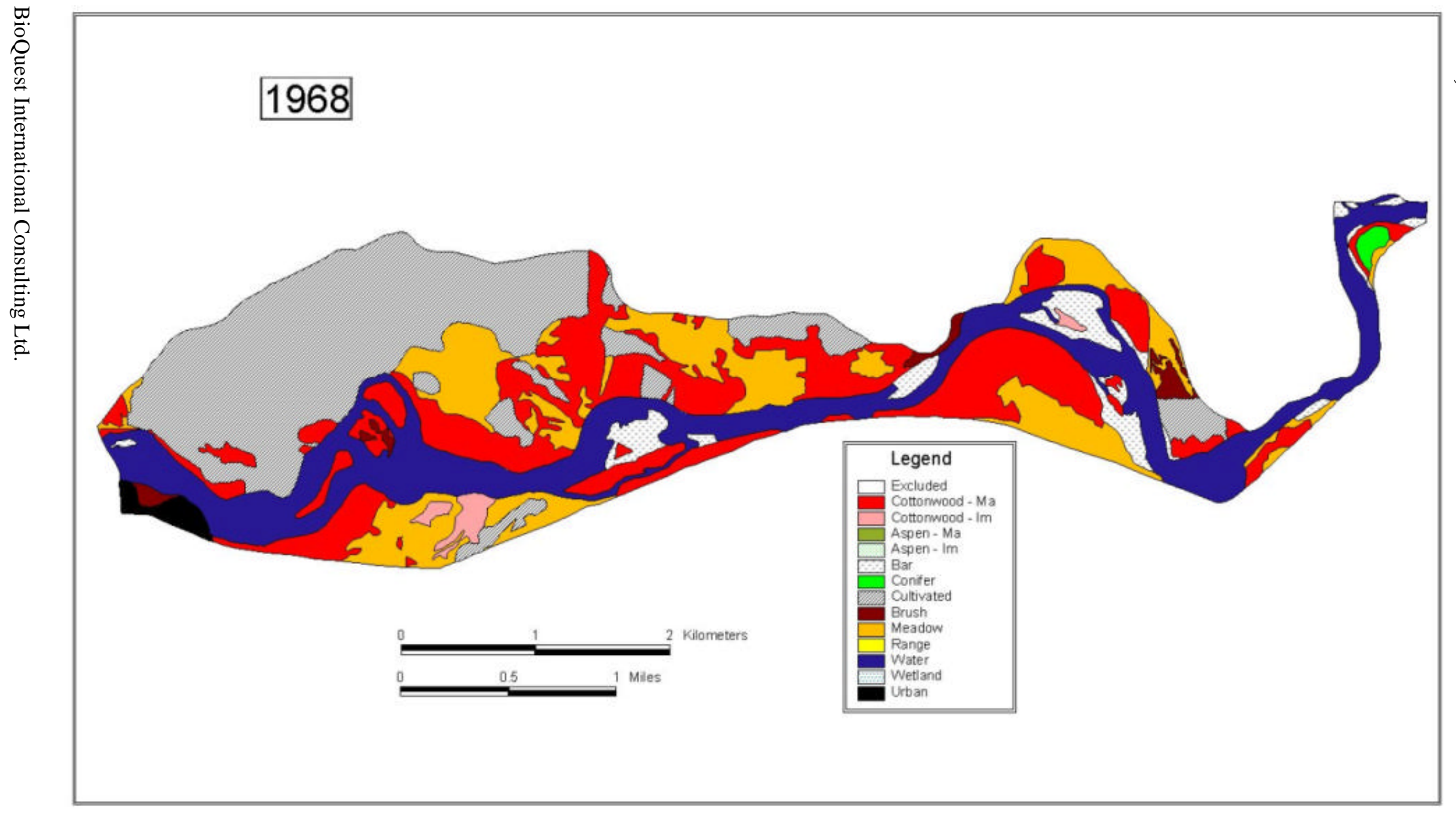

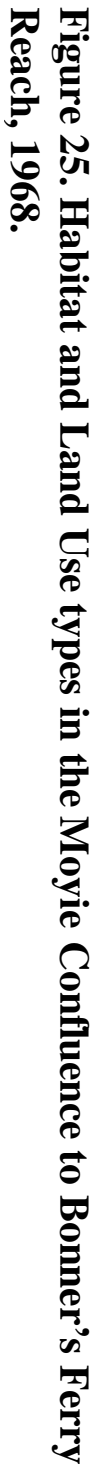




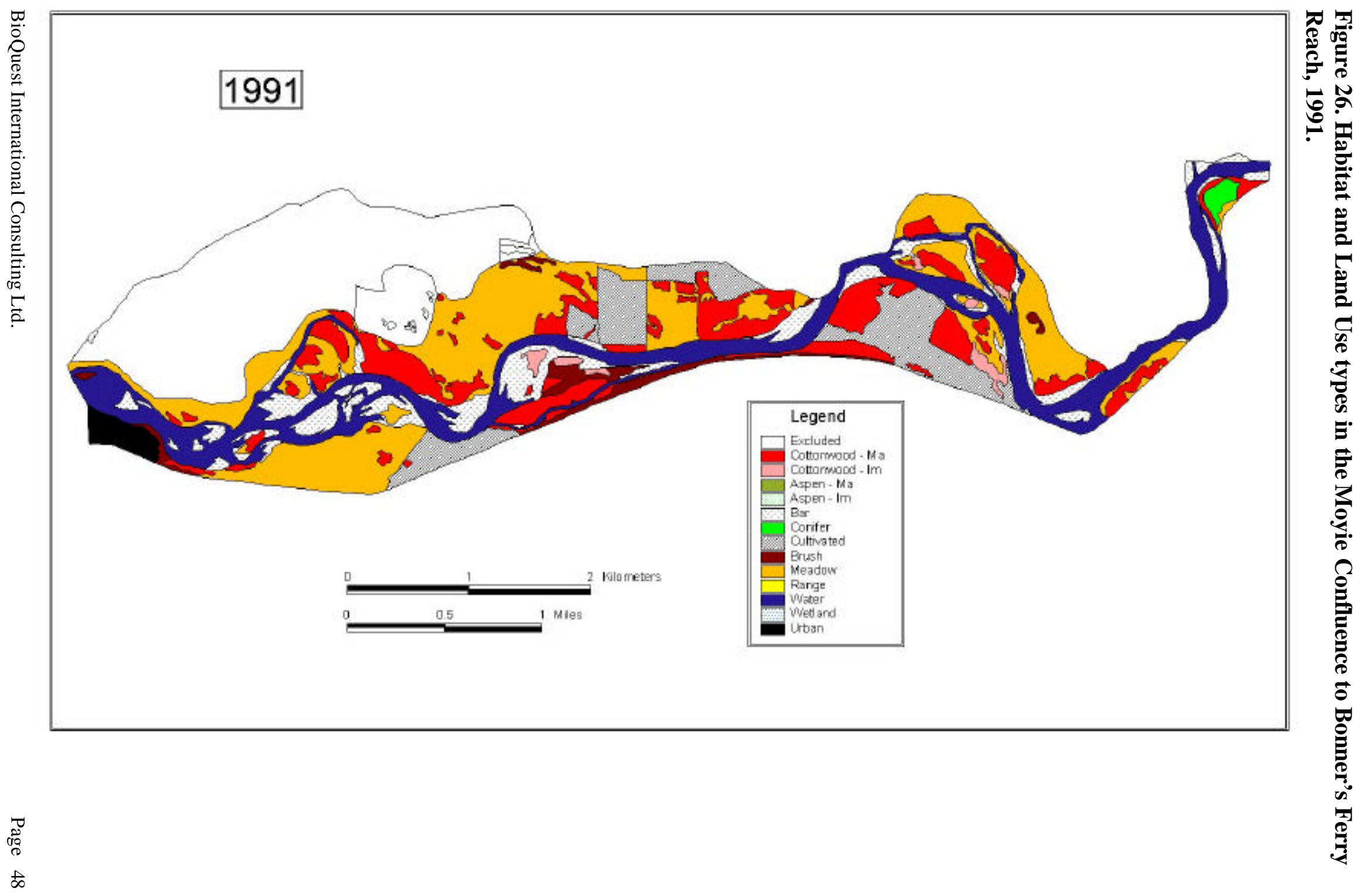


Based on this analysis we found that:

- Mature cottonwood stands in this reach increased from 1931 to 1968 and then declined in 1991. Three general age classes of stands were observed. There are several mature stands dating from prior to flow regulation. We also found some young sapling stands $(2.5 \mathrm{~cm}$ dia. $)$ and some stands of pole stage and larger diameter trees to $20 \mathrm{~cm}$ ( 8 in) dbh on point bars. Immature stands made up $17.0 \%$ of all cottonwood stands in 1934. This declined to $4.2 \%$ in 1968 and increased slightly to $7.6 \%$ by 1991 .

- No aspen occurs in this reach and conifer stands are minimal.

- Much of the floodplain was cleared and cultivated prior to 1934. Extensive clearing also occurred between 1934 and 1968, primarily in the area north of the river near Bonner's Ferry. This area was diked prior to 1934 but these dikes were probably ineffective in controlling flood events in many years. Much of the area was in meadow in 1934 and 1968 but has since been converted mostly to cultivated land with the advent of flood control. This area behind the dike is now effectively outside the active floodplain.

- The area occupied by water, gravel and side-channel bars seems to have declined significantly from 1934 (359.01 ha) to 210.17 ha in 1991.

- We documented the area of gravel and side-channel bars for this reach since scroll and point bars are a very important component of this reach, however, this data is not reliable since the extent of the bars mapped was dependent on the river level on the day the air photos were taken.

- The area occupied by settlement in this study reach in relatively minor. A portion of the town of Bonners was included in the study area. There is no habitation on the floodplain as presently defined by dikes and the railway grade.

We noted significant changes in the period between 1991 and 2001 when we did field work in this reach. Gravel mining is occurring at one site and one area of mature cottonwood has been cleared since 1991. One area of meadow has recently been converted to an ornamental tree nursery and we observed two sites with severe grazing impacts.

\subsubsection{Present distribution of cottonwood stands in the study reach.}

Extensive cottonwood stands occur in this study reach. (Figure 27). Mature stands occupy $13.5 \%$ of the study reach area, immature stands occupy $1.1 \%$. 


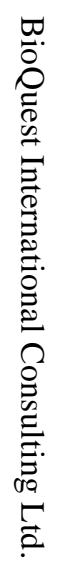

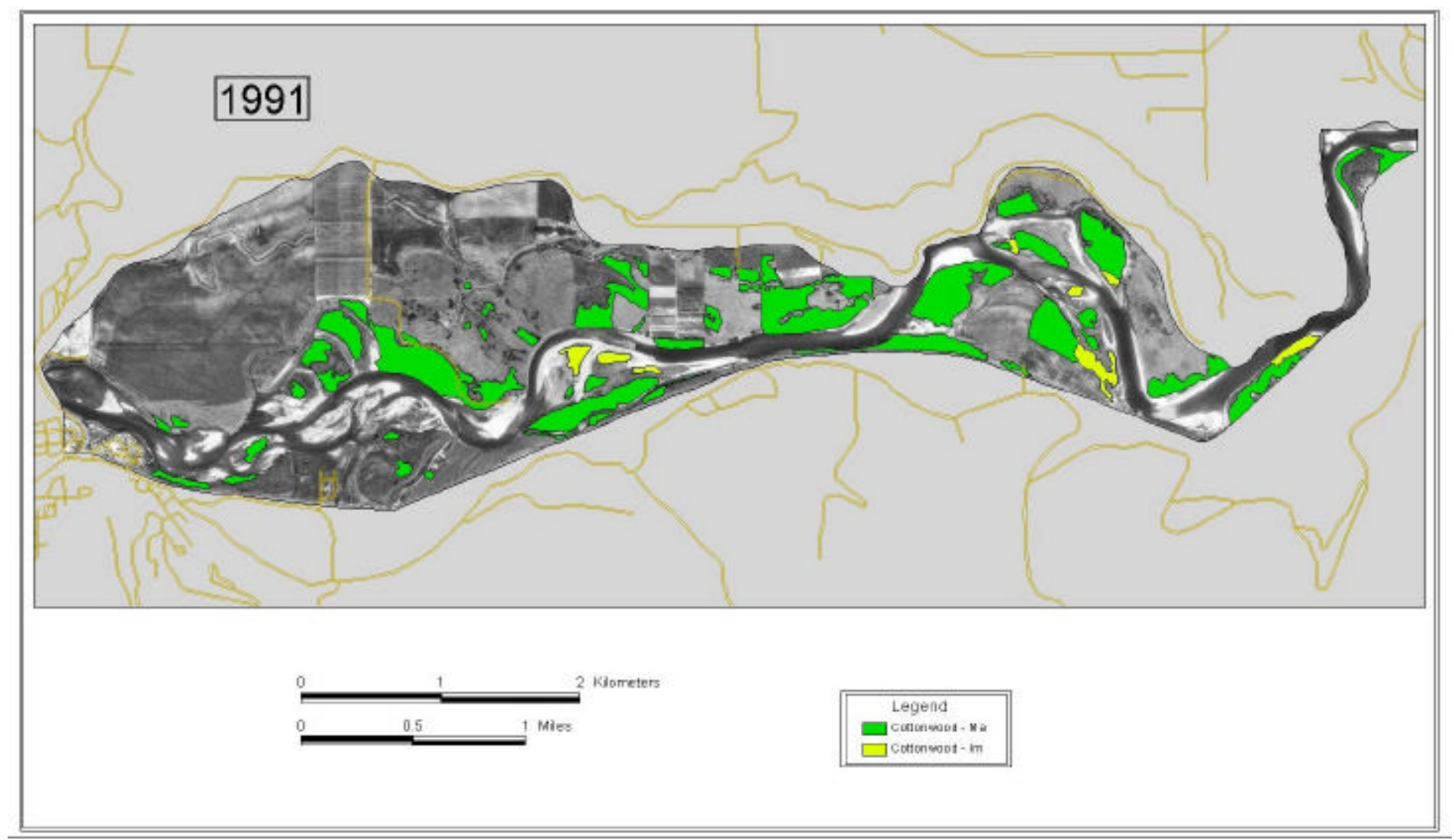

है ซิ

วิ

ㄱ. ㄱ.

告

$\leq$

กิ

ㅇํㄹ

홍

를.

อ.

o

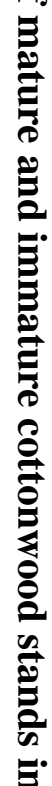




\subsubsection{River bank profiles.}

Elevation profiles for the five transects $(0-50 \mathrm{~m})$ in this reach are provided below. In most cases there was a relatively gentle gradient along these transects.

Figure 28. Elevation profiles for the Moyie confluence to Bonner's Ferry Reach.

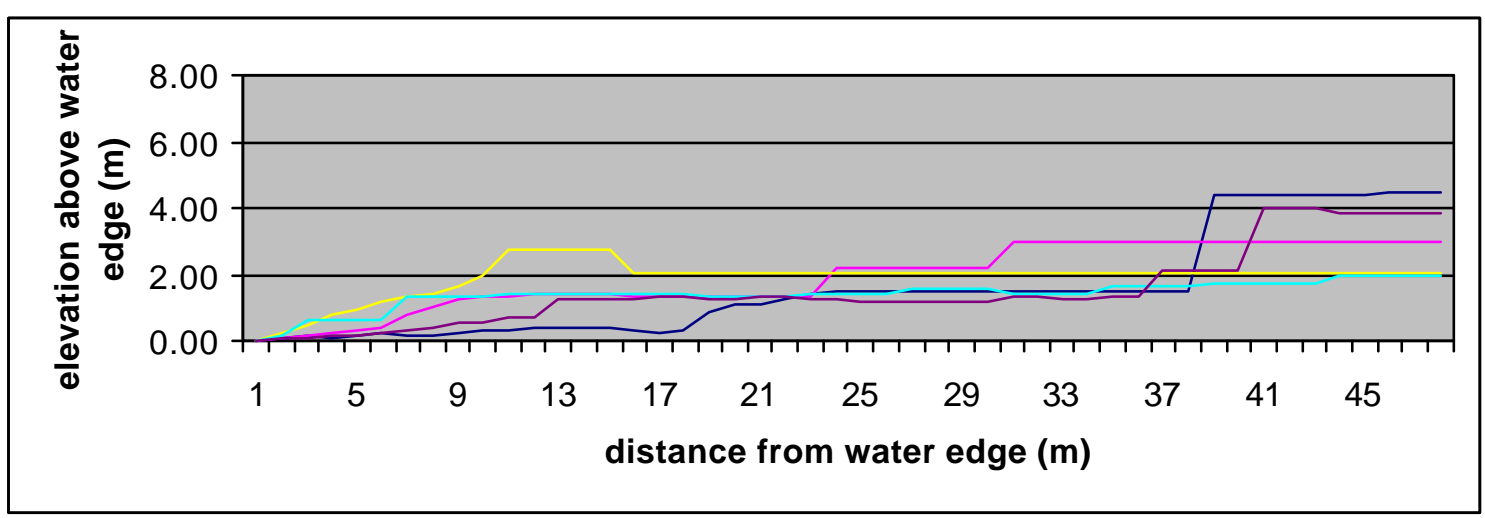

\subsubsection{River bank plant communities.}

In this reach, the river bank consisted primarily of gravel and cobble, although the substrate was dominated by fine materials on two downstream transect sites. For these two transects, which were most representative of this reach, we found a grass community of 2 annual and 13 perennial species (Figure 29), dominated by quack grass, red top, reed canary-grass and Canada bluegrass. The forb community consisted of 8 annual and 27 perennial species (Figure 30).

Figure 29. The distribution of annual and perennial grasses relative to base September flows on the Moyie confluence to Bonner's Ferry study reach. 




Figure 30. The distribution of forbs relative to base September flows on the Moyie confluence to Bonner's Ferry study reach.

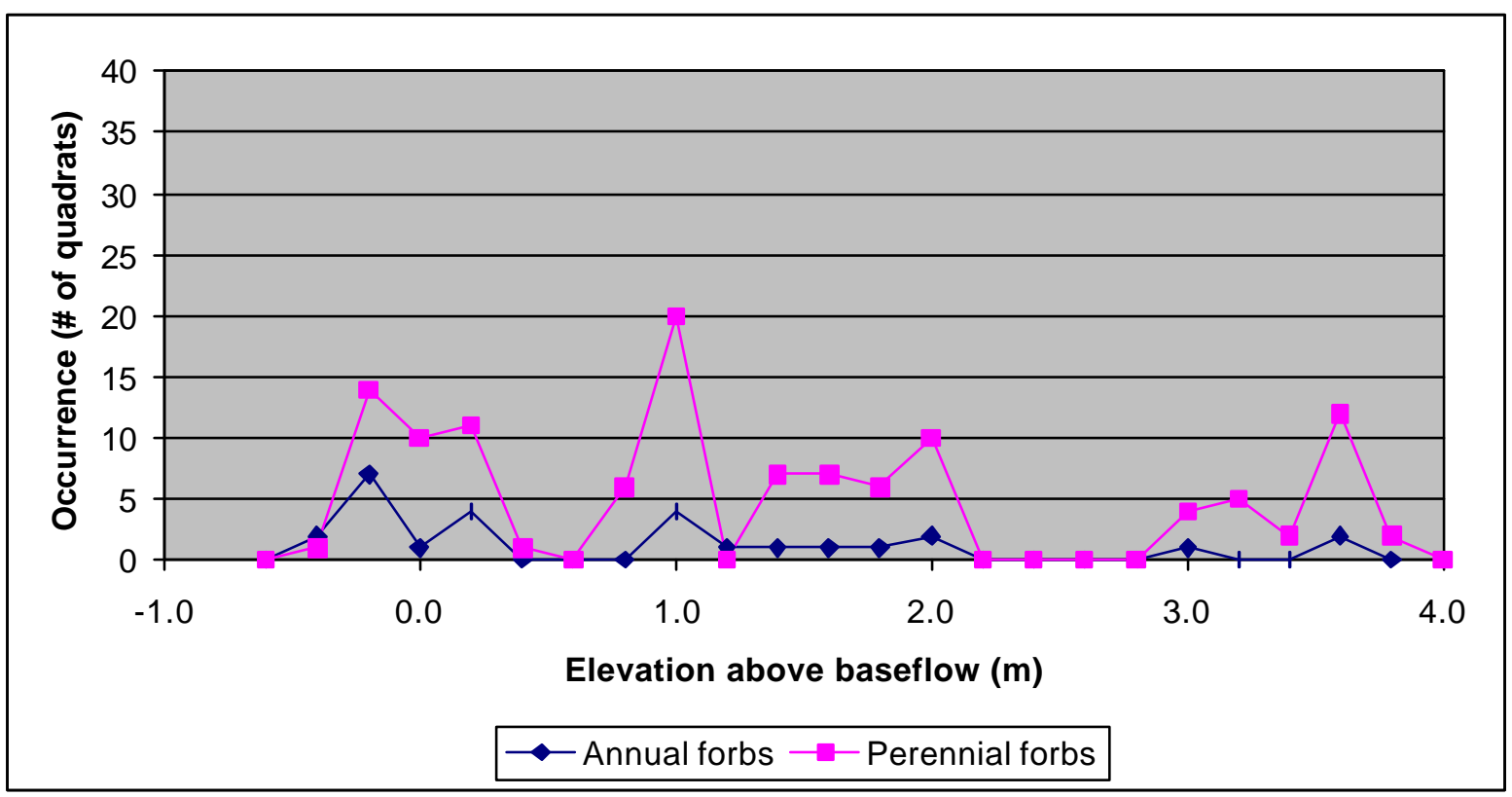


Woody shrubs were uncommon, with Begg's and Coyote Willow most common at 0.0 to $2.0 \mathrm{~m}$ above base flows.

Figure 31. The distribution of woody shrubs relative to base September flows on the Moyie confluence to Bonner's Ferry study reach.

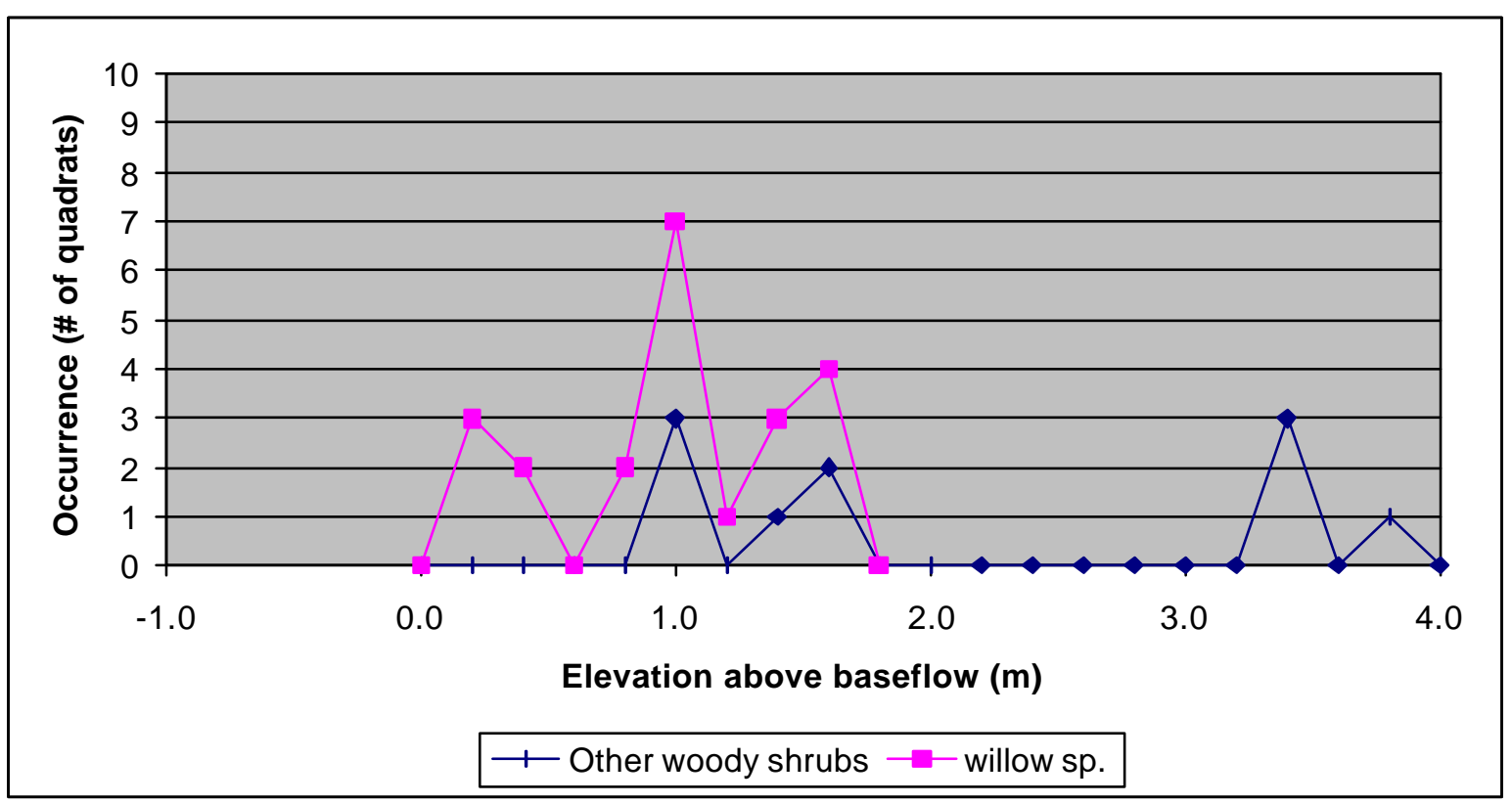




\subsubsection{The distribution of tree species by elevation.}

We found aspen seedlings at low elevations on one transect, but no cottonwood seedlings. Extensive cottonwood (all black cottonwood) saplings occurred at .5-2.0 m in elevation above base flows. These transects traversed fairly large flats supporting stands of sapling cottonwood and willow species (See photos in Appendix I).

Figure 32. The distribution of tree species relative to base September flows on the Moyie study reach.



\subsubsection{Stand Health}

Cottonwood Stand Age: 13 tree cores were collected. Ages ranged from 27 to 96 years $($ mean $=54.2)$.

Cottonwood Recruitment: We found five sites with extensive cottonwood recruitment on bars in this reach. On two sites, saplings occurred over an area of 2-3 ha (See Appendix I.). Most sites were of recent origin (within 5 years) but there were a few sites with trees 10-30 years of age. We did not find any seedlings of the year in this reach.

Exotic Plants: Exotic grasses (6 of 15 grass sp.) and forbs ( 22 of 35 forbs) were common in this reach. No plains cottonwoods were identified.

Noxious Weeds: Spotted knapweed was observed on these transects (11 occurrences). 


\subsection{BONNER'S FERRY TO KOOTENAY LAKE REACH}

In this reach, the floodplain and river channel have been highly modified by human activity.

\subsubsection{EARLY HISTORY}

The Ktunaxa/Kootenai peoples used this area extensively prior to white contact. The first recorded white contact in this area occurs in May of 1808 when David Thompson camped in the Bonner's Ferry area in a "fine meadow" after leaving the "steep and rocky banks" of the upstream reach (Nisbet 1994). A trading post at Deep Creek near Bonner's Ferry was established in 1811 (Boundary County Historical Society 1987) and there was a substantial white presence by 1850 . A railway was built up the valley in 1892 as far as Kootenay Lake. Although there were early discussions of river diversions at Canal Flats (Scott and Hanic1974) to allow agricultural expansion in the Creston area, there were no serious attempts at diking the river during this era. There was some unsuccessful diking attempts in 1892, 1898, 1903 and 1904 on the Canadian side but these dikes failed, generally within one or two years (Dennington 1996).

During this era, natural processes along the river continued essentially unaltered by human activity. Paul Flinn, who was born in1913 in the Bonner's Ferry area, noted that, prior to 1921, that the Kootenai valley floor was "a labyrinth of cottonwood trees, lakes, mud, shallow waters, mosquitos and numerous treed islands" (Boundary County Historical Society 1987). Farwell 1883 described the Creston area as: "These flats, including the island, are open prairies, with fringes of cottonwood and brush, varying in width from a few yards to 3 or 4 chains." He also noted that "the main river banks are considerably higher than the land toward the foothills' and "...At the boundary, on the $10^{\text {th }}$ October, the banks are 15 feet high...", indicating that significant natural levees occurred along the main river channel. Dennington 1996 quotes Constable, who indicated "that the river banks averaged 22 feet above low water and 10-15 feet above the flood basins on either side".

These observations and the early mapping and photos provided in Appendix II indicate that the Bonner's Ferry to Creston reach was a complex mix of channels, wetlands and cottonwood stands prior to settlement. This area was probably one of the largest and richest riparian forest and wetland complexes in the Pacific north-west, covering some 55,000 acres. If form and function, the area was probably very similar to what occurs today in the Columbia Wetlands on the Upper Columbia River, with large seasonal wetland areas, sedge meadows, willow communities and cottonwood stands along the natural levees of the river and on the alluvial fans of tributary streams (Jamieson and Hennan 1998). 
The first serious attempt at diking areas for agriculture was initiated in 1921 when 6000 acres were diked at Bonners Ferry. Fifteen diking districts were formed over the next 12 years so that by 1940, most of the reach was diked (Boundary County Historical Society 1987). Dike construction was initiated in the Creston area in 1934 (Dennington 1996). At that time the Cora Linn dam was built at the outlet of Kootenay Lake. This dam allowed some control of the level of Kootenay Lake and the degree to which the Creston flats flooded. In 1938, the Grohmann narrows, a constriction below Kootenay Lake that controlled the level of the lake in spring, was widened and potential flood levels were reduced by several feet (Dennington 1996). Prior to that time, elevated levels in Kootenay Lake were a major contributor to flooding conditions in this reach due to the low gradient of this reach. The dikes constructed throughout the reach were reasonably successful until the major flood in 1948. Regular repair of the dikes was required following flood events into the 1970's when flood control was provided by the Libby dam. The Creston Valley Wildlife Management Area was established in 1948 and the Kootenai National Wildlife Refuge in the 1964. In both areas managed wetlands have been developed behind the dike.

\subsubsection{PRE AND POST DAM HYDROGRAPHS}

The hydrograph in the Upper portion of this reach is the same as that for Bonner's Ferry (provided in the previous section). There are no major inflows in the US portion of this reach and flows at Porthill are essentially unchanged from those for the Bonner's Ferry. The Goat River, on the Canadian side, provides average annual inflows $(.73 \mathrm{cms}, 25.9$ cfs) that would affect the hydrograph from Creston to Kootenay Lake only in a minor way. 


\subsubsection{DEEP CREEK TO SHORTIE'S ISLAND STUDY REACH}

This study reach is diked along the river edge and is representative of much of the Bonner's Ferry to Kootenay Lake reach. The only feature within the diked channel is Shortie's Island which supports a dense stand of cottonwood and is separated from the west bank by a small channel (10-20m wide) that is dry at low flows. Appendix I includes photos of the transect locations in this reach.

\subsubsection{Riparian Habitat Change in recent decades}

Table 3 and Figures 33 to 35 describe the habitat changes in the Deep Creek to Shortie's Island study reach from 1934 to 1991 based on air photo interpretation. This reach is representative of Bonner's Ferry to Kootenay Lake reach, with the exception of the area at the outflow into Kootenay Lake where more extensive cottonwood stands occur.

As in the previous study reach, much of natural riparian vegetation in this reach was cleared prior to 1934. The area of mature cottonwood stands declined by about $40 \%$ between 1934 and 1991 (57 years). It was not possible to identify immature cottonwood stands in the earlier photographs and there were no visible signs of recruitment in the 1991 photographs. In 1934 there were extensive areas of sedge meadows (954 ha). These lands were largely cultivated by 1968. In the 1968 to 1991 era, some of these lands were converted to wetlands and natural meadows on lands that were purchased to create the Kootenai National Wildlife Refuge. This resulted in an increase in wetland and meadow habitats and a decline in cultivated farmland area.

Table 3. Habitat types in the Shortie's Island study reach.

\begin{tabular}{|lrrr|}
\hline Habitat Type & $\mathbf{1 9 3 4}$ & $\mathbf{1 9 6 8}$ & $\mathbf{1 9 9 1}$ \\
\hline Cottonwood & 102.82 & 95.19 & 68.6 \\
\hline Aspen & 0 & 0 & 0 \\
\hline Conifer & 0 & 0 & 0 \\
\hline Cleared & 1322.58 & 2161.85 & 1750.93 \\
\hline Brush & 5.38 & 24.25 & 31.2 \\
\hline Meadow & 954.54 & 121.57 & 352.51 \\
\hline Range & 0 & 0 & 0 \\
\hline Water and bar & 187.4 & 176.19 & 185.18 \\
\hline Wetland & 13.54 & 7.21 & 197.91 \\
\hline Urban & 0 & 0 & 0 \\
\hline & & & 2586.33 \\
\hline TOTAL & 2586.26 & 2586.26 & \\
\hline
\end{tabular}


Figure 33. Habitat and Land Use types in the Shortie's Island study reach, 1934.

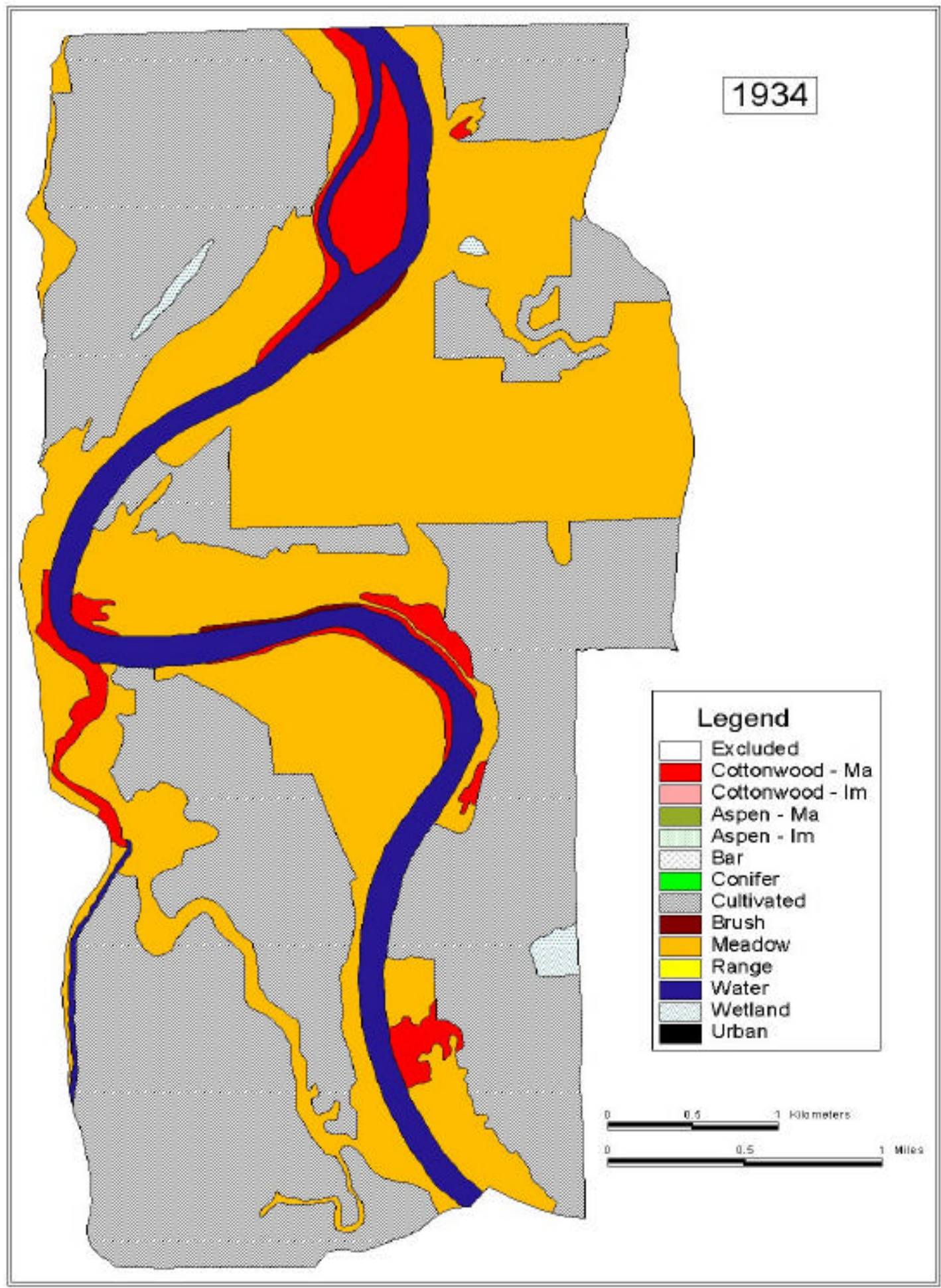

BioQuest International Consulting Ltd. 
Figure 34. Habitat and Land Use types in the Deep Creek to Shortie's Island study reach, 1968.

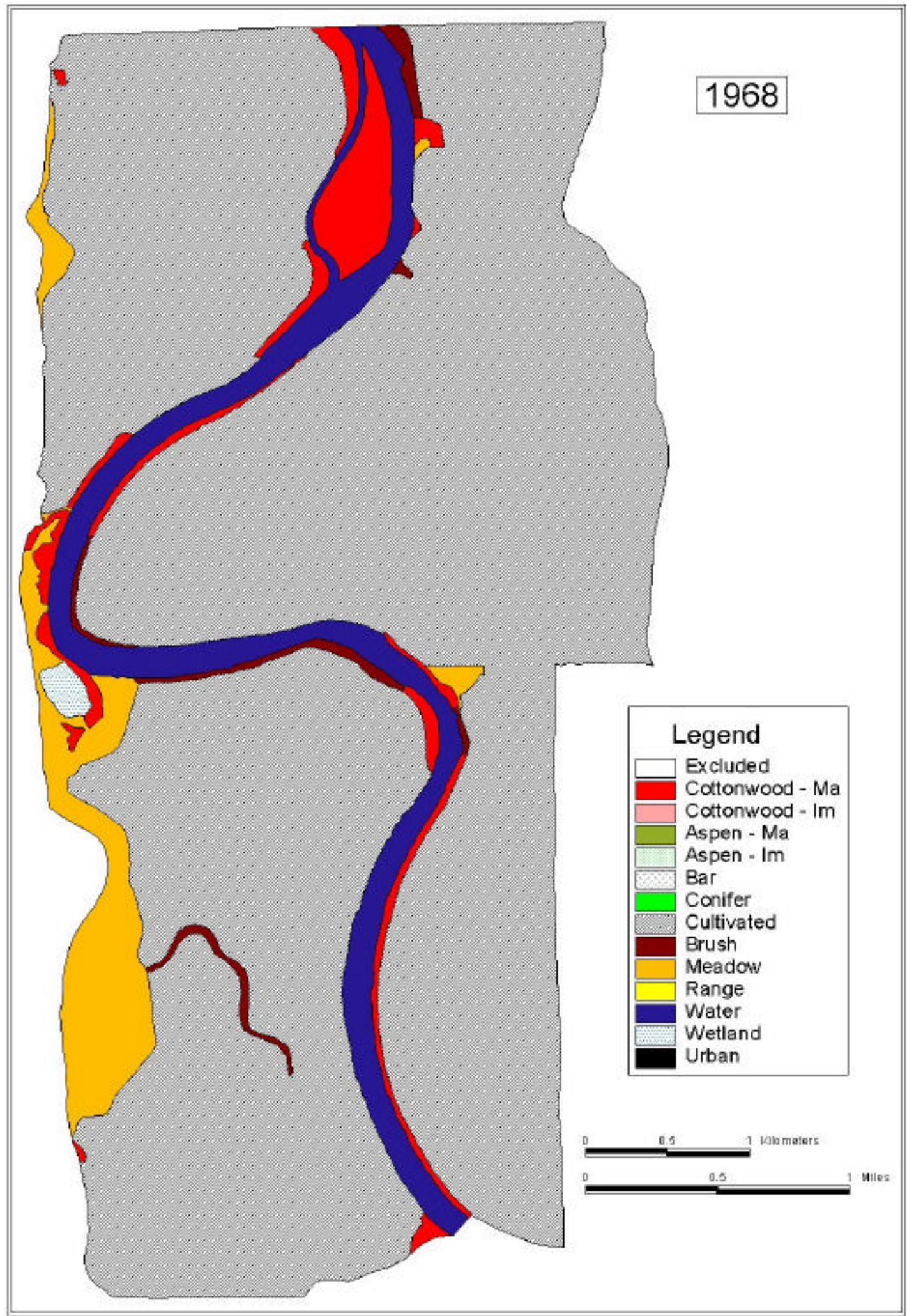

BioQuest International Consulting Ltd. 
Figure 35. Habitat and Land Use types in the Deep Creek to Shortie's Island study reach, 1991.

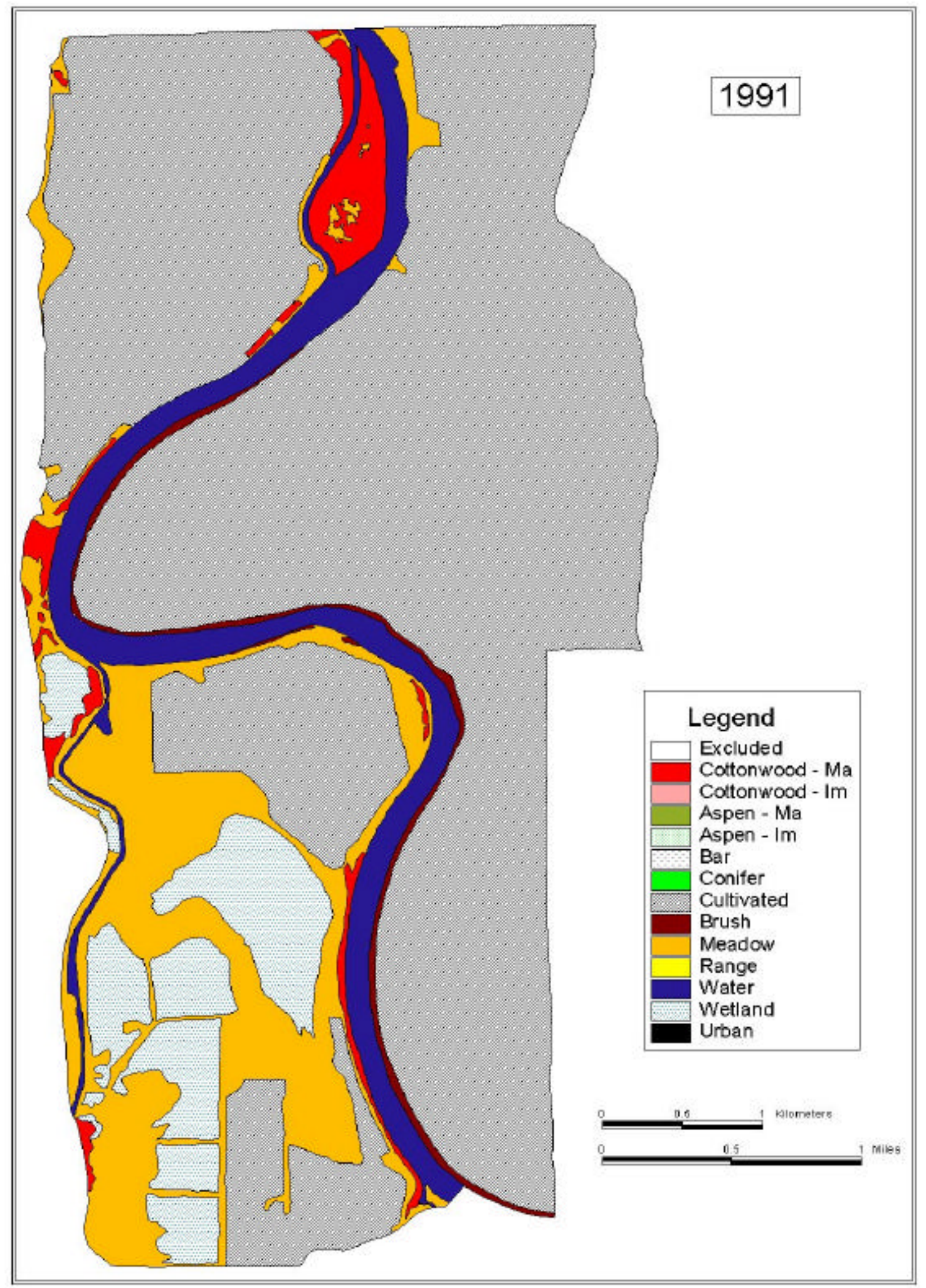




\subsubsection{Present distribution of cottonwood stands in the study reach.}

Cottonwood stands in this study reach occur in very narrow bands $(5-10 \mathrm{~m})$ along the river dikes and on a few sites west of the dike on the Kootenai National Wildlife Refuge.

Figure 36. The present distribution of cottonwood stands in the Shortie's Island study reach.

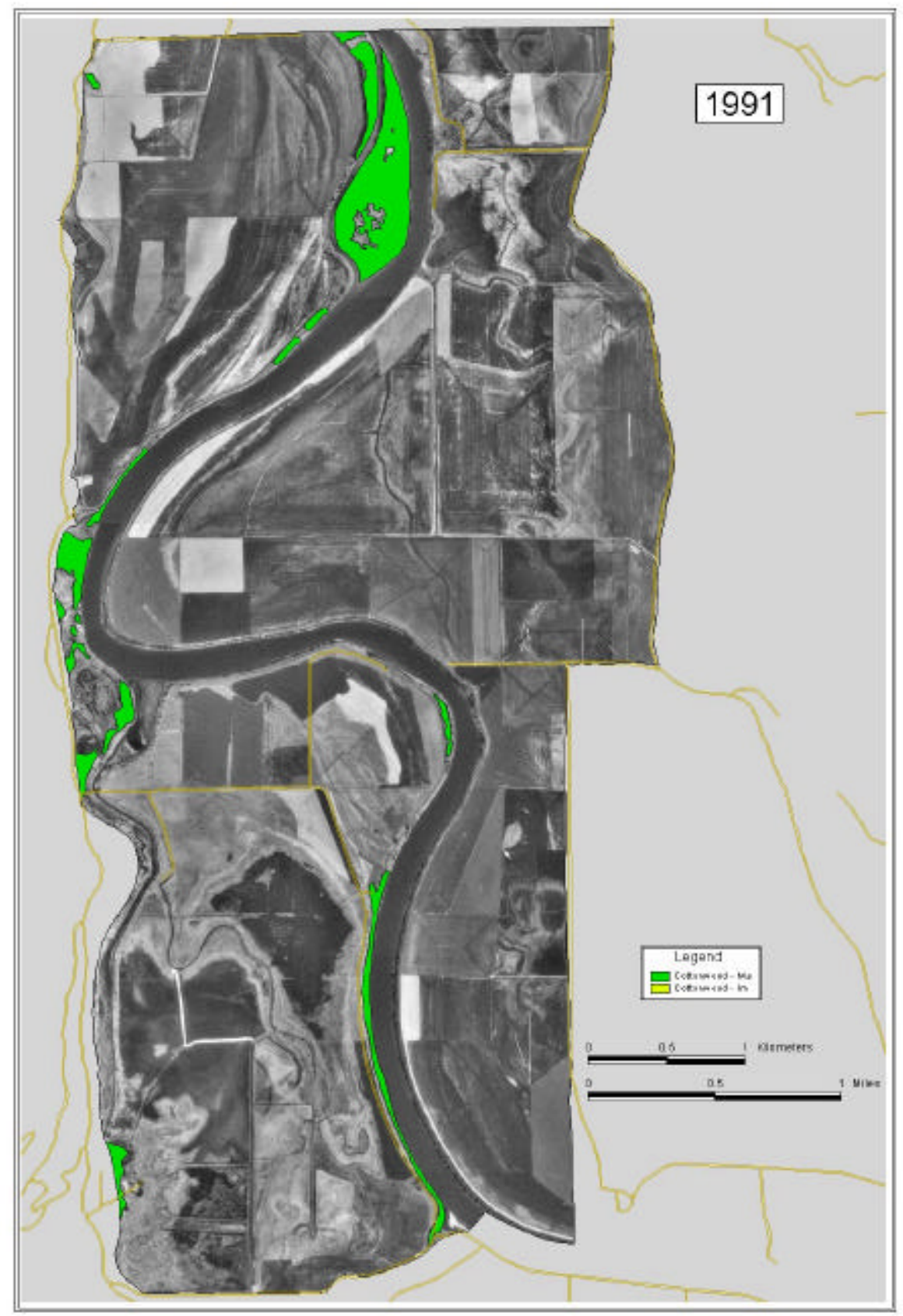




\subsubsection{River bank profiles.}

Five transects were established in this study reach. All were located on steep banks, either on Shortie's Island, or on the river dike adjacent to the Kootenai National Wildlife Refuge. In all cases, there was a steep gradient from the river to the top of the dike.

\section{Figure 37. Elevation profiles for transects in the Shortie's Island study reach.}



\subsubsection{River bank plant communities.}

The river's edge consisted of a mix of gravel and fine silts and sands. Most of the material used to build the dikes was composed of fine materials. We found a grass community made up of one annual (toad rush) and several perennial species (Figure 38). Grass communities were dominated by reed canary-grass, which is well adapted to stable flows on regulated rivers.

Four annual and 16 perennial forbs occur in this reach (Figure 39). Common tansy and common plantain were the most forbs. Only a few species of woody shrubs were recorded. 
Figure 38. The distribution of perennial grasses relative to base September flows in the Shortie's Island study reach.

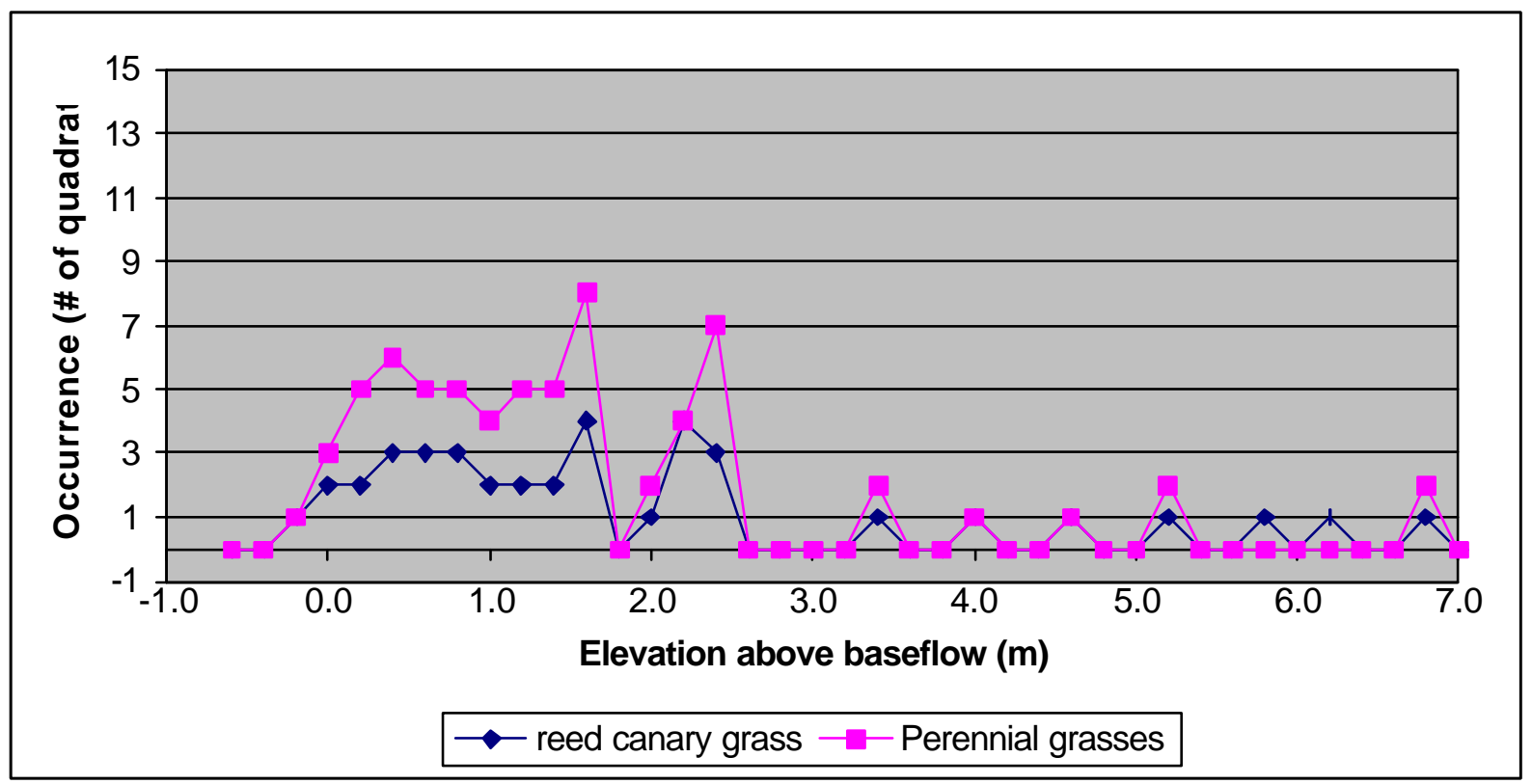

Figure 39. The distribution of forbs relative to base September flows in the Shortie's Island study reach.

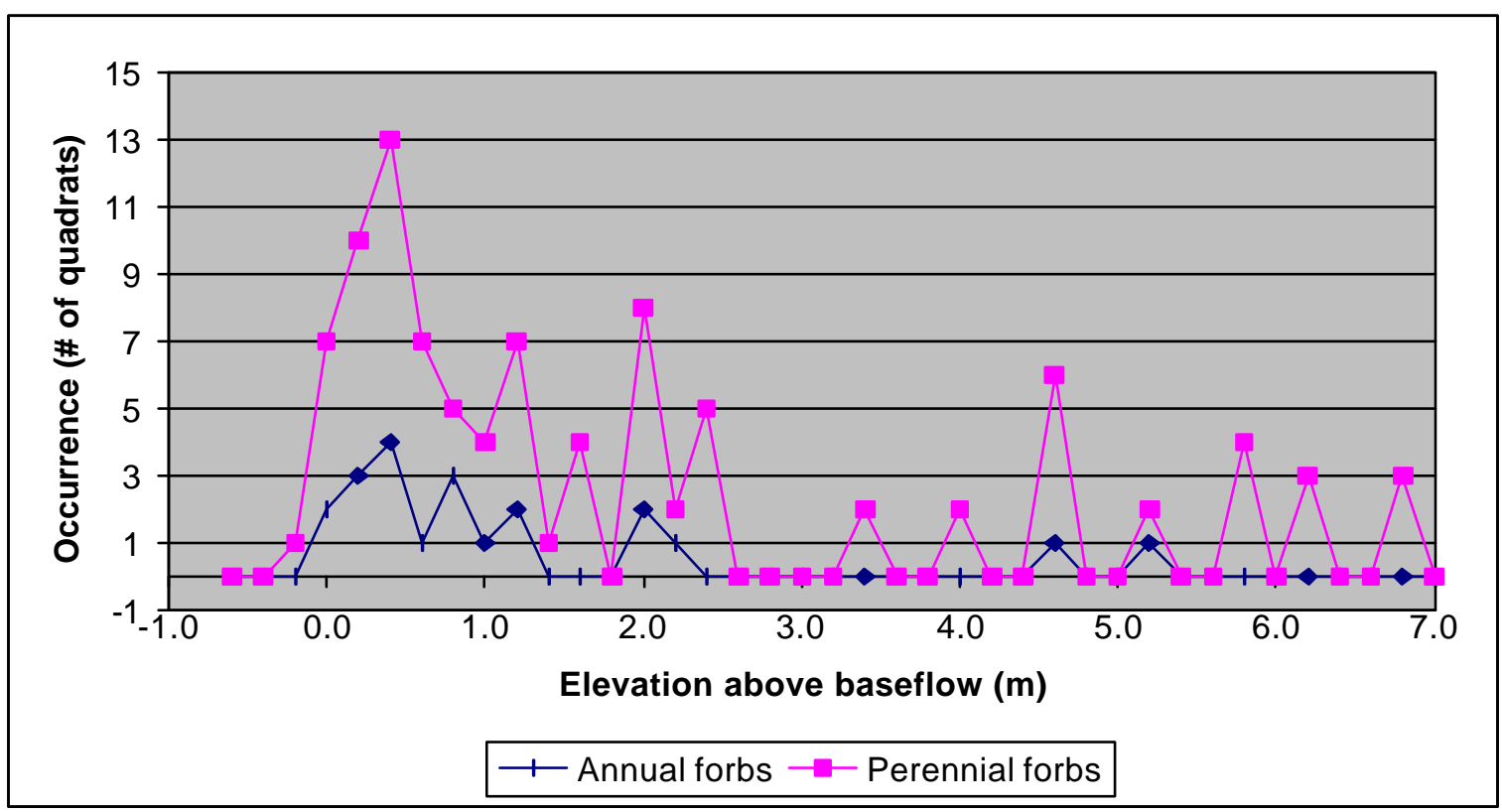




\subsubsection{The distribution of tree species by elevation.}

We found three Populus species in this study reach. Aspen seedlings were present along the river edge, but we recorded no cottonwood seedlings or saplings. The mature cottonwood stands along the dike consisted of a 50:50 mix of plains and black cottonwood.

Figure 41. The distribution of tree species relative to base September flows in the Shortie's Island study reach.

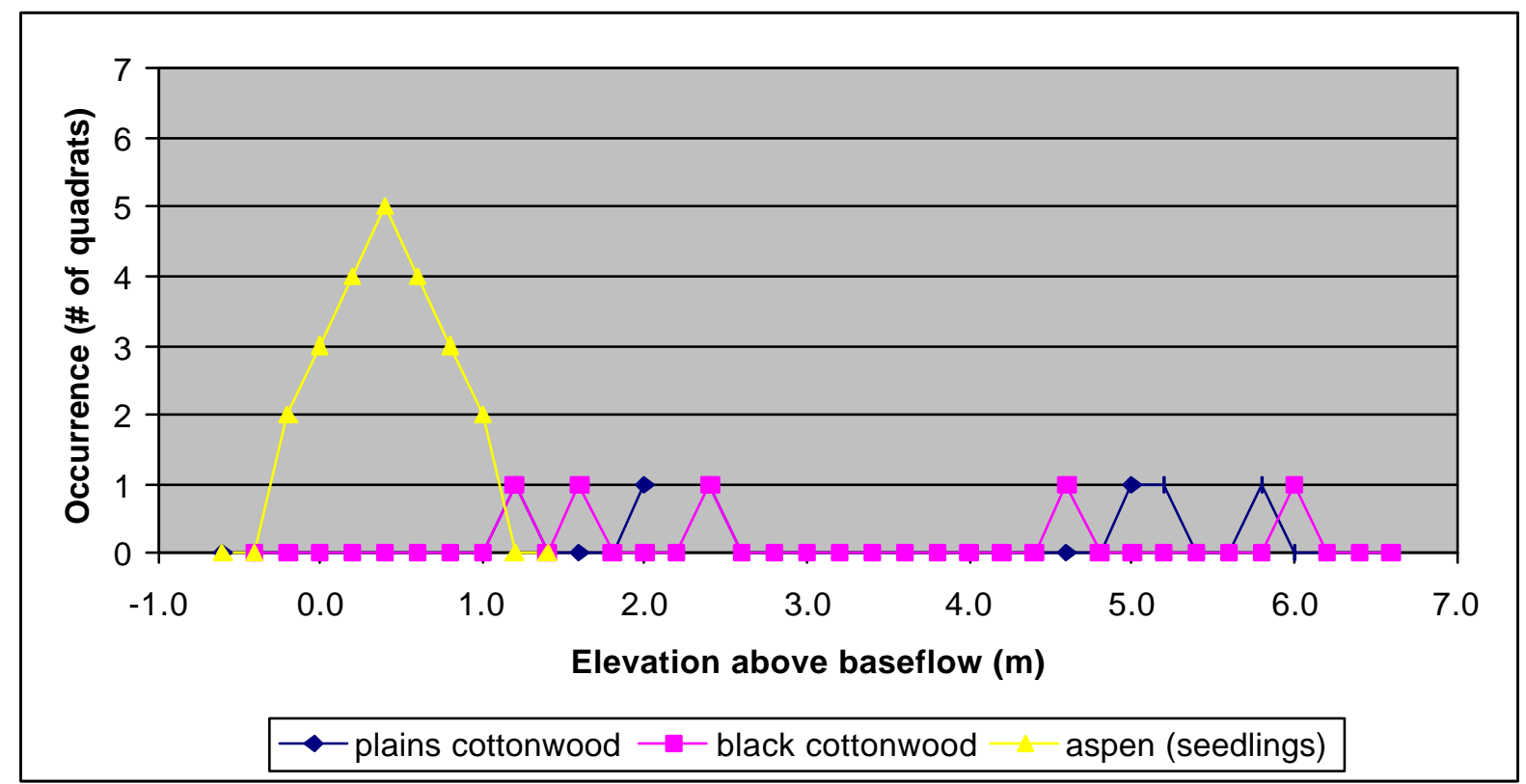

\subsubsection{Stand Health}

Cottonwood Stand Age: Nine mature trees were cored within this study reach, and ranged in age from 22 to 55 years (average of 33.1).

Cottonwood Recruitment: Some cottonwood seedlings were observed off transect at the river's edge, but none appear to survive scouring by winter flows.

Exotic Plants: Reed canary-grass is a dominant invasive species in this reach (Reed canary-grass is not an exotic, but a native species with a highly invasive life history). Common tansy and common plantain, the two most common herbs, are exotics. Thirteen of the twenty herbs recorded were exotics. Plains cottonwood (Populus deltoides) was planted in the Bonner's Ferry area in the early part of the century and now makes up a significant proportion of local cottonwood populations.

Noxious Weeds: We found no noxious weeds in this study reach. 


\subsubsection{SHORTIE'S ISLAND TO COPELAND BRIDGE STUDY REACH}

This reach contains several meander loops within the active channel where the dike was built across the neck of the meander loops. We completed 4 transects on point bars in this section. Appendix I includes photos of these sites.

\subsubsection{River bank profiles on the Copeland study reach.}

Elevation profiles for the four transects in this study reach $(0-50 \mathrm{~m})$ are provided below. In all cases there was a gentle gradient from the water level to the adjacent cottonwood stand and the dike.

Figure 41. Elevation profiles for transects in the Copeland study reach.

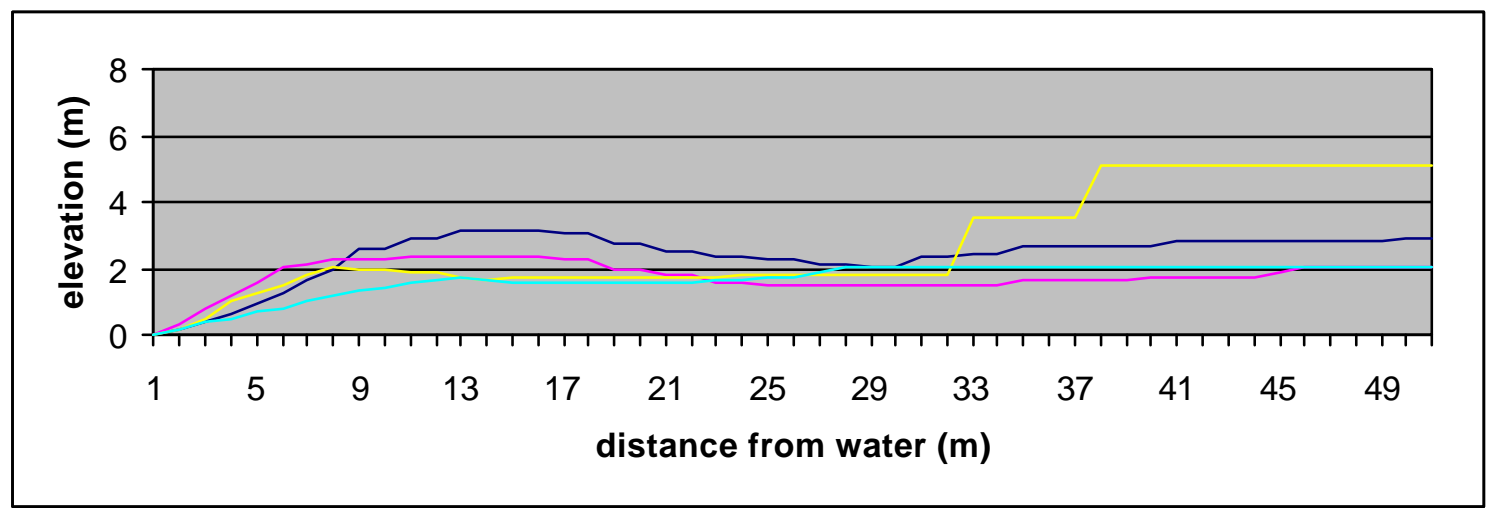

\subsubsection{River bank plant communities in the Copeland study reach.}

The grass community in this reach consisted of 3 annual and 14 perennial species. Reed canary-grass and redtop were the most important grass species (Figure 42). Among herbaceous forbs, we found 6 annual and 20 perennial species of which common tansy was the most prevalent (Figure 43). Woody shrubs were a minor component of the plant community. 
Figure 42. The distribution of grasses relative to September flows in the Copeland study reach.



Figure 43. The distribution of forbs relative to September flows in the Copeland study reach.

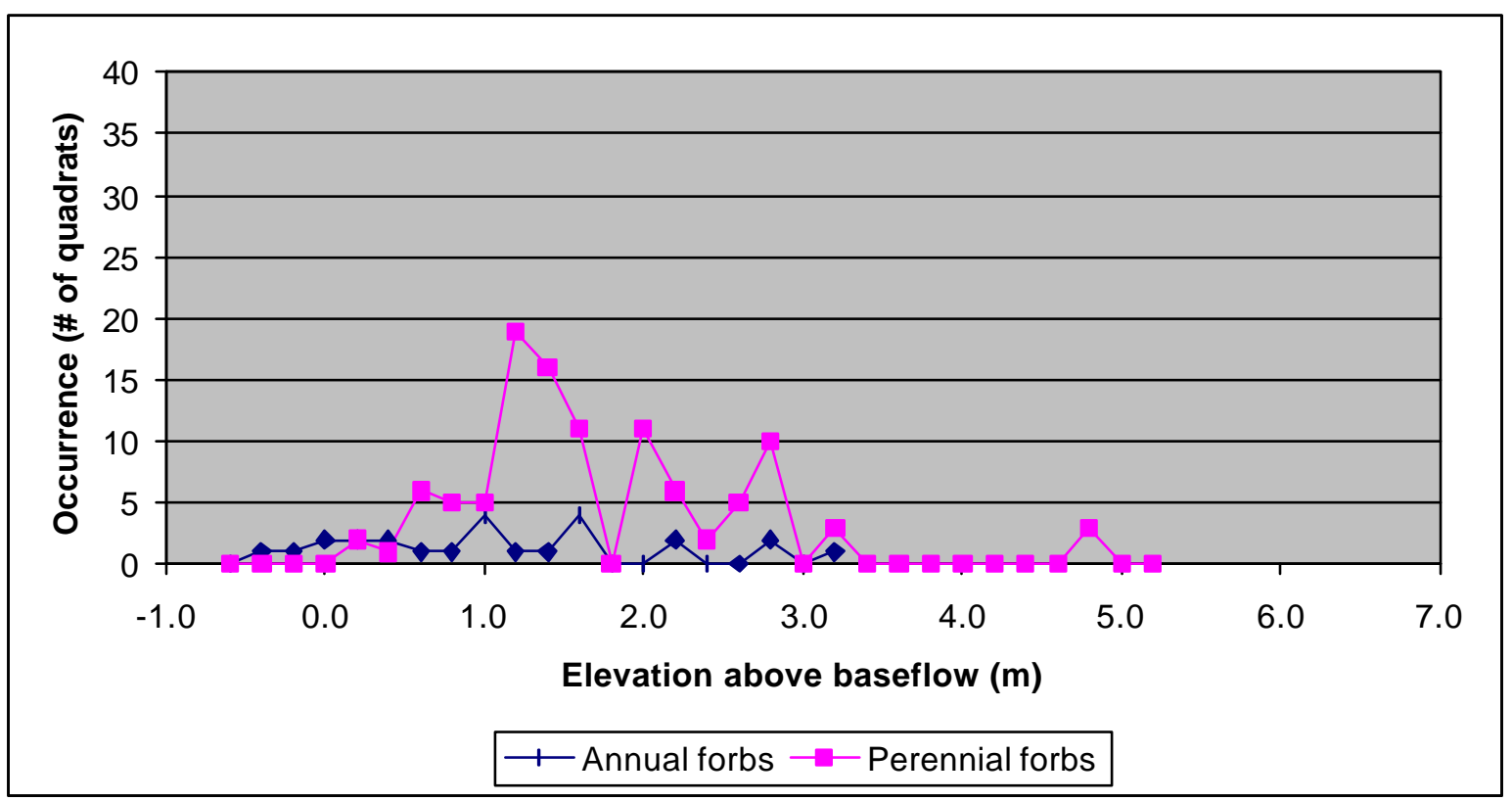




\subsubsection{The distribution of tree species by elevation.}

In this reach we found both seedlings and sapling stands of plains cottonwood (only 2 of 43 occurrences were black cottonwood). Aspen seedlings were also observed.

Figure 44. The distribution of tree species relative to September flows in the Copeland study reach.

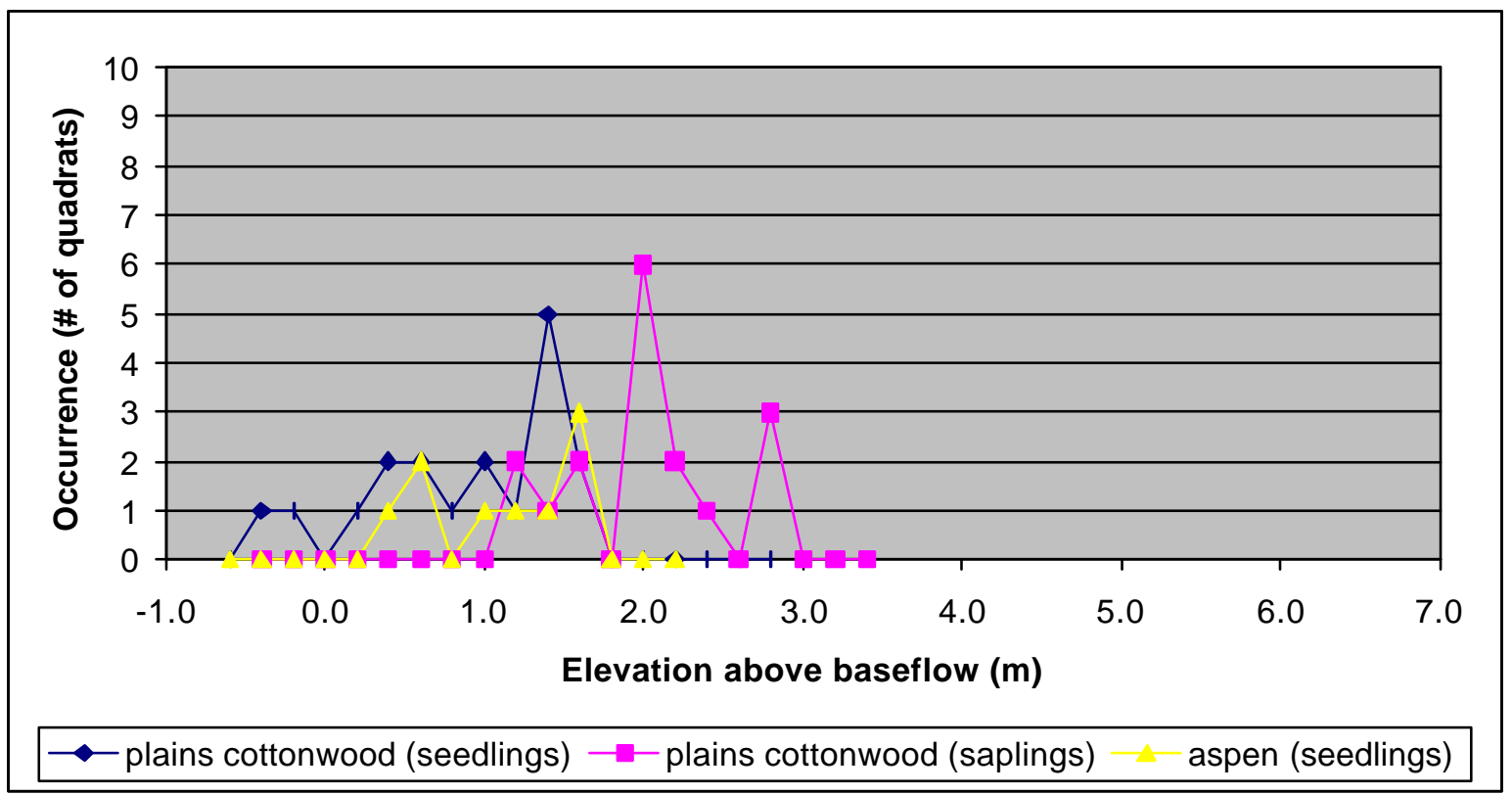

\subsubsection{Stand Health}

Cottonwood Stand Age: Nine cottonwoods were aged in this reach with an average age was 41.4 years. There was a significant difference in tree age between sites. . The Oxbow site ages varied from 25-40 years (average $=34.0(n=4)$ ). The point bar ages varied from $41-59$ years (average $=47.4(n=5))$ and consisted of scattered trees along the top and river side slope of the dike.

Cottonwood Recruitment: We found several patches ( $<1 \mathrm{ha})$ of cottonwood saplings of $3-5$ years of age on the oxbow site. The saplings were up to $2.5 \mathrm{~m}$ ( 8 feet) tall and are probably derived from root suckers. We also found seedlings of the year on both sites. Extensive seedling establishment was also observed on mud flats and bars along other parts of this reach. 
Exotic Plants: We found 5 of 18 species of exotic grasses and 13 of 26 species of exotic forbs. The two most common grasses were reed canary and redtop. The forb community was dominated by common tansy and Canada thistle, both of which are exotics. Cottonwood stands in this reach are dominated by plains cottonwood.

Noxious Weeds: Seven occurrences of spotted knapweed were recorded.

\subsubsection{COPELAND BRIDGE TO BORDER REACH}

This reach contains several small point bars and sites with riparian vegetation below the dike. Most of these sites were small $(<10 \mathrm{~h}$.). We did not establish transects in this reach.

\subsubsection{BORDER TO THE CONFLUENCE OF THE GOAT RIVER}

This reach is also severely restricted by dikes and contains few areas with riparian vegetation, except at the outflow of the Goat River. There are extensive stands of cottonwood on this outflow site. The original floodplain has been converted to agricultural use on both sides of the river for most of the reach; however a portion of the floodplain on the east side is maintained as wetland habitat (DU projects) on the Lower Kootenai Tribe reserve lands. Further downstream, there are extensive areas west of the river maintained as wetland and other habitats in the Creston Valley Wildlife Management Area. Cottonwood stands occur on the dikes and along the lower portions of Summit Creek where it runs through the CVWMA. Transects were not established in this reach.

\subsubsection{DUCK LAKE TO KOOTENAY LAKE STUDY REACH}

Near the south and upstream end of Duck Lake, the Kootenai River splits into two channels. There is no agriculture development on this section of the river. Large artificial wetlands and shallow lakes are maintained above the dike to the east (Duck Lake) and between the forks of the river (Six Mile Slough). This slough is bounded by natural levees with some dikes to maintain water levels in the slough for waterfowl habitat. This reach supports some larger stands of very large and old cottonwood along the dikes and in some cases, natural levees. Younger stands occur where sediment deposit has created scroll bars that extend out into Kootenai Lake We completed six transects on these bars on either fork of the Kootenai River where it flows into Kootenay Lake. Photographs of these sites are included in Appendix I. 


\subsubsection{River bank profiles.}

We completed 5 transects on the scrool bars that occur where the east and west channels of the Kootenai River flow into Kootenay Lake. These are low profile sites as indicated in Figure 45 below.

Figure 45. Elevation profiles for transects in the Kootenay Lake study reach.

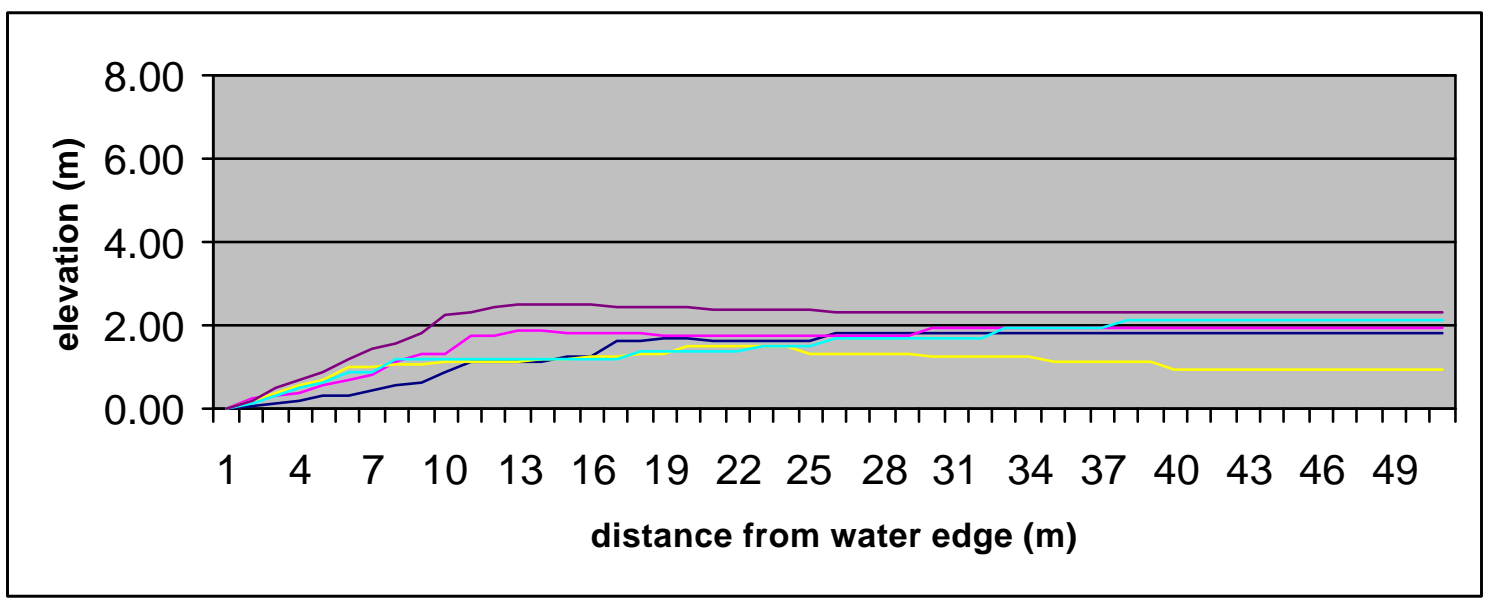

\subsubsection{River bank plant communities in the Kootenai Lake study reach.}

The grass community in this reach consisted of 2 annual and 8 perennial species . Reed canary-grass was the most important grass species (Figure 46). Among herbaceous forbs, 2 annual and 20 perennial species were recorded (Figure 47). Two woody shrubs and 4 willow species, (primarily coyote and pacific willow) were important from 1-2 $\mathrm{m}$ above base levels in Kootenay Lake (Figure 48). 
Figure 46. The distribution of grasses relative to September water levels in the Kootenay Lake, in the Kootenay Lake study reach.



Figure 47. The distribution of forbs relative to September water levels in Kootenay Lake, in the Kootenay Lake study reach.

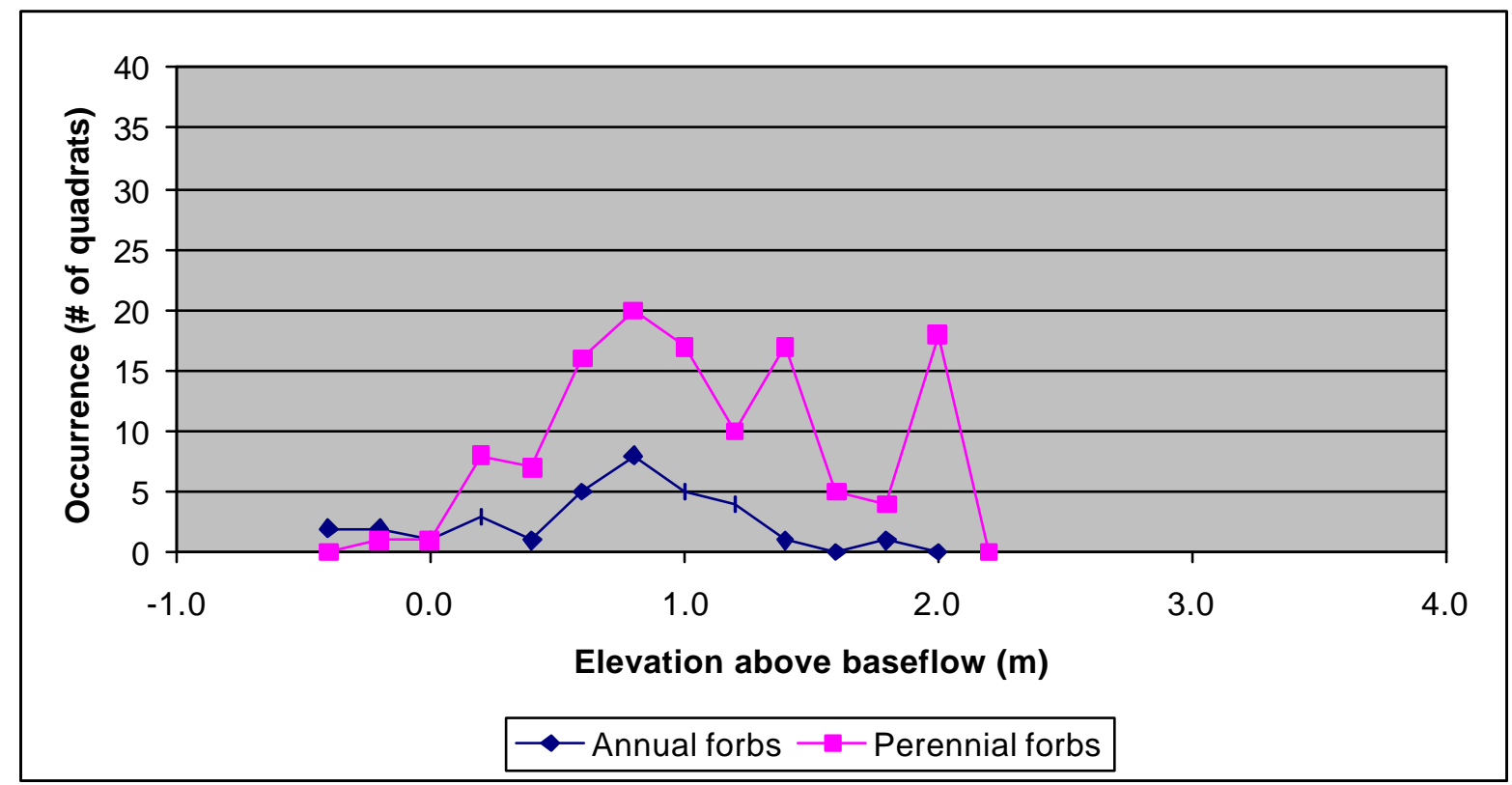


Figure 48. The distribution of woody shrubs species relative to September water levels in Kootenay Lake, in the Kootenay Lake study reach.

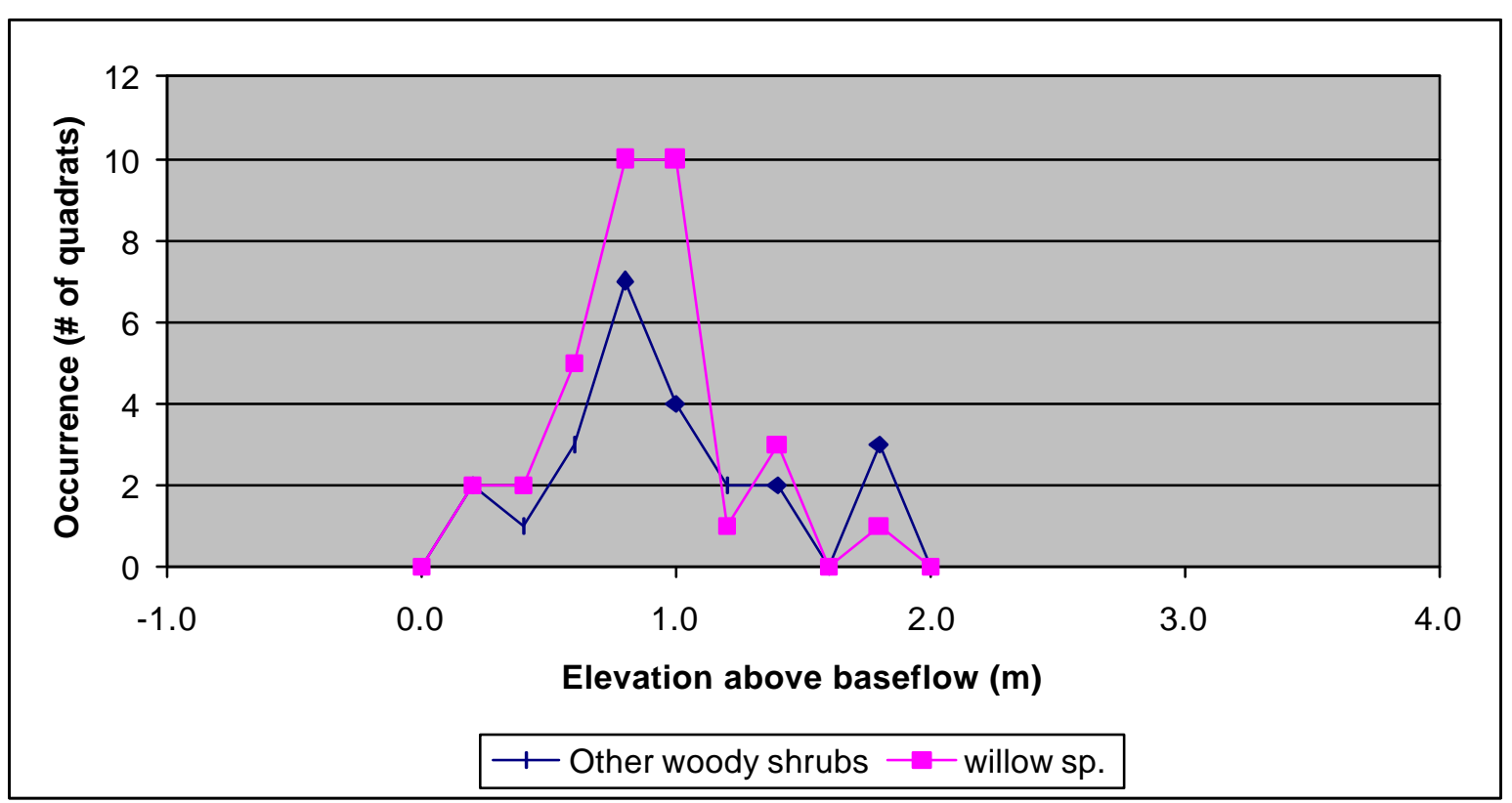




\subsubsection{The distribution of tree species by elevation.}

Cottonwood was the only important tree species found in this reach. A few green alder were recorded $(\mathrm{n}=5)$. We found cottonwood seedlings, saplings and mature trees (Figure 49). The mature cottonwood stands were $76.5 \%$ plains cottonwood $(n=34)$.

Figure 49. The distribution of tree species relative to September water levels in Kootenay Lake, in the Kootenay Lake study reach.

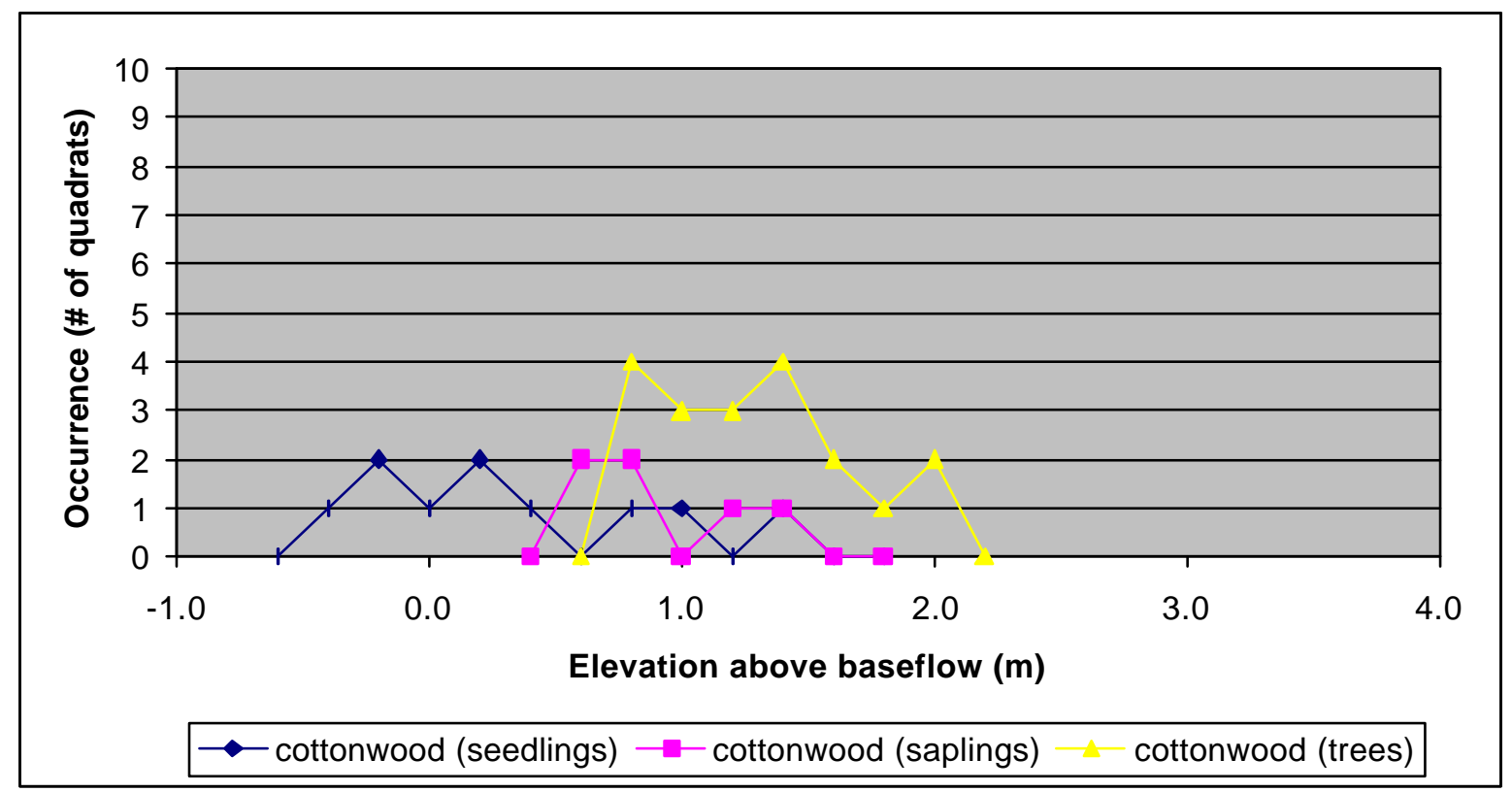

\subsubsection{Stand Health}

Cottonwood Stand Age: We aged 14 cottonwoods with an average age of 32.6 years. Most of the trees were 22 to 44 years of age. The stands were extensive, as indicated in the photos included in Appendix I. We found some very large plains cottonwood trees on and adjacent to transects on the west channel (1.1 to $1.60 \mathrm{~m}$ (3.8-5.6 feet)) dbh.

Cottonwood Recruitment: We found some cottonwood saplings (of both species) in this area and recent seedling establishment up to $1.3 \mathrm{~m}$ above the mean September level of Kootenay Lake. Dense stands of reed canarygrass occupied many sites and would have limited cottonwood establishment on two of the transect sites. There appear to be at least three generations of cottonwood recruitment that have established over the last 50-75 years along the point extending out into the lake from the east channel.

Exotic Plants: We found 5 of 10 species of grasses and 6 of 22 species of forbs that were exotics. Cottonwood stands in this reach are dominated by plains cottonwood.

Noxious Weeds: No noxious weeds were observed. 


\subsection{DISCUSSION}

\subsection{PRESENT STATUS OF RIPARIAN VEGETATION}

\subsubsection{SKOOKUMCHUCK TO WARDNER REACH}

We found that the upstream alluvial reach of the Kootenai River is in a relatively natural condition. Clearing for agriculture that occurred in earlier decades has now stabilized and there is relatively little human settlement on the floodplain. Cottonwood stands are not extensive, but occur throughout the reach. Natural fluvial processes are still operative in this reach and regular flood events are resulting in cottonwood and willow recruitment throughout the reach.

\subsubsection{WARDNER TO LIBBY DAM (INUNDATED REACH)}

This reach is inundated by the Libby Reservoir. Significant areas of alluvial floodplain and cottonwood stands occurred in the area flooded, primarily on the Canadian side and upstream of Rexford, Montana.

\subsubsection{LIBBY DAM TO MOYIE CONFLUENCE REACH}

This reach supported few cottonwood stands, due to the narrow floodplain in most of this reach.

\subsubsection{MOYIE CONFLUENCE TO BONNER'S FERRY REACH}

Most of the floodplain in this reach has been diked, however the river is unconstrained within the dikes. Large stands of mature cottonwood are present. Recruitment to cottonwood stands has occurred in recent years as a result of the spring flow releases for white sturgeon.

\subsubsection{BONNER'S FERRY TO KOOTENAY LAKE REACH}

Although this reach supported extensive cottonwood stands prior to white settlement, it has been extensively altered by diking and agriculture activities for almost all of its length. Some cottonwood recruitment has occurred on point bars below the dikes where the dikes cut across the neck of meander loops. These sites are found primarily in the Shortie's Island to Copeland bridge reach although some sites also occur from the Copeland bridge to the Canadian border. In Canada, there are significant cottonwood stands at the Goat River confluence and in parts of the CVWMA near the outflow of the Kootenai River into Kootenay Lake. At the outflow into Kootenay Lake, younger stands of cottonwood were present.

Exotic grasses and forbs occur throughout the system and there is no significant difference between their presence in the upper and lower portions of the river. However, reed canarygrass, an invasive native grass, may be affecting cottonwood and willow 
recruitment in the lower reaches. Its occurrence increased from $4.0 \%$ of grasses in the Wasa study reach to an average of $41.6 \%$ in the 4 reaches downstream of the Libby dam. Current patterns of flow regulation favor this species. Plains cottonwood were found downstream of Bonner's Ferry and made up 50\% of the stands studied in the Shortie's Island reach, $95.3 \%$ in the Copeland reach and $76.5 \%$ in the Kootenay Lake reach.

In all of the alluvial reaches below Libby dam, diking for agricultural use has severely restricted the active river floodplain. Within the remaining river floodplain however, regulated flows are the major determinant of the success of natural cottonwood recruitment.

\subsection{THE RELATIONSHIP BETWEEN FLOWS AND COTTONWOOD}

Our understanding of the dependence of riparian cottonwoods upon natural flow regimes has served as the basis for restoring floodplain forests along a number of regulated rivers in western North America. This restoration strategy involves application of the 'Recruitment Box Model' that quantifies the relationship between the recruitment of cottonwood seedlings and seasonal flow patterns (Mahoney and Rood 1998, Figure 50). The model provides managers with a tool for determining how seasonal flow releases can be coordinated with the limited periods of seed dispersal and seedling viability in cottonwoods.

The Recruitment Box aligns a position in both space and time with a riverbank elevation suitable for seedling establishment. The elevation requirements of seedlings, relative to base flows, have been quantified and are generally consistent (Mahoney and Rood 1998). Three research approaches were applied, including: (1) controlled-environment studies in which different water table patterns were provided and seedling responses observed, (2) field studies in which the elevation patterns of successful seedling cohorts were determined and (3) field studies in which seedlings were excavated to determine root lengths. On the basis of these studies, most cottonwood species appear to be able to colonize riverbank elevations from 60 to $150 \mathrm{~cm}$ above the late summer stream stage. Species with more vigorous seedlings, such as the Fremont cottonwood ( $P$. fremontii) and prairie cottonwood $(P$. deltoides), were able to colonize slightly higher zones, up to $250 \mathrm{~cm}$ above late summer stage. This higher riverbank elevation was due to a combination of more rapid growth rates and typically longer and warmer growing seasons of their native ranges that result in greater rooting depths (Kalischuk et al. 2001). 


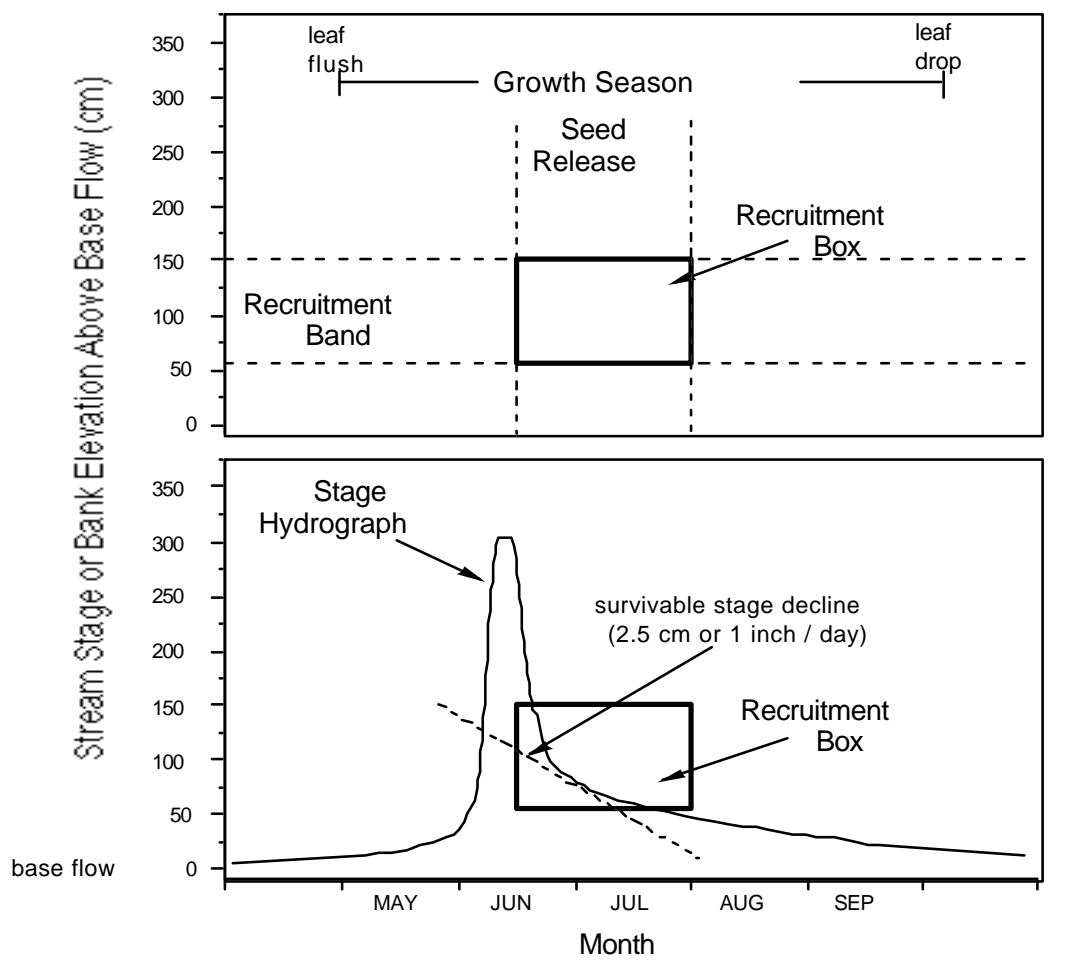

Figure 50. The Recruitment Box Model. The recruitment box defines a riverbank elevation in space and time where riparian cottonwood seedlings are likely to become established. The graphs represent seasonal phenology components (top), survivable rate of stage decline (middle) and a representative hydrograph that would satisfy requirements for seedling establishment (bottom). (modified from Mahoney and Rood 1998).

Another critical component of the seasonal hydrograph quantified by the Recruitment Box Model is the rate of stage recession (also referred to as the ramping rate), that cottonwood seedlings can survive. In most rivers in the west, river stage naturally declines abruptly right after the spring peak but subsequently recedes gradually through the summer. For successful seedling recruitment, the rate of recession of the moist zone must not exceed the potential rate of root elongation. Survivable ramping rates have been determined for a number of North American and European cottonwoods and substrate conditions (Barsoum and Hughes 1998, Mahoney and Rood 1998). Most researchers have found that cottonwoods can survive ramping rates of about 1 to $5 \mathrm{~cm}$ per day, although they may display slightly more vigorous growth with stage declines of $2.5 \mathrm{~cm}$ (1 inch) per day. Interestingly, these studies consistently indicate that the cottonwoods grow more vigorously with gradual rates of water table decline than with a constant water table level. This reflects not only their physiological tolerances but also their preference for the dynamic hydrologic conditions provided by natural riverine systems. 
The Recruitment Box model has been applied in restoration efforts on several North American Rivers, beginning in the early 1990's. Even though these rivers arise in regions with different environment gradients, relatively similar hydrograph patterns have been successful in promoting the recovery of riparian cottonwood forests. Along the Lower Truckee River in western Nevada, ramping rates have been varied from 1.25 to $2.5 \mathrm{~cm}$ per day through the 1990's (Rood and Gourley 1996). Following systematic recruitment flows, extensive groves of riparian cottonwoods $(P$. fremontii) have become established. These managed flows have also promoted the recovery of an endemic (and endangered) fish, the cui-ui sucker that occurs only in this river system as well as native cutthroat trout (Scoppettone and Rissler 1995). The Recruitment Box model has also been applied to the major tributaries of the Oldman River Basin in south western Alberta. In June of 1995 a widespread and heavy rain event resulted in the highest stream flows of record for the Oldman Basin. Following this exceptional peak flow, the initial flow recession was rapid but as the stream stage approached the upper zone of the recruitment box, ramping flows of $4 \mathrm{~cm}$ per day were imposed. This strategy resulted in prolific seedling recruitment $(P$. angustifolia, $P$. trichocarpa and $P$. deltoides) not only along the reaches immediately downstream from the dams but also further downstream as the tributaries combined to produce higher-order streams (Kalischuk et al. 2001). Initial seedling densities in late summer 1995 were often on the order of 100 per $\mathrm{m}^{2}$. Today, five-year old saplings as well as extensive clonal shoots from dispersed branch fragments and root suckers have dramatically reinvigorated the riparian woodlands along all of the regulated tributaries of the Oldman Basin (Rood and Mahoney 2000).

The management strategies applied in these areas demonstrate that the Recruitment Box Model provides managers with an effective tool for prescribing flow regimes (stage patterns) that will promote the recruitment of riparian cottonwoods.

\subsection{ANALYIS OF THE ANNUAL HYDROGRAPH AND COTTONWOOD RECRUITMENT ON THE KOOTENAI RIVER, 1991-2000.}

Starting in 1991, spring flows were manipulated in an attempt to produce flows below Bonner's Ferry that would stimulate white sturgeon spawning (USFWS 2000). Different types of flow releases were tested in each year. These flow releases allowed this project to examine the potential effects of springtime flow releases on cottonwood recruitment. The figures below for each year describe the stage or elevation at the gauge at Bonner's Ferry. This gauge is located where the river channel is relatively narrow due to diking that severely restricts the channel. As a result, changes in river stage associated with changes in flow are more extreme at this location than at the Moyie and Copeland transects sites where the channel and floodplain was wider. However, this data still permits us to make some generalizations about the potential for cottonwood recruitment under different flow regimes.

In 1991, fluctuations during the spring release did not produce conditions conducive to cottonwood recruitment (Figure 51). Winter flows up to $534.8 \mathrm{~m}$ (1754.5 feet) would 
have also removed any seedlings established below that level. Flow releases in 1992 and 1993 (Figures 52 and 53) were followed by winter releases that would have scoured any recruitment that might have occurred.

Figure 51. Daily elevation of the Kootenai River at Bonner's Ferry, 1991.

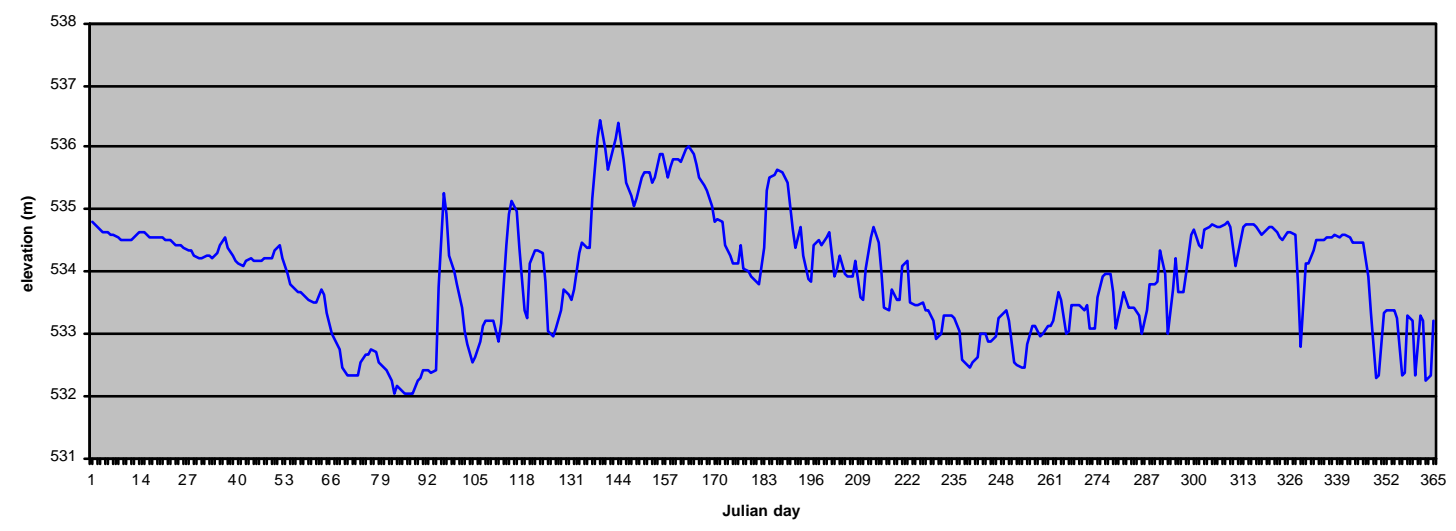

Figure 52. Daily Elevation of the Kootenai River at Bonner's Ferry, 1992.

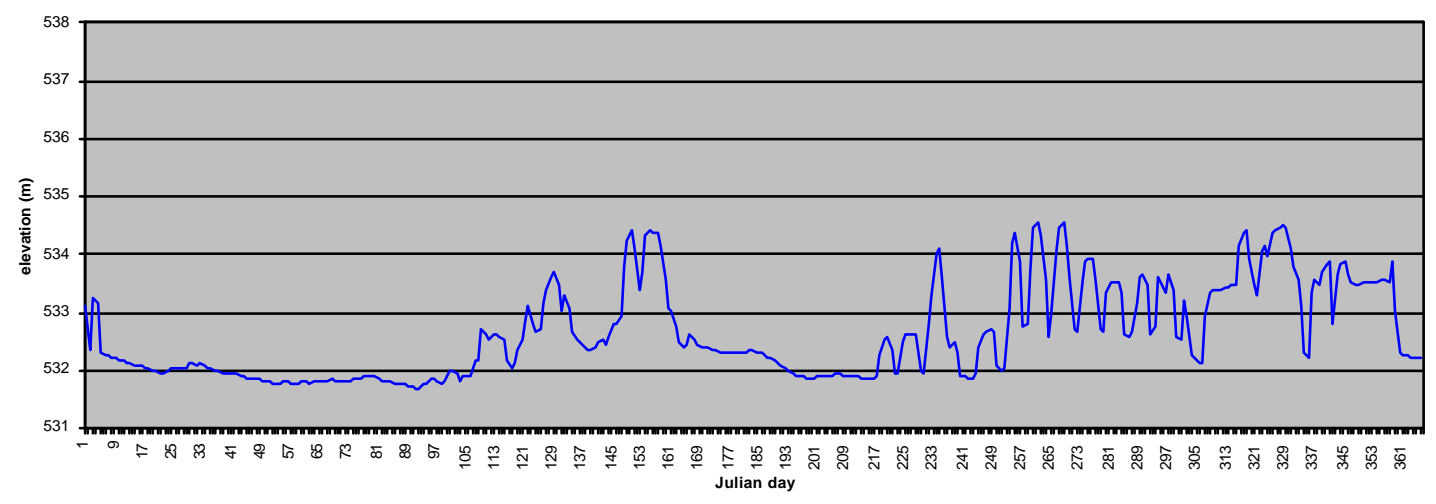

Figure 53. Daily Elevation of the Kootenai River at Bonner's Ferry, 1993.

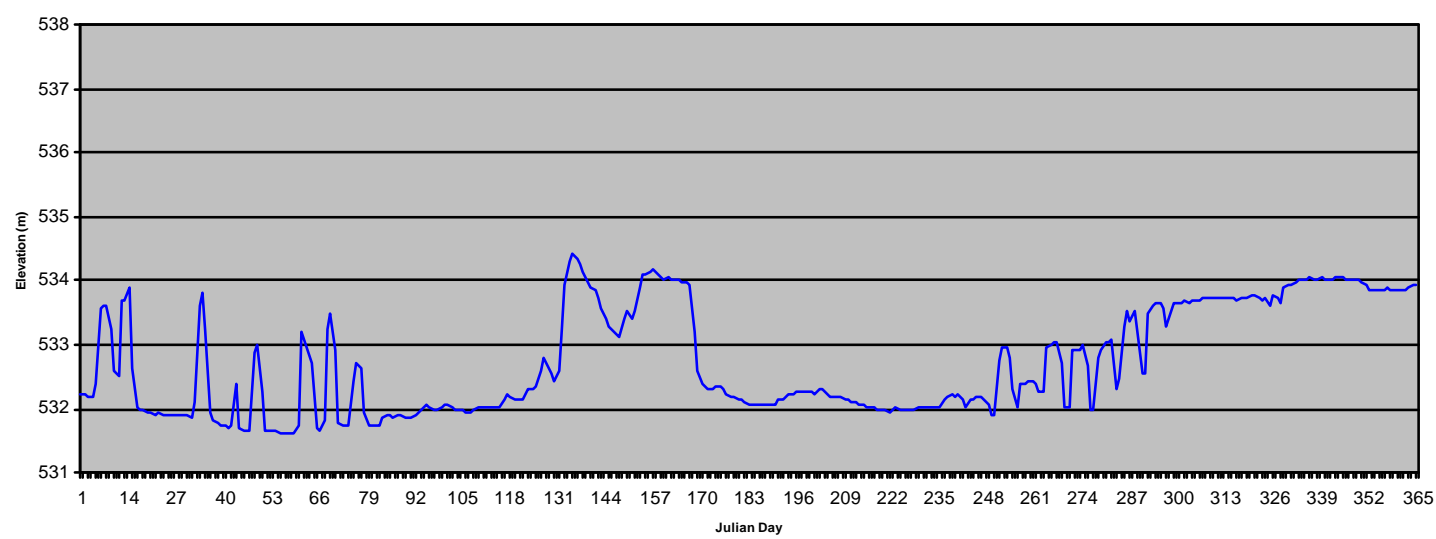


Spring flows in 1994 were low and any recruitment would have been scoured by subsequent flows in the fall of 1994 and the spring of 1995 (Figure 55). In 1995 spring flows were slightly higher, but were matched by fall and winter flows later in the year that would have scoured any recruitment sites.

Figure 54. Daily Elevation of the Kootenai River at Bonner's Ferry, 1994.

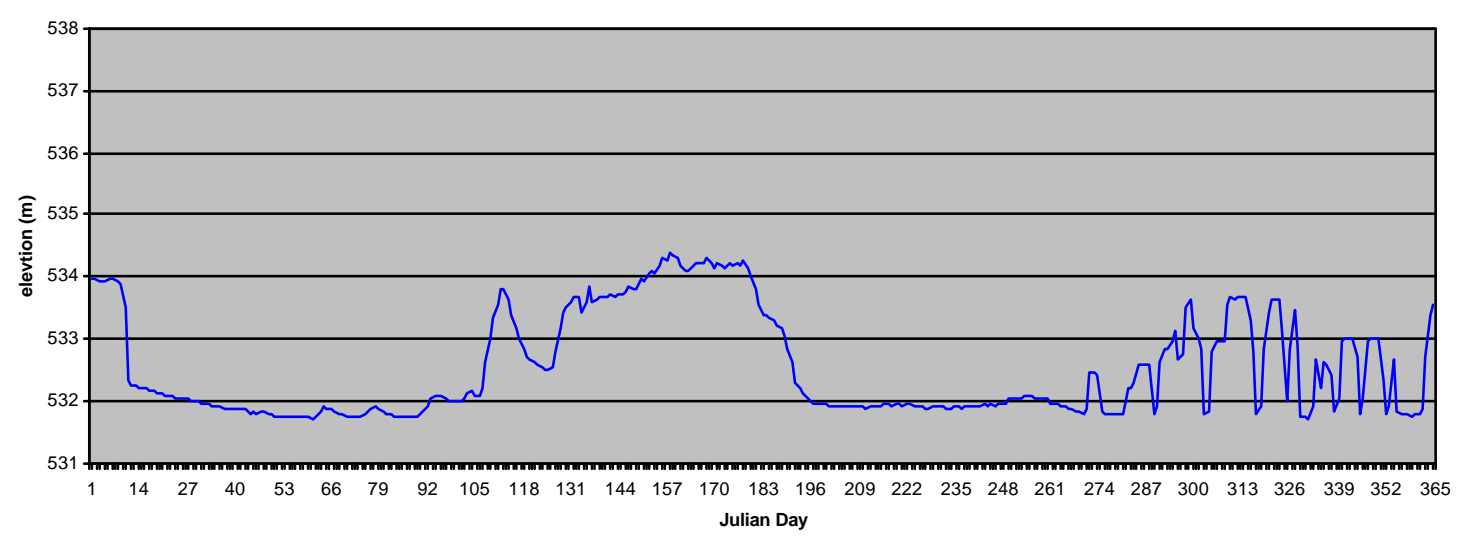

Figure 55. Daily Elevation of the Kootenai River at Bonner's Ferry, 1995.

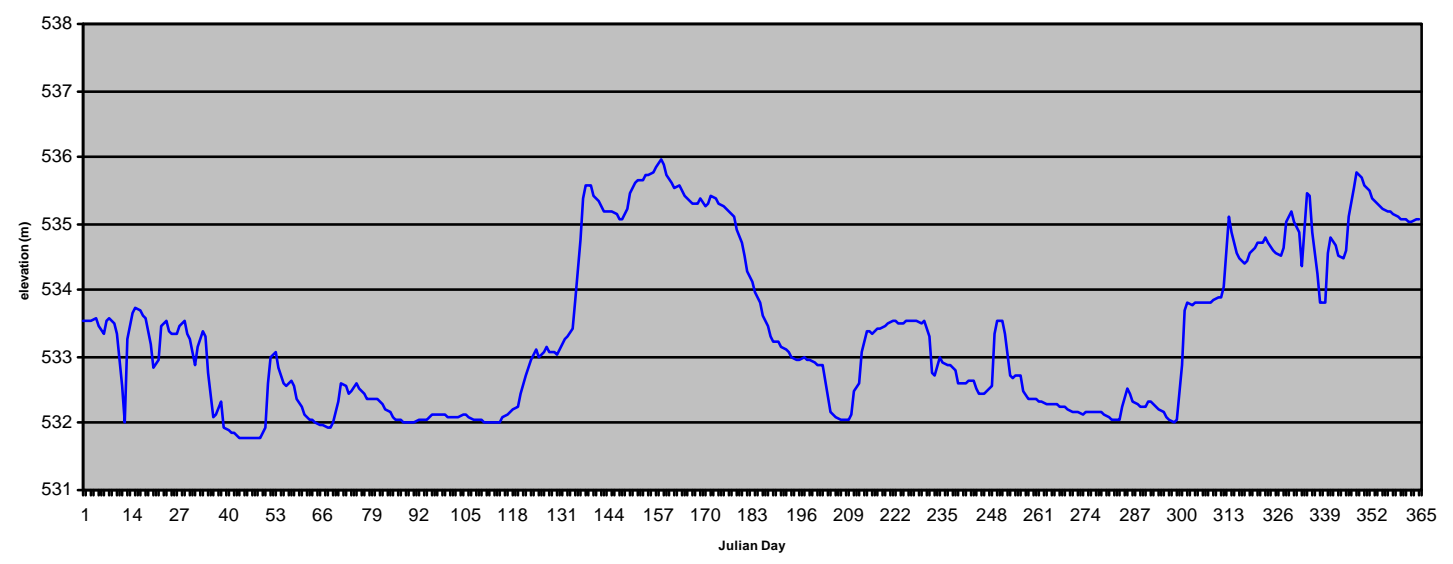


In contrast, releases in 1996 to 2000 achieved higher elevations (537.3 to $573.8 \mathrm{~m}$., 1760 1765 feet) and had recession limbs and early winter flows that were more conducive to cottonwood recruitment.

In 1996, spring flows peaked on June $10^{\text {th }}$ and declined slowly to relatively low summer, fall and winter flows (Figure 56). These flows could have resulted in recruitment, however high spring flows in the following year would like have curtailed any seedling establishment that occurred (Figure 57).

In 1997 spring flows were very high ( $>537 \mathrm{~m}$ ) and were followed, as in the previous year, by low summer, fall and winter flows. The rate of recession at the Bonner Ferry gauge was $9.52 \mathrm{~cm} /$ day for June 9 to July 14 (35 days). This rate of recession would have translated to a lower rate of recession at the Moyie and Copeland transect sites where the river channel is much wider. The rate of recession at these sites may still have been in excess of the $2.5 \mathrm{~cm} /$ day required for cottonwood recruitment, however the fine substrate (silt and sand) found on the two transect sites where extensive recruitment occurred, would have retained moisture more effectively than a cobble or gravel substrate and would have allowed establishment to occur at rates of recession above $2.5 \mathrm{~cm} /$ day (Amin and Rood 2001).

Spring flows in the following year (Figure 58), peaked quickly and probably did not scour recruitment. Conditions in this year could therefore have resulted in potential recruitment. This supposition is supported by the age of the saplings (3-5 years in the summer of 2000) we found on these transects.

\section{Figure 56. Daily Elevation of the Kootenai River at Bonner's Ferry, 1996.}

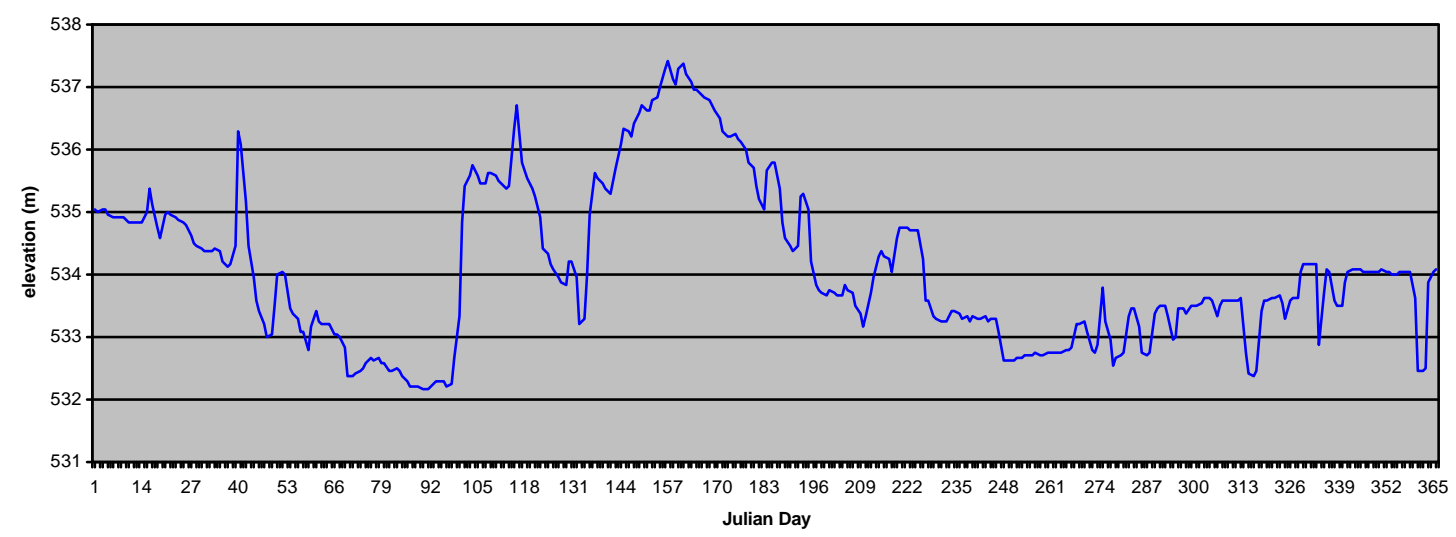


Figure 57. Daily Elevation of the Kootenai River at Bonner's Ferry, 1997.



Flow releases in 1998 may also have provided potential recruitment conditions (Figure 58 ), although in a narrower elevation range. The rate of decline was $3.38 \mathrm{~cm} /$ day for June 8-26 (14 days) at Bonner's Ferry.

Figure 58. Daily Elevation of the Kootenai River at Bonner's Ferry, 1998.

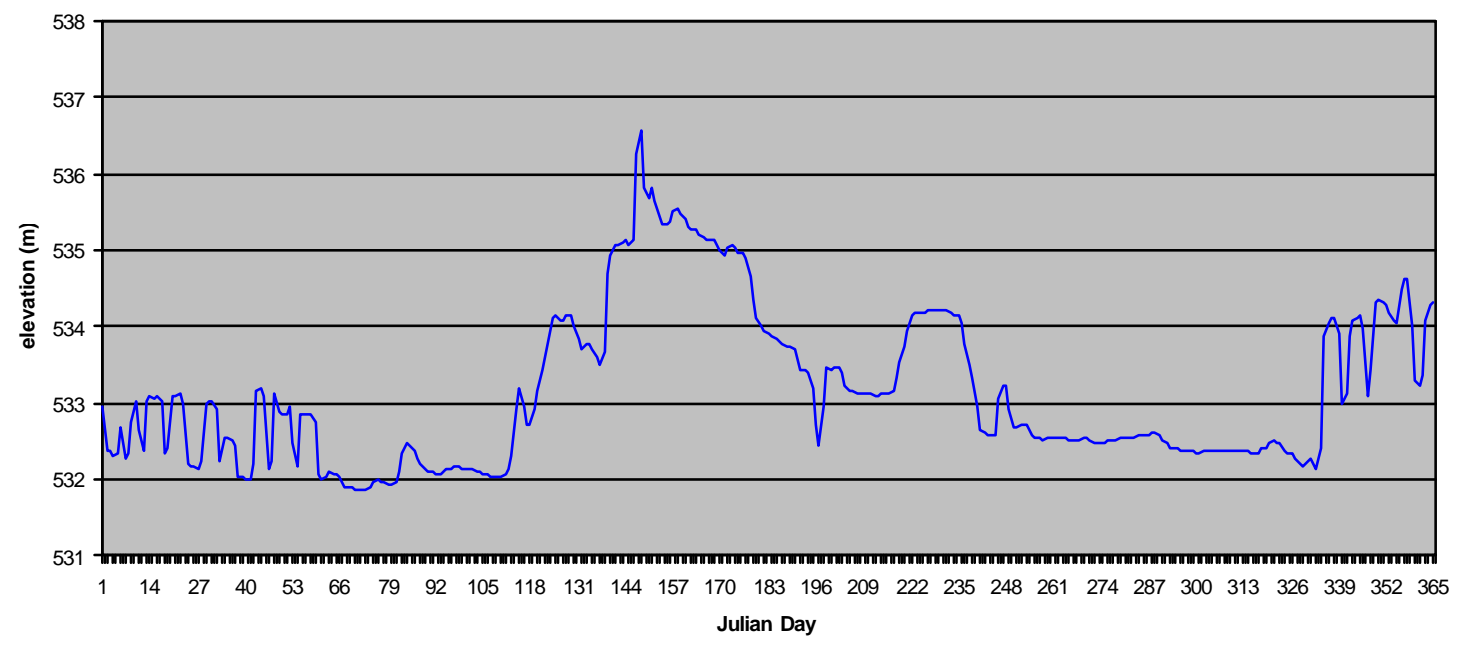


The hydrographs for 1999 and 2000 (Figures 59 and 60) also provide some options for recruitment, however recruitment in these years would not agree with the age of saplings found.

Figure 59. Daily Elevation of the Kootenai River at Bonner's Ferry, 1999.

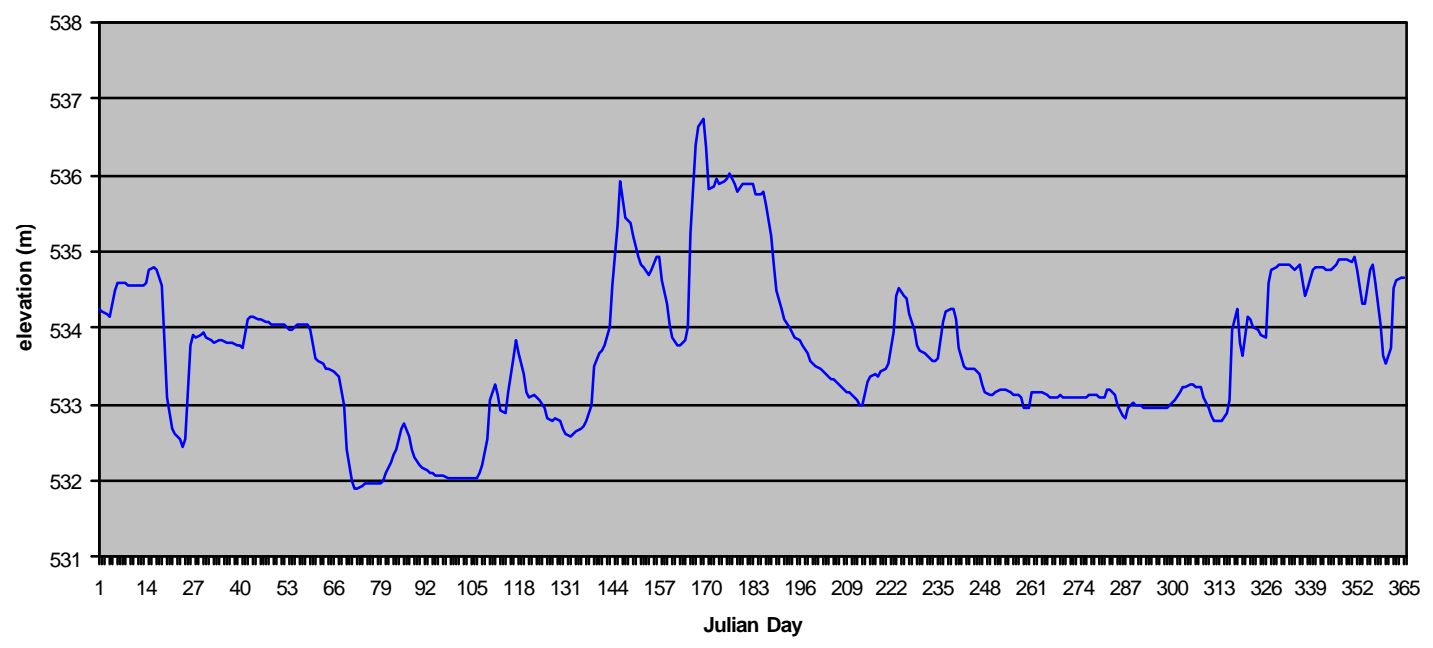

Figure 60. Daily Elevation of the Kootenai River at Bonner's Ferry, 2000.

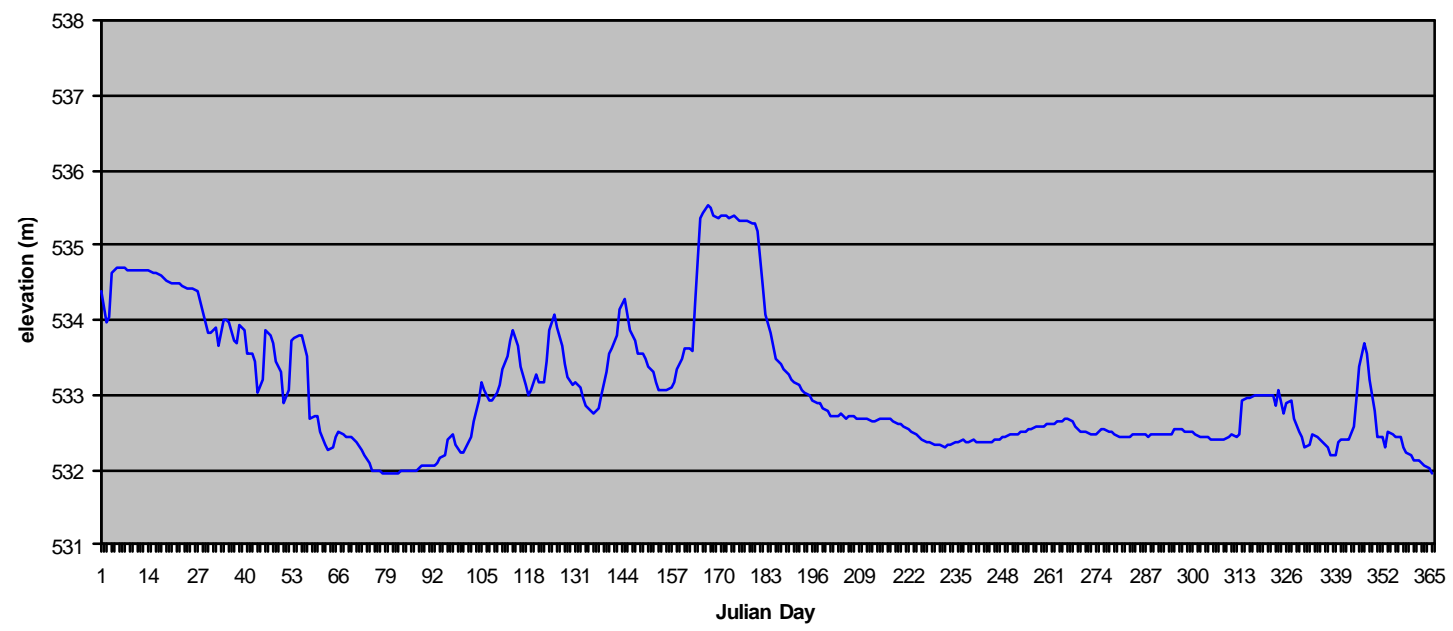

Based on this analysis, it would appear that the recruitment we observed was the result of the spring releases in either 1997 or 1998. These observations provides a clear demonstration of the effectiveness of spring flow releases to initiate recruitment to cottonwood stands on the Kootenai River below Libby Dam. 


\subsection{RECOMMENDATIONS}

\subsection{FLOW MANAGEMENT OPTIONS TO MAINTAIN RIPARIAN COTTONWOOD HABITATS BELOW THE LIBBY DAM.}

There are opportunities to manipulate flows to benefit cottonwoods in three reaches downstream of the Libby dam. Flows in these reaches are currently based on a very complex set of requirements for:

- high and variable flows in late fall and winter for power production and load following.

- varying spring flow targets to stimulate spawning in white sturgeon.

- more stable summer flows to maintain insect production and reduce predation of juvenile bull trout.

- burbot (ling cod) requirements for lower, more stable winter flows.

- Releases to provide water for salmon flow augmentation downstream in the Columbia River system.

- Releases to provide water for flushing of salmon smolts downstream in the Columbia River system.

- Limitations to high peak flows imposed by dike height and the potential erosion of dikes in the Bonner's Ferry to Kootenay Lake reach.

- An interest on the Canadian side in stabilizing levels in the Libby/Koocanusa Reservoir to maintain recreational fisheries values and aesthetic values in the Canadian portion of the reservoir.

- An interest in maintaining more stable water levels in Kootenay Lake, controlled by the Corra Linn dam below Nelson, B.C.

Most of these requirements are discussed in the Biological Opinion (USFWS 2000). This document also describes the flow management regime for Libby Dam from 2001 to 2003. The operating rules for this period are:

- Base flows will be maintained above $114 \mathrm{cms}$ (4000 cfs) year round.

- Spring flows (May 15 to June 15) will be maintained above $425 \mathrm{cms}$ (15,000 cfs). Maximum spring flows will be in the order of $1415 \mathrm{cms}(50,000 \mathrm{cfs})$ at Libby in order to remain below $1811 \mathrm{cms}(64,000 \mathrm{cfs})$ and a riverbank elevation of 537.7 m (1764 feet) on the dikes at Bonner's Ferry. Work presently underway by the Army Corp of Engineers and others may allow higher levels in the future, depending on what is learned about the impacts of high spring flow levels on dikes and adjacent farmland in the Bonner's Ferry and Creston areas. Prior regulations allowed flows to an elevation of $539.5 \mathrm{~m}$ (1770 feet).

- Summer flows (April to August) will be maintained above $255 \mathrm{cms}$ (9000 cfs) during average or higher water years. A sliding scale in the BiOp allows for lower minimum flows during dry years $(6,000 \mathrm{cfs})$.

- Fall and winter flows of up to $764 \mathrm{cms}(27,000 \mathrm{cfs})$ can be expected at Libby for power generation requirements. This results in flows of about $821 \mathrm{cms}(29,000$ cfs) at Bonner's with the additional flows from unregulated tributaries. These 
flows are variable but up and down ramping rates will be slower than has occurred previously based on limits imposed by the Biological Opinion (USFWS 2000).

All of these flow management criteria are subject to variations based on available flows and other requirements as described in the Biological Opinion 2000 (USFWS 2001).

The most important of these variables for cottonwoods are:

- Peak winter flows: Power requirements for high and variable flows in winter to maximize peaking capacity are not conducive to cottonwood recruitment. High winter flows would scour recently established seedlings and thus will limit the potential range of elevations for successful cottonwood recruitment downstream.

- Peak spring flows: Spring flow releases for white sturgeon will vary from year to year, based on water availability and as determined by USFWS white sturgeon team. This project is allocated a water budget (variable by year) of .4 to 1.6 million acre feet of storage that is available for release from the Libby Reservoir. There are two approaches to managing the flow releases associated with this water budget One approach would be to use the available water to achieve the highest peak flows possible for a short period and then quickly ramp down to lower river levels in order to stay within the allocated water budget. Another approach is to use the available water to create a lower peak flow and use the remaining volume to drop flows more slowly in order to more closely mimic normative spring flows. A variation on this strategy has been proposed that would tie flow releases to springtime inflows into the Libby reservoir, effectively mimicking the natural flow pattern of the river year to year (B. Moratz, pers. comm.). These latter strategies would be more conducive to cottonwood recruitment than the former.

- Rate of recession from peak spring flows: The degree to which slower declining flows can be incorporated into the flow management regime will dictate the success or failure in the recruitment of native cottonwood and willow. Cottonwood recruitment generally requires a decline in river stage immediately following the spring peak in the order of $2.5 \mathrm{~cm} /$ day, however, in cases of reaches dominated by fine substrates, seedlings may survive stage declines of up to 3 to 5 $\mathrm{cm} /$ day (Rood and Mahoney 2000).

- Summer flows: Stable or slowly declining summer flows help maintain cottonwood and willow seedlings established earlier in the year.

- Spring flows in the following two years: High spring flows in the years immediately following the successful recruitment of cottonwood and willow seedlings should be managed to minimize the scouring of these young seedlings. 
All of these requirements can be met by using the following strategy.

The longevity of cottonwoods (150- 200 years) is such that successful recruitment events every 10 to 20 years provide sufficient recruitment to maintain a balanced age class structure within riparian cottonwood stands. This requirement fits with the regular occurrence of high snow pack years in drainages of the Pacific Northwest. High snow pack years would result in larger than normal spring flows and water storage in the Libby reservoir. This additional storage could be used to generate large spring releases for sturgeon and other species and would provide the flexibility required to create a slowly declining recession limb in the annual hydrograph to provide for cottonwood recruitment. In many instances, a high flow year would be followed by lower flows in the subsequent water year, thus allowing recruitment to survive peak spring flows the following year.

Based on this discussion, we would propose the following as an objective for shaping spring releases to promote native cottonwood and willow recruitment downstream of Libby Dam.

\section{MANAGEMENT OBJECTIVE: In years with high snowpacks, spring flow releases at Libby dam should be managed such that the stage decline on point bars below Libby Dam is between 2 to $5 \mathrm{~cm}$ (1-4 inches) per day.}

This rate of stage decline should coincide with the seed release period (late May to early July) for cottonwood in downstream reaches, as defined by the recruitment box model. These releases should then be followed by one or two years of lower winter and springtime flows to allow seedling to properly root and establish.

This strategy would be particularly effective if the releases at Libby dam were shaped to take advantage of spring freshette in the downstream tributaries of the Fisher, Yahk, Moyie and other tributaries in order to produce a slowly declining hydrograph in alluvial reaches near Bonner's Ferry, where significant opportunities for cottonwood recruitment exist. In 1995, for example, there was a very "blocky" and quite unnatural release from Libby dam. Initially, there was a steep increase in flows over four days (May 12-16), followed by high and stable flows for 12 days and then a steep decline to lower flows over 4 days. (See Figure 8, p. 20, in the Recovery Plan for the Kootenai River Population of the White Sturgeon (USFWS 1999). However, this release, when combined with unregulated freshette contributions from the downstream tributaries, resulted in a hydrograph at Bonner's Ferry with a slowly declining limb from mid-May to early July.

The rates of stage decline proposed above may have been achieved in 1997 and 1998 at the transect sites in the Moyie and Copeland reaches. However we are currently unable to calculate the rates of stage recession for these reaches without additional river bank profile data. Therefore, a better understanding of floodplain elevations in the Moyie confluence to Kootenay Lake reach is needed to specifically define cottonwood and willow responses to future flow releases (see section 6.4). 
In total, we would suggest that the strategies proposed above will promote the recruitment of native cottonwood and willows effectively and integrate these requirements with the flow management criteria being applied to achieve other objectives on the Kootenai River.

\subsection{EXPECTED RESPONSE}

The likely response to this strategy in each of the three reaches below Libby dam, are indicated below.

\subsubsection{LIBBY DAM TO MOYIE REACH}

We would expect a minor response to flow changes in terms of area of recruitment since stands in this reach are limited. Recruitment may occur on point bars in the Libby to Troy section where the valley is wider than what occurs either upstream or downstream. Recruitment is this reach would depend on the hydrograph created by releases from Libby and the flows from the Fisher River.

\subsubsection{MOYIE CONFLUENCE TO BONNER'S FERRY REACH}

We would expect significant response to these releases in this reach, based on the braided character of the reach and the setback of the effective diking from the river bank in much of this reach. The short length of this reach $(7.5 \mathrm{~km})$ would limit the amount of recruitment that would occur, however, this reach supports most of the significant cottonwood stands remaining along the lower river on the US side and should thus be considered a management priority. This is also the only reach of the river where significant natural riparian process still occurs, providing a range of ecological functions (sediment transfer, channel change, creation of large woody debris etc.).

\subsubsection{BONNER'S FERRY TO KOOTENAY LAKE REACH}

Potential recruitment sites are limited in this reach due to the steep banks created by diking along most of the reach. Recruitment will occur on point bars where located below the dikes, as at the Copeland sites. Options in these areas are limited by winter flows, the winter elevations of Kootenay Lake on the lower portion of the river and by private land issues. There may be some long-term options depending on other actions and management strategies on conservation lands such as the Kootenai Wildlife Refuge, the Boundary Creek Wildlife Area and the CVWMA. Lands controlled by the Kootenai Tribe and Lower Kootenai Tribe at Creston may provide some opportunities on lands presently used for conservation purposes. 


\subsection{OTHER MANAGEMENT OPTIONS FOR MAINTAINING COTTONWOOD STANDS.}

There are relatively few areas where modifying regulated flows will result in rejuvenation of cottonwood stands along the lower Kootenai River. Planned flow releases for cottonwood will not come close to mitigating the massive impacts of past flow regulation and agriculture activities on riparian ecosystems in this system/sub-basin. Consideration should be given therefore, to other options for maintaining riparian cottonwood stands due to their importance to a wide range of fish and wildlife species, their critical role in maintaining ecological function in riverine systems and their former extensive distribution in this sub-basin, especially in the Moyie and Bonner's Ferry to Kootenay Lake Reaches.

There are 6 areas where action is possible and would be effective.

- Management of cottonwood on tributary confluence areas

- Plantings of willow and cottonwood stands

- Cattle and grazing management

- Acquisition and conservation easements

- Actions to maintain cottonwood stands in tributaries downstream of the Libby dam

- Actions to maintain cottonwood stands in upstream areas of the sub-basin.

A description of these options is included in Appendix III. 


\subsection{FUTURE STUDIES REQUIRED}

\section{MONITORING COTTONWOOD RESPONSE TO ALTERED FLOWS:}

Documenting the impact of future experimental flow releases on cottonwood and willow recruitment will require more detailed data on riverbank elevations and vegetation. This can be efficiently accomplished by working with other agencies working in this river basin. Detailed elevation data will be collected along the river in the summer of 2002 (G. Barton, pers. comm.), as part of USGS studies in the area related to the white sturgeon issue. Elevational profiles from the dikes or other structures defining the river channel will allow us to calculate rates of recession at specific locations along these reaches. We can then confirm the influence of past releases on young saplings and predict with greater precision those areas where recruitment is likely to occur, given different spring flows regimes in the future.

\section{MONITORING GEOMORPHIC AND VEGETATIVE RESPONSE TO}

ALTERED FLOWS: Past regulated flows and the recent spring releases in the last decade have altered the fluvial geomorphology of the river with subsequent impacts on both riparian vegetation and fisheries values. Work currently proposed by our study team on the Yakima and Middle Flathead rivers will provide a better understanding of these processes (Braatne et al. 2001) and will provide a good basis for understanding these processes on the Kootenai River. Future work on riparian vegetation should be coordinated with the work on the geomorphic aspects of the river system related to the white sturgeon recovery program and the project to restore ecological functions to the Lower Kootenai River sponsored by the Kootenai Tribes and funded by BPA,. The University of Idaho will be involved in these studies, including Dr. J. Braatne and others.

\section{DEVELOP A PLAN FOR THE MAINTENANCE OF RIPARIAN FUNCTION IN THE CANADIAN PORTION OF THE BONNER'S FERRY TO KOOTENAY}

LAKE REACH: In order to be effective, a tandem or parallel study is needed to look at restoring ecological function in the Canadian portion of the Bonner's Ferry to Kootenay Lake alluvial floodplain. Such a project should work closely with the work of the Kootenai Tribes and others on the US side. There are a range of fisheries issues that should be part of this work, especially when looking at options for developing off channel fish habitat. The objectives of such a project would be to:

- Provide an overview of cottonwood status in the Canadian portion of the reach. (Much more extensive stands occur here than on the US side).

- Develop options for maintaining riparian process and riparian vegetation in this reach.

- Look at options for maintaining cottonwood stands along the main river dikes, if it is demonstrated in the USGS work on the US side, that cottonwoods contribute to long term dike stability (or vice versa).

This should be a cooperative project involving the various Canadian management agencies, the Creston Valley Wildlife Management Area, the Lower Kootenay Band, the 
Columbia Basin Fish and Wildlife Compensation Program, the Columbia Basin Trust and others.

\section{DOCUMENT THE IMPACT OF THE INTRODUCTION OF PLAINS}

COTTONWOOD ON RIPARIAN VEGETATION IN THE BONNER'S FERRY

TO KOOTENAY LAKE REACH: Plains cottonwood now dominate riparian forest stands in the reaches below Bonner's Ferry. The potential impact of this introduction is not known and should be given consideration in future work.

\section{DOCUMENT THE LOSSES OF RIPARIAN HABITATS IN THE CANADIAN \\ PORTION OF THE LIBBY RESERVOIR: Losses of riparian habitats due to} inundation by the Libby Reservoir have been documented on the US side of the border, however no information is available for the Canadian portion of the reservoir area. Data for the Canadian side is required to develop an estimate of total losses and could be developed using pre-dam air photos and BC Forest Cover mapping for the pre-dam era.

\section{DEVELOP A RIPARIAN RESTORATION DEMONSTRATION PROJECT AT}

WARDNER, B.C.: With recent reductions in the range of the drawdown in Libby Reservoir, there is an extensive floodplain area at the head of the Libby reservoir where natural establishment of cottonwood and willow may occur if present reservoir levels are maintained over the long term. Water levels have been maintained an average of 20 feet below theoretical full pool over the last decade in response to a range of resource issues in the reservoir and downstream (B. Moratz, pers. comm.). BPA could consider a project to look at this site to see if natural recruitment is likely to occur in the exposed drawdown zone and then develop a plan for restoring cottonwood and willow, either naturally or though artificial plantings of cottonwood. The site is located on a major transportation corridor and would provide good profile for restoration work of this kind. 


\subsection{SUMMARY}

This work provides a basic understanding of the ecology of cottonwood stands and related riparian habitat types in the Kootenai River and provides an example of the benefits of cooperative, multi-disciplinary, ecosystem based research and management in an international sub-basin. We have found that there are good options for maintaining cottonwood stands on the lower reaches of this river by working with other interests on the river to develop a strategy for spring flow releases that will provide for cottonwood recruitment. More naturalized flows will provide benefits to a wide range of fish and wildlife species and related habitat elements such as riverbank willows and cottonwood forests. Continuing work in this area would fit well with the Kootenai Tribes riparian restoration project for this portion of the river. We expect to work closely with that group and others at the University of Idaho, to develop solid options for maintaining and enhancing riparian habitat along this river. 


\subsection{LITERATURE CITED}

Amin, N.A. and S.B. Rood. 2001. Inundation tolerances of riparian willows and cottonwoods. Journal of the American Water Resources Association (In press).

Auble, G.T., J.M Friedman and M.L. Scott. 1994. Relating riparian vegetation to present and future streamflows. Ecol. Appl. 4:544-554.

Barsoum, N. and F.M.R Hughes. 1998 Regeneration response of black poplar to changing river levels. In: Hydrology in a changing environment. British Hydrological Society, Vol. I:397-412.

Boundary County Historical Society 1987. The History of Boundary Country, Idaho. Taylor Publishing Comp., Portland Or.

Braatne J.H., S.B. Rood, and P.E. Heilman. 1996. Life history, ecology and conservation of riparian cottonwoods in North America. In: Biology of Populus and its implications for management and conservation, R.F Stettler, H.D. Bradshaw, Jr., P.E. Heilman, and T.M. Hinckley (eds). NRC Research Press, National Research Council of Canada, Ottawa, Canada. Pp. 57-85.

Braatne J.H., B. Jamieson and M. Lorang. 2001. The impact of flow regulation on riparian cottonwood ecosystems in the Yakima River Basin. Stage 2. Proposal to the Col. Plateau funding process. Available at www.cbfwf.org .

Bradley C., and D. Smith, 1984. Meandering Channel Response to Altered Flow Regime: Milk River, Alberta and Montana., Water Resources Research, 20: 1913-1920.

Bradley C., and D. Smith, 1986. Plains Cottonwood Recruitment and Survival on a Prairie Meandering River Floodplain, Milk River, Southern Alberta and Northern Montana, Canadian Journal of Botany, 64: 1433-1442.

Bradley C.F., F. Reintjes, and J. Mahoney, 1991. The Biology and Status of Riparian Poplars in Southern Alberta, World Wildlife Fund Canada and Forestry, Lands \& Wildlife, Fish and Wildlife Division, pp. 85 .

Clayton, S.R, B.J Moynahan, T.G. Parker and T.R. Weisenburger, W.H. Thompson and P.L. Hansen, 1998. Upper Clark Fork River Streambank Stabilization Pilot Study. Excerpts from Report, Univ. of Montana. Available at: www.rwrp.umt.edu/projects.

DeFrancesco, D. 2001.Factors influencing Black Cottonwood (Populus tricocarpa) recruitment on the Upper Clark Fork River, western Montana. Univ. of Montana. Abstract of report available at: www.rwrp.umt.edu/projects.

Dennington, M. 1996. History of Diking on the Kootenay Riever Floodplain in British Columbia. By: Redwing Consultants, for: Dept of Fisheries and Oceans, Ottawa. 27p.

Farwell, A.S. 1883. The Kootenay Reclaimation Scheme. In: The Resources of British Columbia.

Fenner P., W. Brady, and D. Patton, 1985. Effects of Regulated Water Flow on Regeneration of Fremont Cottonwood, J. of Range Management 38: 135-138.

Goldsmith, F.B., CM. Harrison and A.J. Morton. 1986. Description and analysis of vegetation. In: P.D. Moore and S.B. Chapman (Ed), Methods in Plant Ecology. Wiley \& Sons, New York: 437-524. 
Jamieson, B., E.B. Peterson, N.M. Peterson and I. Parfitt. 2001. The conservation of hardwoods and associated wildlife in the CBFWCP area in southeastern British Columbia. Prepared for: Columbia Basin Fish and Wildlife Compensation Program, Nelson, B.C. By: BioQuest International Consulting Ltd. and Western Ecological Services. Available at www.cbfwcp.org

Jamieson, B. and G. Allen. 1997.Elk Valley riparian assessment. Prep. for Columbia Basin Fish and Wildlife Compensation Program, Nelson, B.C. 118 p.

Jamieson, B. and E Hennan. 1998. The Columbia wetlands wildlife management area: Operational Plan 1998-2002. Prep. for B.C. Min. Environ, Lands \& Parks, Wildl. Br., Land Manage. Section, Cranbrook, B.C.

Jamieson, B. and J. Braatne. 2001. The Impact of flow regulation on riparian cottonwood ecosystems: Interim Progress Report, May 2001. BioQuest International Consulting Ltd.

Johnson, W.C. 1992. Dams and riparian forests: Case study from the upper Missouri River, Rivers, 3: 229242 .

Johnson, W.C. 1994. Woodland Expansion in the Platte River, Nebraska: Patterns and Causes. Ecological Monographs. 64: 45-84.

Johnson W.C., R.L. Burgess, and W.R. Keammerer, 1976. Forest Overstory Vegetation and Environment on the Missouri River Floodplain. Ecol. Monogr. 46: 58-84.

Johnson, R.R.; Jones, D.A. 1977. Importance, preservation and management of riparian habitat: a symposium. July 9, 1977, Tucson, Ariz. USDA For. Serv., Rocky Mtn For. Range Exp. Sta. and U.S. Nat. Park Serv. 217 p.

Johnson, W.C., T.L. Sharik, R.A. Mayes and E.P. Smilth. 1987. Nature and cause of zonation discreteness around glacial prairie marshes. Can. J. Bot 65:1622-1632.

Johnson, W.C., M. Dixon, G. Larson and R. Simons. 1992. Riparian vegetation along the Snake River, Idaho, below Swan Falls Dam: past, present and future. Report to Idaho Power Company and the U.S. Fish and Wildlife Service.

Johnson, W.C., M.D. Dixon, R. Simons, S. Jenson and K. Larson. 1995. Mapping the response of riparian vegetation to possible flow reductions in the Snake River, Idaho. Geomorphology 13:159-173.

Kalischuk, A. R., S.B. Rood and J.W. Mahoney. 2001. Environmental influences on seedling growth of cottonwood species following a major flood. Forest Ecology and Management (in press).

Knudson, K. 1994. Water quality status report: Kootenay (Kootenai) River Basin British Columbia, Montana and Idaho. Kootenai River Network. Libby, MT. and Ecological Resource Consulting, Helena, MT. 57 pp.

Mahoney, J.M. 1996. How Rivers Affect the Establishment and Growth of Riparian Poplars. PhD. thesis, University of Calgary, Calgary, Alberta, pp .

Mahoney, J. M. 1997. Incorporating downstream ecosystem concerns into reservoir operations in southwestern Alberta, Canada. Wetlands Conf.. Soc. of Wetland Scientists. Bozeman, Nt. P 86.

Mahoney, J. M. 1997a. Streamflow Requirements for Cottonwood Seedling Recruitment-A Interative Model. Wetlands Dec 1998 Volume 8 pages 634-645. 
Mahoney J.M., and S.B. Rood, 1991. A device for studying the influence of declining water table on poplar growth and survival, Tree Physiology, 8: 305-314.

Mahoney J.M., and S.B. Rood, 1992. Response of a hybrid poplar to water table decline in different substrates, For. Ecol. Manage. 54: 141-156.

Mahoney J.M., and S.B. Rood, 1998. Streamflow Requirements for Cottonwood Seedling Recruitment-A Integrated Model. Wetlands 8:634-645.

Marotz, B. et al. (9 authors) 2000. Kootenai River Subbasin Summary: Draft, Sept. 29, 2000. Prepared for the NWPPC. 124 pp.

Martin, R.C. and H. J. Jerome 1993. Pallisades Wildlife Mitigation: South Fork Snake River Programmatic Management Plan: Implementation Phase I. Idaho Dept' of Fish and Game. For: US Dept of Energy, BPA, Portland, Or. 26p.

Muller-Dombois, D. and H. Ellenberg. 1974. Aims and methods of vegetation ecology. Wiley and Sons, New York.

Nisbet. J. 1994. Sources of the River: Tracking David Thompson across Western North America. Sasquatch Books, Seattle.

Polzin, M.L. and S. B. Rood 2000. Effects of Damming and Flow Stabalization on Riparian Processes and Black Cottonwoods along the Kootenay River. Rivers: Vol. 7, No. 3. p.

Rood, S.B. 1995. Cottonwoods along the Columbia River and potential impacts of river stage decline downstream from the Keenleyside dam, B.C. Univ. of Lethbridge, Alta.

Rood S.B., and S. Heinze-Milne, 1989. Abrupt Downstream Forest Decline Following River Damming in Southern Alberta. Can. J. Bot. 67: 1744-1749.

Rood S.B., and J.M. Mahoney, 1990. Collapse of Riparian Poplar Forests Downstream from Dams in Western Prairies: Probable causes and Prospects for Mitigation, Environmental Management, 14: 451-464.

Rood S.B., and C. Bradley, 1993. Assessment of Riparian Cottonwoods along the Bow River Downstream from Calgary, Alberta, Prepared for: Trout Unlimited Canada, Department of Biological Sciences. University of Lethbridge Alberta, pp. 63.

Rood, S.B., and J.M. Mahoney, 1995. River Damming and Riparian Cottonwoods Along the Marias River, Montana. Rivers 5: 195-207.

Rood S.B., J.M. Mahoney, D.E. Reid, and L. Zilm, 1995. Instream Flows and the Decline of Riparian Cottonwoods Along the St. Mary River. Can. J. Bot. 73:1250-60.

Rood S.B. and C. Gourley, 1996. Instream flows and the restoration of riparian cottonwoods along the lower Truckee River, Nevada. Report prepared for the US Fish and Wildlife Service and The Nature Conservancy, Reno, NV. pp. 27.

Rood S.B. and A. Kalischuk, 1998. Cottonwood seedling recruitment following the flood of the century of the Oldman River, Ablerta, Canada. Wetlands (In press).

Rood, SB and Mahoney, JM. 2000. Revised instream flow regulation enables cottonwood recruitment along the St. Mary River, Alberta. Rivers 7(2): 109-125. 
Scoppettone, G.G. and R.H. Rissler. 1996. Endangered cui-ui of Pyramid Lake, Nevada. P. 322-324, In: Our living resources: a report to the nation on the distribution and abundance and health of US plants, animals and ecosystems. Ed. E.T. LeRoe, G.S. Farris, Dept of Interior, NBS, Wash. D.C.

Scott, D. and E. Hanic. 1974. East Kootenay Chronicle. Mr.Paperback, Langley, B.C.

Scott, M.L., G.T. Auble, J.M. Friedman, L.S. Ischinger, E.D. Eggleston, M.A. Wondzell, P.B. Shafroth, J.T. Back, and M.S. Jordan 1993. Flow recommendations for maintaining riparian vegetation along the Upper Missouri River, Montana. National Biological Survey, National Ecology Research Center, Fort Collins, $\mathrm{CO}$.

Scott M.L., J.M. Friedman, G.T. Auble, 1996. Fluvial Process and the Establishment of Bottomland Trees, Geomorphology 14: 327-339.

Segelquist C.A., M.L. Scott and G.T. Auble, 1993. Establishment of Populus Deltoides Under Simulated Alluvial Groundwater Declines. Am. Midl. Nat. 130: 274-285.

Snyder W.D., and G.C. Miller, 1991. Changes in Plains Cottonwoods along the Arkansas and South Platte Rivers Eastern Colorado, Prairie Nat. 23: 165-176.

Snyder, E.B. and G.W. Minshall. 1996. Ecosystem metabolism and nutrient dynamics in the Kootenai River in relation to impoundment and flow enhancement for fisheries management. Final Report. Stream Ecology Center, Idaho State University, Pocatello, ID.

Stromberg J.C., and D.T. Patten, 1992. Mortality and Age of Black Cottonwood Stands Along Diverted and Undiverted Streams in the Eastern Sierra Nevada, California. Madrono 39: 205-223.

Stromberg J.C., and D.T. Patten, 1991. Instream Flow Requirements for Cottonwoods at Bishop Creek, Inkyo County, California. River 2: 1-11.

U.S. Department of Agriculture, 1914. Land Classification of the Pend Oreille National Forest. Available at the Museum of North Idaho in Coeur d'Alene, Idaho.

US Fish and Wildlife Service. 1999. Recovery Plan for the White Sturgeon (Acipenser transmontanus): Kootenai River Population. US Fish and Wildlife Service, Portland, OR. 96p.

US Fish and Wildlife Service. 2000. Biological Opinion: Effects to Listed Species from Operations of the Federal Columbia River Power System. 106 p.

Yde, C.A. and A. Olsen. 1984. Wildlife impact assessment and summary of previous mitigation related to hydroelectric projects in Montana: Vol. 1. Libby Dam Project. Montana Dept Fish, Wildl. \& Parks, Kalispell, Mon. 91 p. 


\subsection{APPENDICES}

(These appendices are provided as separate files on the bpa website)

Appendix I. Photographs of transect sites in each study reach.

Appendix II. Historic and recent photographs, mapping and aerial photographs of the Kootenai River floodplain near the US/Canada border.

Appendix III. Other management options for maintaining cottonwood stands along the Kootenai River. 


\section{APPENDIX I. PHOTOGRAPHS OF TRANSECT SITES.}

Photographs are provided below for several of the transect sites surveyed in this study.



Figure 1. Mature cottonwood and willow/cottonwood recruitment on a point bar in the Wasa Study reach. 


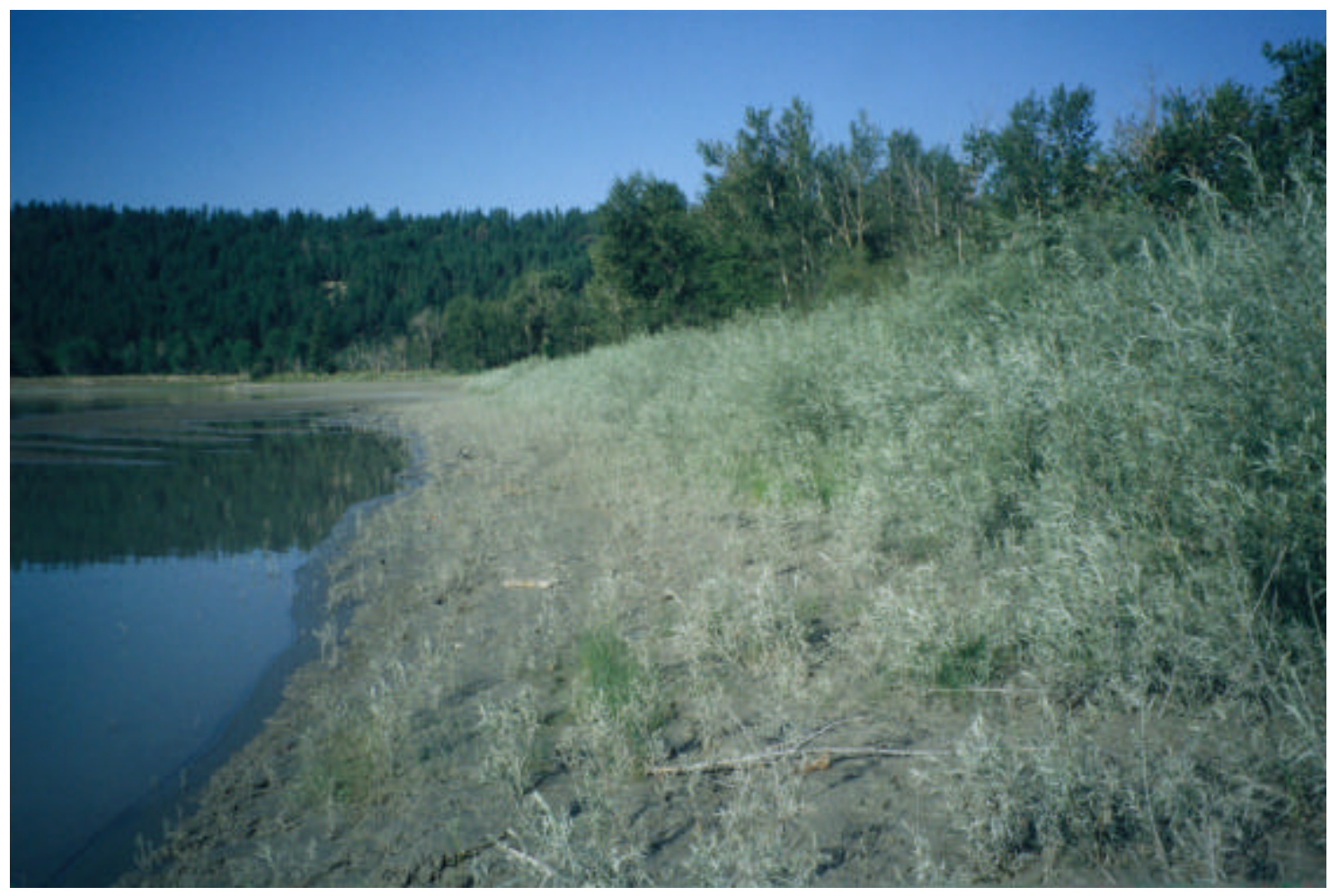

Figure 2. Willow recruitment on a point bar in the Wasa study reach. 


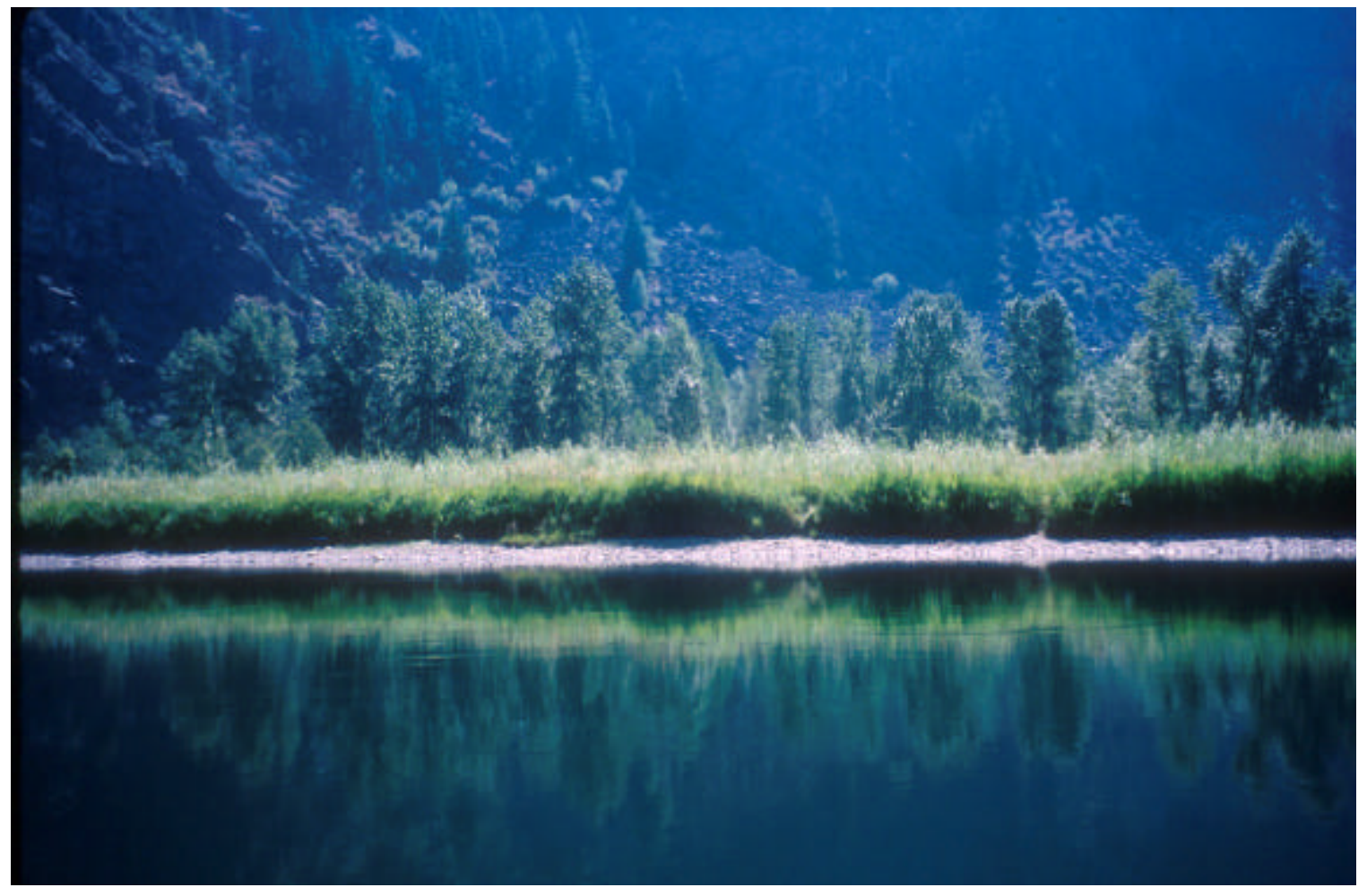

Figure 3. Cottonwood recruitment on the Big Bar transect site, Moyie study reach. (cottonwood saplings can been seen above the reed canarygrass in the foreground). 


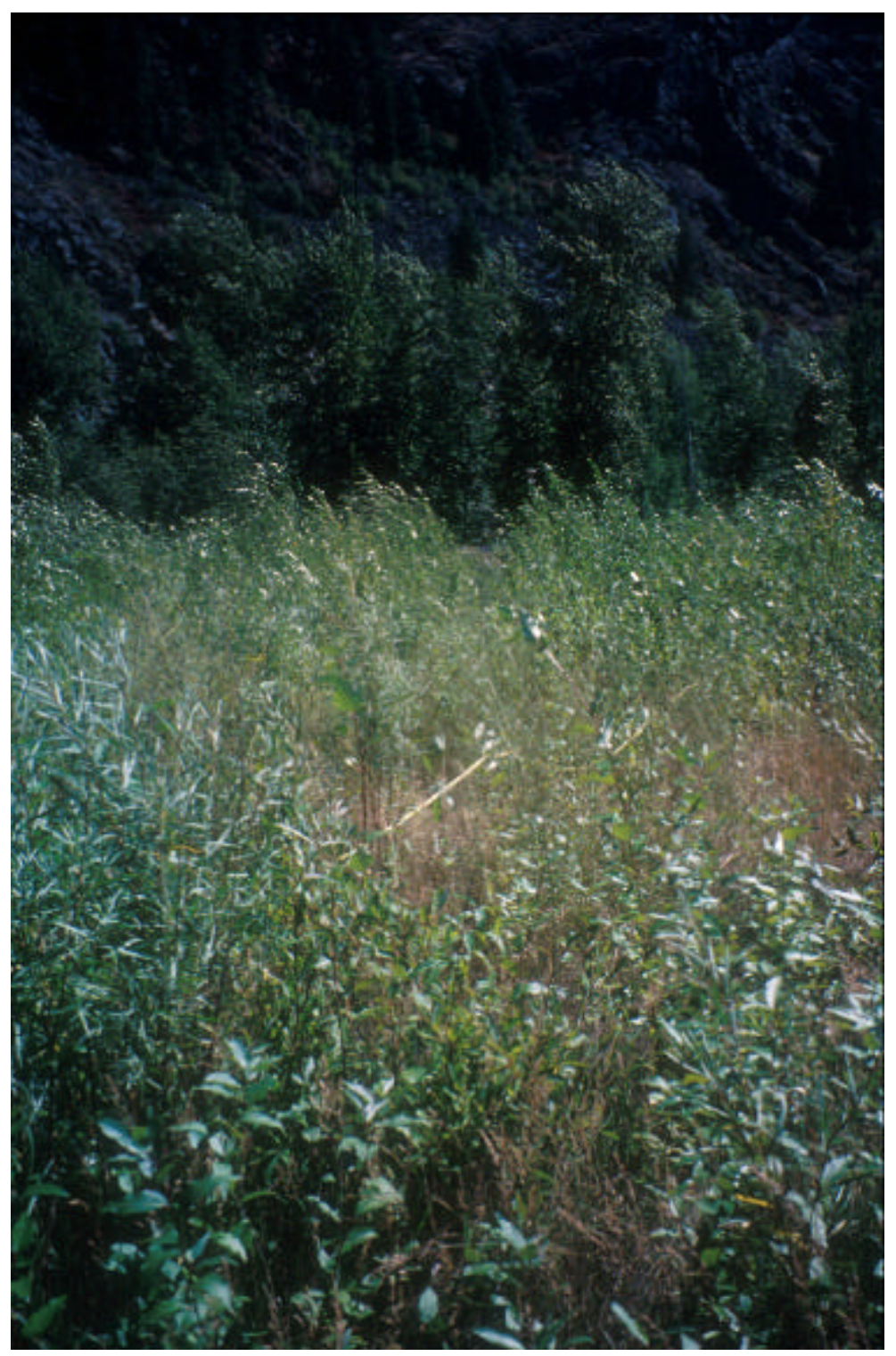

Figure 4. Closeup of cottonwood recruitment on the Big Bar transect site, Moyie study reach. 


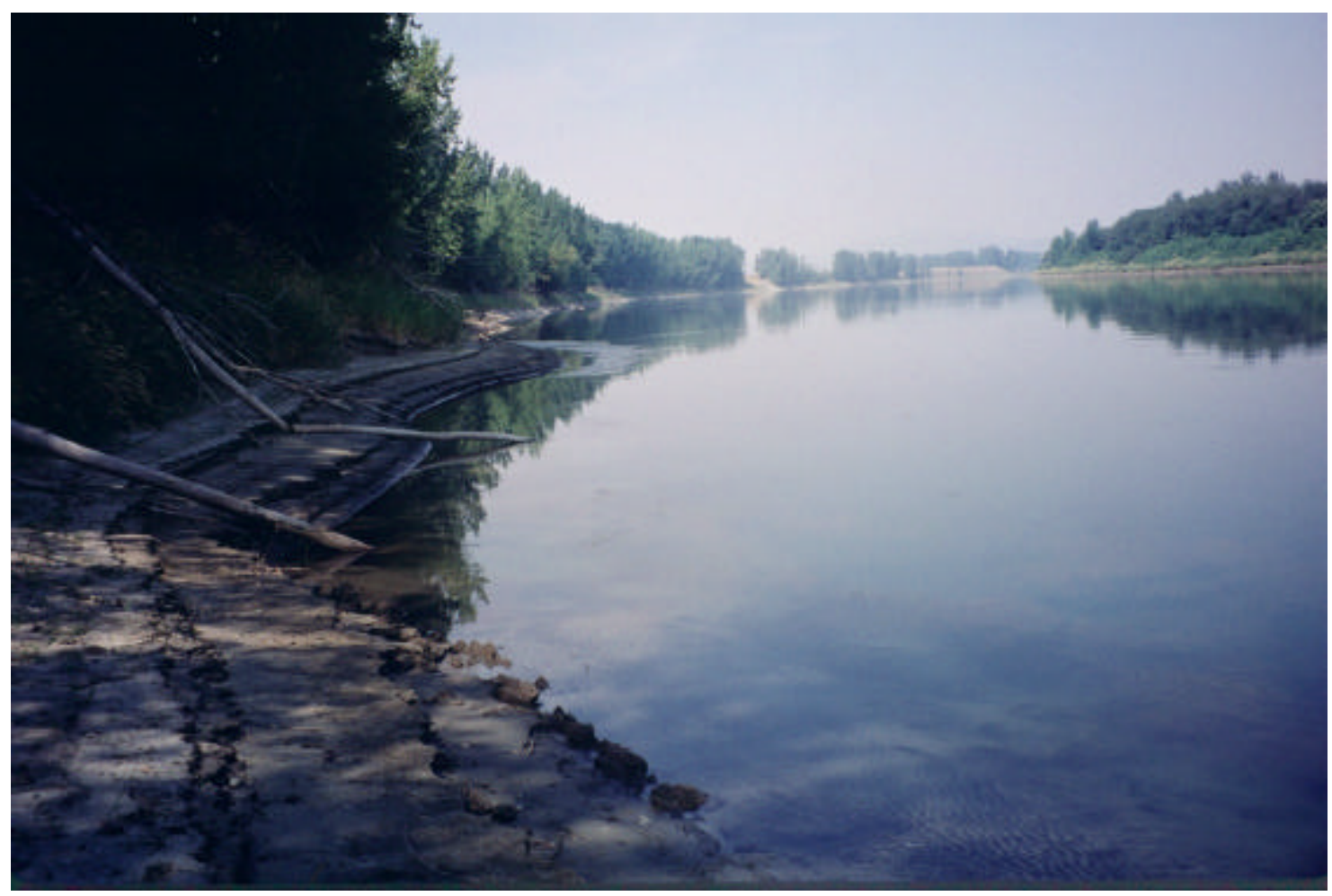

Figure 5. Vegetation on the dike downstream of Deep Creek, adjacent to the Kootenai National Wildlife Refuge. 


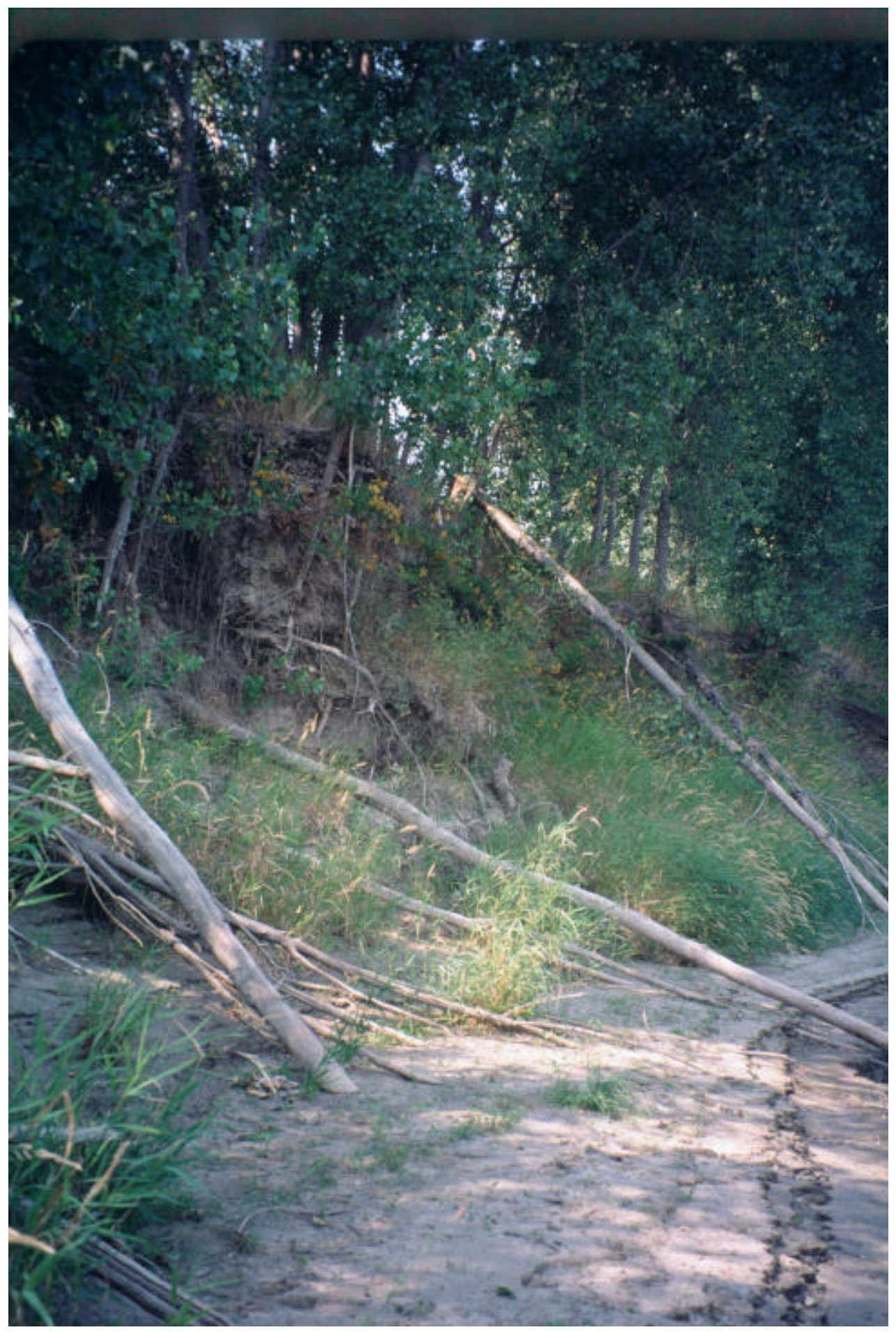

Figure 6. Closeup of cottonwood recruitment on the Big Bar transect site, Moyie study reach. 


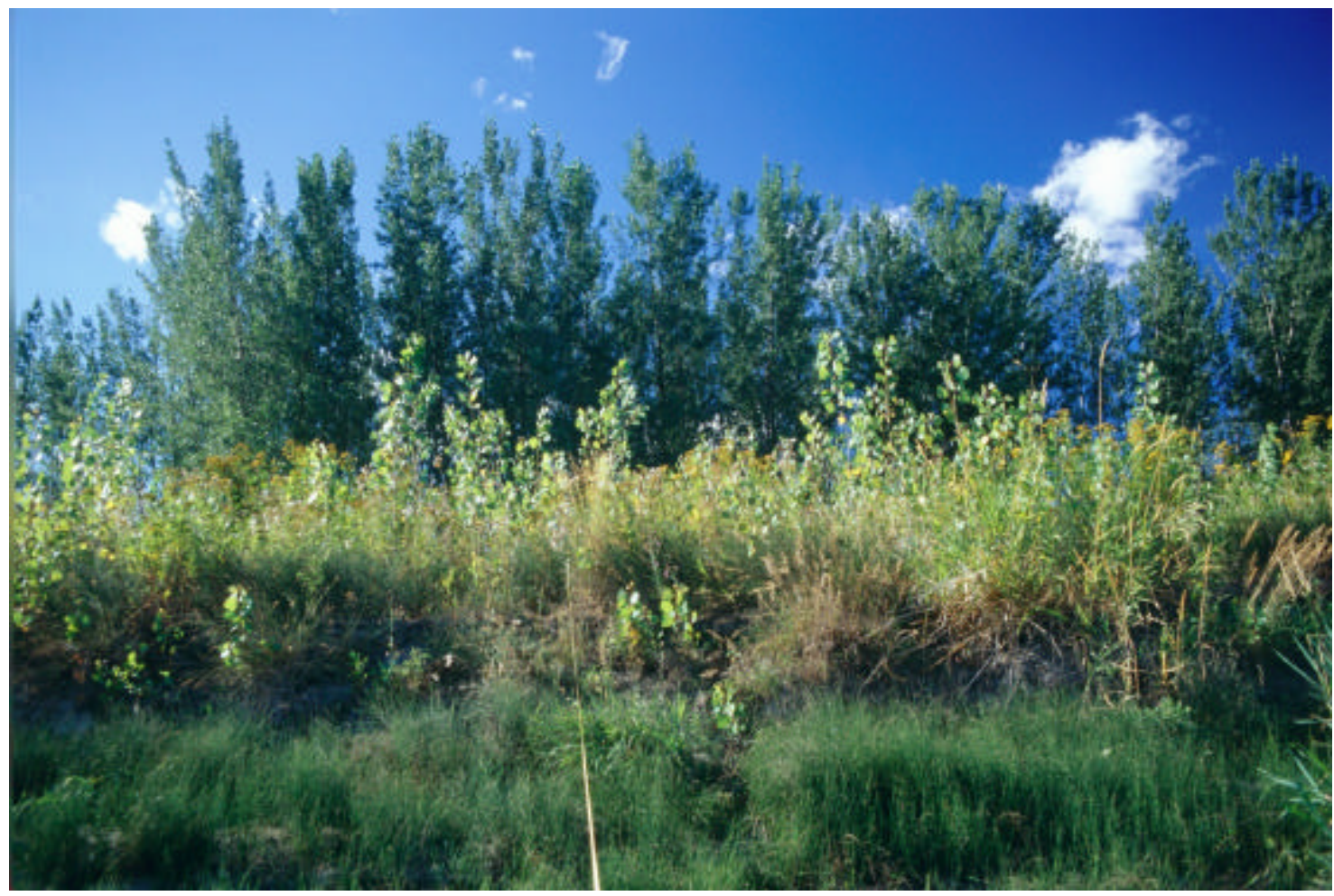

Figure 7. Two generation of cottonwood recruitment in the Copeland reach. 


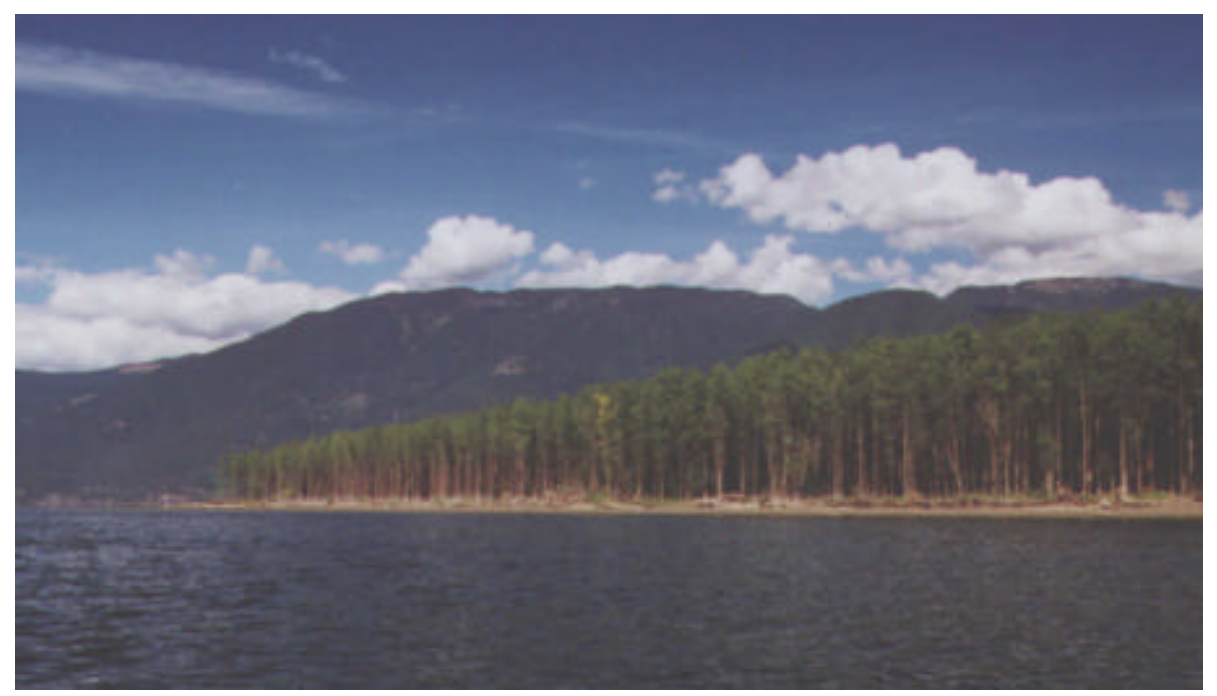

Figure 8. Cottonwood on the scroll bar extending out into Kootenay Lake. Transects were established on the opposite side of the bar.

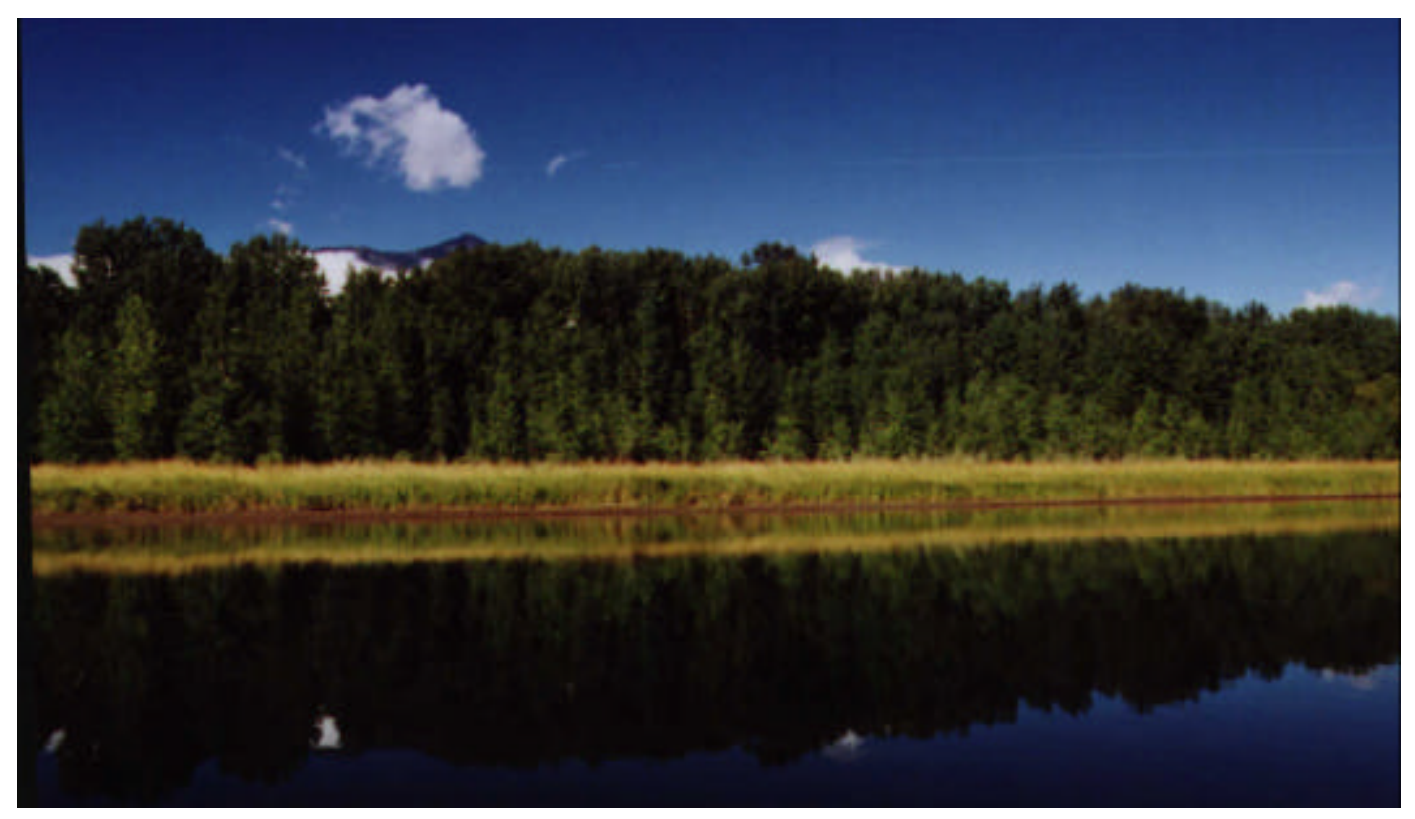

Figure 9. Two age classes of cottonwood and the dense stand of reed canary grass on the scroll bar extending into Kootenay Lake. (Transects 30-33 were established in this area). 


\section{APPENDIX II. PHOTOGRAPHS AND MAPPING OF THE BOUNDARY CREEK AREA, 1914 TO 1996.}



Figure 1. 1914 photograph of the Kootenai River floodplain, looking south from the west side of the valley close to the Canada/US border near Smith Creek.

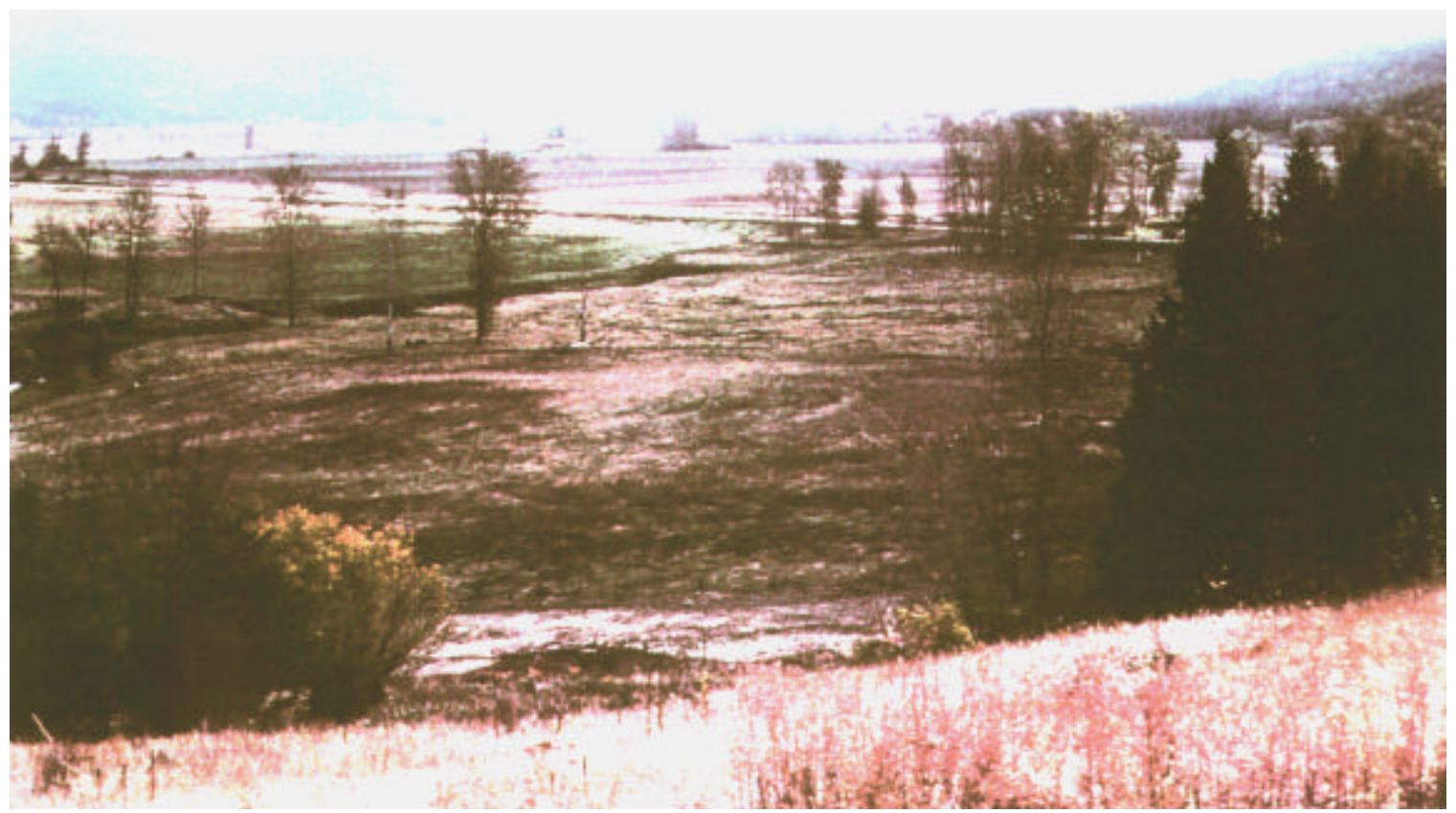

Figure 2. A 1998 photograph taken at the same location.

(The 1914 photo is from USDA 1914, the more recent photo was provided by the Idaho Fish and Game Department). 


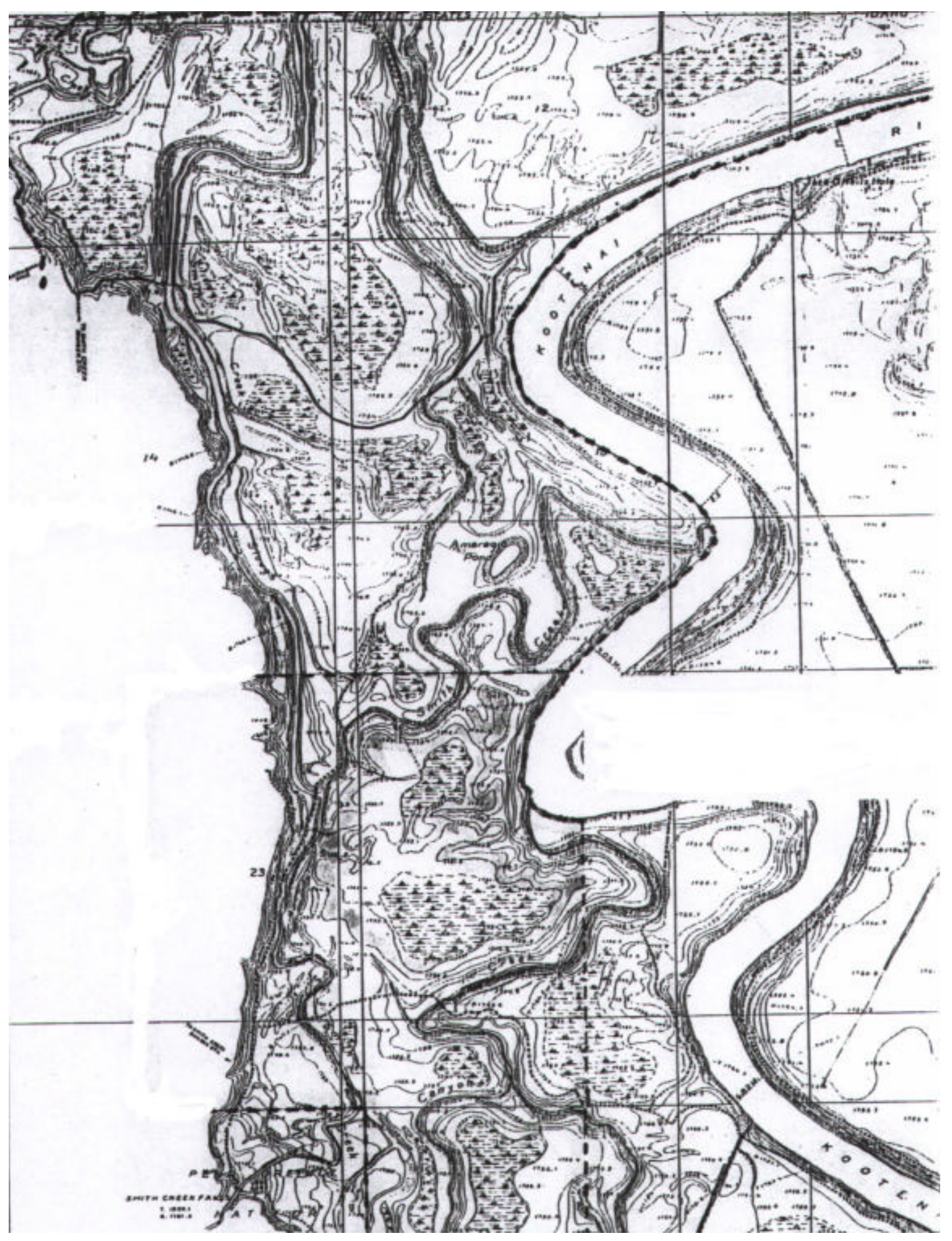

Figure 3. Early survey mapping (1928) of the Kootenai River floodplain south of the Canada/US border near Boundary Creek. * 


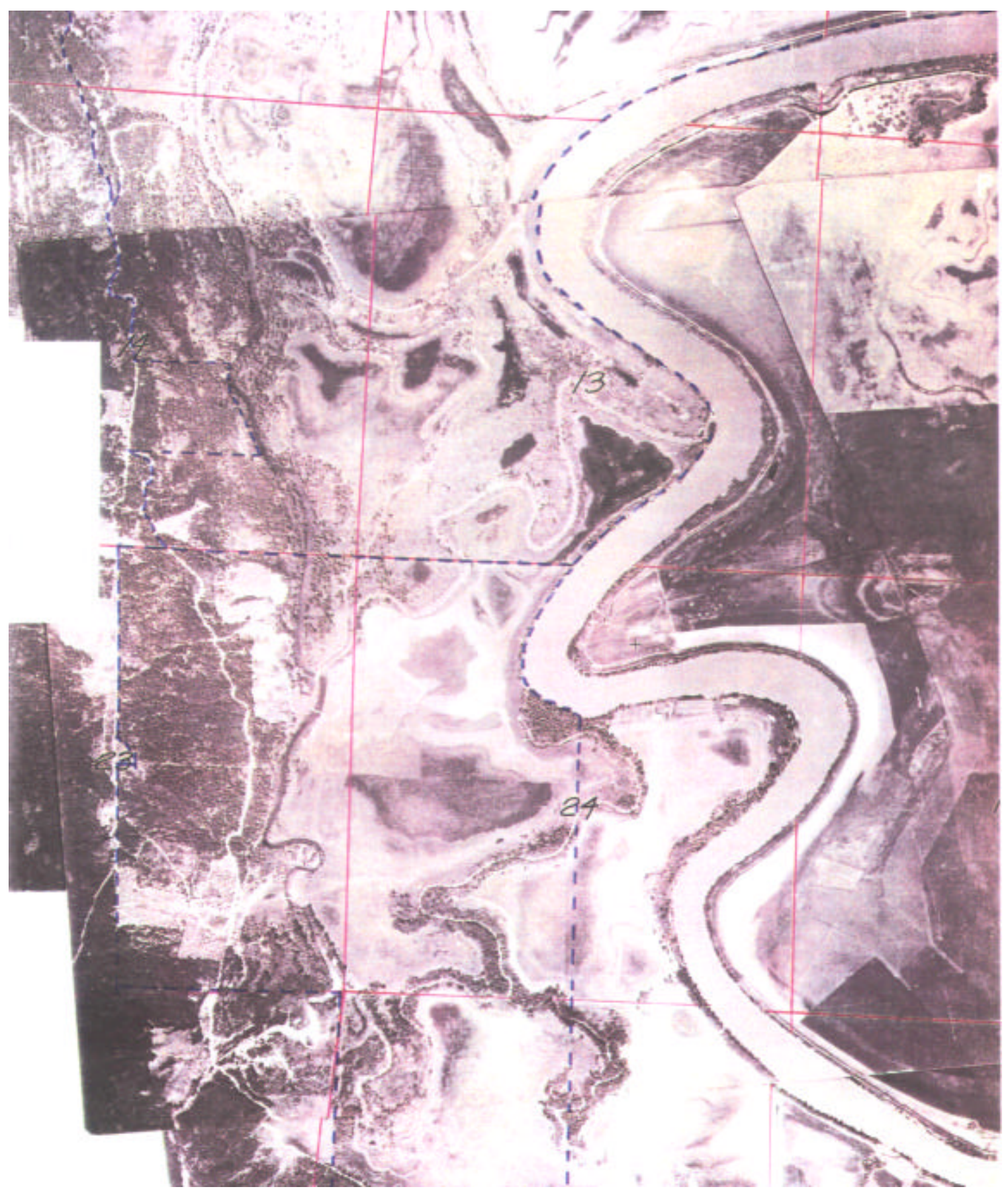

Figure 4. An early air photo (1934) of the Kootenai River floodplain south of the Canada/US border near Boundary Creek. * 


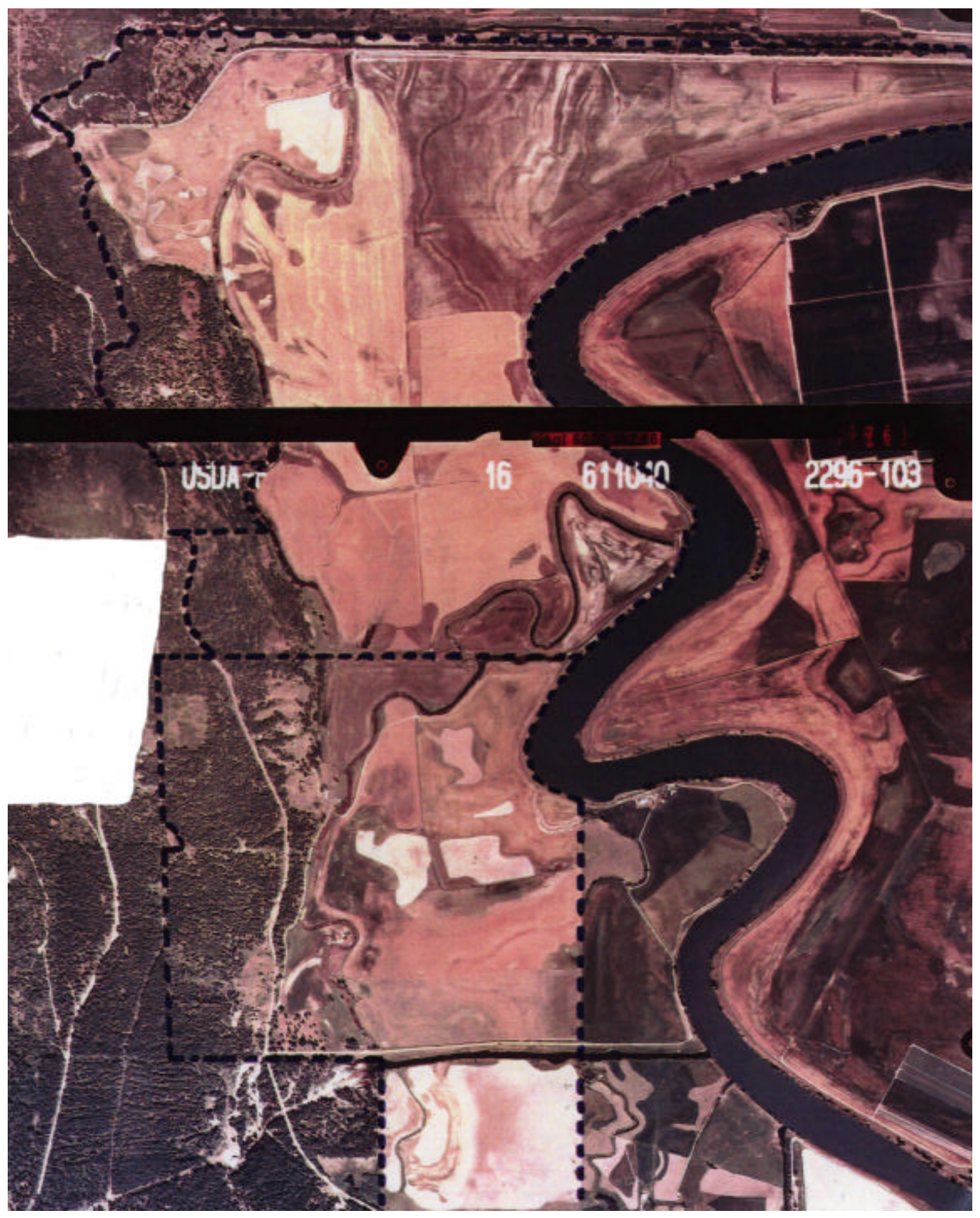

Figure 5. 1996 air photo montage of the Kootenai River floodplain south of the Canada/US border near Boundary Creek.

(Photographs and maps provided by the Idaho Department of Fish and Game Department). 


\section{APPENDIX III. OTHER MANAGEMENT OPTIONS FOR MAINTAINING COTTONWOOD STANDS.}

There are 6 areas where action is possible and would be effective.

- Management of cottonwood on tributary confluence areas

- Plantings of willow and cottonwood stands

- Cattle and grazing management

- Acquisition and conservation easements

- Actions to maintain cottonwood stands in tributaries downstream of the Libby dam

- Actions to maintain cottonwood stands in upstream areas of the sub-basin.

\section{MANAGEMENT OF COTTONWOOD ON TRIBUTARY INFLOW AREAS}

Pre-settlement it is likely that major cottonwood stands occurred where tributary streams flowed out onto the Kootenai floodplain. In the Columbia wetlands, which is a very similar area in terms of geomorphology and ecological conditions, the major cottonwood stands are found on the alluvial outflow areas of tributaries (Jamieson and Hennan 1998). In some areas, these tributary streams have been channelized (Deep Creek), in others, such as the Goat River, they remain in a more or less natural channel and cottonwood recruitment, as a result of the hydrograph of the tributary stream, is occurring. These are therefore among the most important sites for maintaining cottonwood presence in the floodplain. Potential sites include:

- The outflow channel of Deep Creek, (re-meandering channel across floodplain)

- The lower portion of Myrtle Creek (North edge of Kootenai Wildlife Refuge)

- Others creek outflows on the US side (Ball, Trout, Fisher, Cow and Boundary Creeks on west side, Mission Creek on east side).

- Corn creek and Summit Creek in CVWMA on the Canadian side.

- Duck Creek on the east side (lower portion is in CVWMA).

- Goat River. This site is a major opportunity for maintaining cottonwood stands in the long term. There is a complex set of issues in this area (burbot spawning, flooding threats to private land, other fisheries values) that are presently being studied in the area (B. Green, pers. com.). 


\section{PLANTINGS OF WILLOW AND COTTONWOOD STANDS.}

The recruitment of poplar seedlings can be promoted through the artificial disturbance and irrigation of floodplain soils (Friedman et al. 1995). During the spring, non-native vegetation is cleared to expose mineral substrates. These substrates are then scarified and plowed to further loosen surface soils. During subsequent periods of seed dispersal, these exposed soils are irrigated to capture the seed released from nearby mature cottonwood stands. In the absence of natural seedfall, seeds can also be collected and sown on these exposed floodplain soils. Following seed germination, more intense applications of irrigation water $(5-8 \mathrm{~cm}$ of $\mathrm{H} 2 \mathrm{O} / 24 \mathrm{hr}$ period, once a week) are necessary to promote the growth of roots toward the alluvial water table. This periodic flooding also acts to deter the establishment of non-native weeds. If the site is more than 1.5 meters above the level that is maintained in a wetted condition by summer base flows, then irrigation should be continued during the following growing season to ensure successful establishment. This approach, using seed fall from natural sources, tends to promote the establishment of genetically diverse populations that are well adapted to the site.

Cottonwoods can also be restored by artificial regeneration from cuttings. Ideally, planting material is collected from nearby native stands. Where local sources are unavailable, preference should be given to stands in a similar ecological zone from neighbouring basins. For collection, stands of min. 0.5 hectare, with evidence of genetic diversity are preferred (spring and fall phenology, sex ratio, canopy architecture, are good indicators). Stands at the confluence of streams are likely to harbour more genetic variation. If only isolated native stands available, breeding among the native residuals may be needed to broaden the genetic base of planting materials.

Where rapid restoration is imperative, especially on stressful sites, the first phase may be launched with proven hybrid material to stabilize riverbanks. It can later be followed with gradual substitution of (slower growing) native material. Pole stage trees 5-10 feet tall can also be planted, with plastic tubes around the truck to protect the tree from browsing. These nursery trees are available from Aberdeen Plant Materials, Aberdeen, Idaho. DeFrancesco 2001, Skrison and Sturtevant, 1999 and Clayton et al. 1998 provide further data on tests of these and related restoration strategies.

Plantings of cottonwood could be considered on some lands below the dike if the moisture regime is appropriate, especially in the set of meanders between Shortie' Island and the Copeland bridge. Other options may exist on the Boundary Creek Wildlife Management Area that is managed by the Idaho Fish and Game Department and on the Kootenai National Wildlife Refuge. Any such work would have to be coordinated with the ongoing work on the part of the University of Idaho, the Kootenai Tribe (S. Soults, pers. comm.) and the Corp of Engineers, looking at the restoration of riparian function and the issue of dike erosion related to higher flows for sturgeon (US FWS 2000). Interest in looking at means to maintain cottonwood stands in the long term has been expressed by the managers and staff at the CVWMA in Canada. 


\section{CATTLE AND GRAZING MANAGEMENT}

A range of options for fencing and other controls to reduce the impact of cattle grazing in riparian areas have been identified in recent years. These tools could be applied where cattle are being grazed along the Kootenai River. The Kootenai Tribe is working on this issue on Kootenai Tribal allotment areas. Grazing on the dikes is a management concern on the Canadian side.

\section{ACQUISITION AND CONSERVATION EASEMENTS}

Most lands along the Kootenai River and its tributaries are private due to early patterns of settlement. A variety of organizations are involved in the acquisition of lands and the establishment of conservation easements on both sides of the border. Recent work on the Canadian side (Jamieson et al. 2001) on hardwoods suggests that such actions in alluvial floodplain areas on mainstem rivers should be considered a priority. Several areas on the Kootenai have been acquired or established for conservation values, but few of these provide options for maintaining riparian process.

\section{ACTIONS TO MAINTAIN COTTONWOOD STANDS IN TRIBUTARIES DOWNSTREAM OF THE LIBBY DAM}

Some work could be carried out in the downstream tributaries where close to normative flows still occur to compensate for the lack of options on the mainstem river. Some small dams occur on these tributaries (sub-basin summary) but are not flow regulating. However, there are few alluvial floodplain areas on these tributaries since most are located in incised valleys.

\section{ACTIONS TO MAINTAIN COTTONWOOD STANDS IN UPSTREAM AREAS OF THE SUB-BASIN.}

Actions could be considered to optimize values in the reaches upstream of Libby dam, where the alluvial floodplain reach on the mainstem is still in good condition. However, all of these reaches are located in Canada. There are some actions that could be considered where there would be an obvious US benefit or actions that are related to responsibilities associated with the impacts of the Libby dam. These are:

- Measures the losses of riparian habitats due to flooding by the Libby Reservoir on the Canadian side.

- Consider restoration work at the head of the reservoir at Wardner, B.C. in the upper portion of the drawdown zone. (See section 6.4.)

There are other actions that could be undertaken that would provide ecosystem benefits for the entire Kootenai system. There are, however, some major political and administrative challenges provided by doing this kind of work in an international sub- 
basin. Some leadership in this area however, is being provided by the NWPPC and the Columbia Basin Trust, an example of which is this project.

Restoration options in the Canadian upstream portion of the sub-basin include:

- The Canal Flats to Wardner reach is an alluvial floodplain area that is in a close to natural condition through much of its length and has a normative hydrograph. They thus provide an opportunity for mitigation at comparatively low cost.

- International cost sharing on cattle management and conservation easements/acquisition programs could be considered for this reach. Jamieson et al. 2001 suggests the need for an inventory of acquisition options and a problem analysis for this alluvial reach as a first step toward a program of conservation easements and improved grazing practise on this reach.

- There is an important alluvial reach with extensive cottonwood stands in the Elkford to Elko reach of the Elk River. There are major development pressures along this reach as a result of the recent expansion of Fernie as a destination resort. Acquisition options along this reach are identified by Jamieson and Allen 1997. The Nature Conservancy of Canada is exploring options for acquisition in this area, combining a need to maintain cross-valley wildlife corridors and to maintain riparian values.

\section{LITERATURE CITED}

Clayton, S.R, B.J Moynahan, T.G. Parker and T.R. Weisenburger, W.H. Thompson and P.L. Hansen, 1998. Upper Clark Fork River Streambank Stabilization Pilot Study. Excerpts from Report, Univ. of Montana. Available at: www.rwrp.umt.edu/projects.

DeFrancesco, D. 2001.Factors influencing Black Cottonwood (Populus tricocarpa) recruitment on the Upper Clark Fork River, western Montana. Univ. of Montana. Abstract of report available at: www.rwrp.umt.edu/projects.

Friedman J.M., M.L. Scott, and W.M. Lewis.1995. Restoration of riparian forest using irrigation, artificial disturbance and natural seedfall. Environmental Management 19:547-557.

Jamieson, B., E.B. Peterson, N.M. Peterson and I. Parfitt. 2001. The conservation of hardwoods and associated wildlife in the CBFWCP area in southeastern British Columbia. Prepared for: Columbia Basin Fish and Wildlife Compensation Program, Nelson, B.C. By: BioQuest International Consulting Ltd. and Western Ecological Services. Available at www.cbfwcp.org

Skrison, R. and P. Sturtevant, 1999. ed. Watershed Management to protect declining species. AWRA's 1999 Annual Water Resources Conference.TPS 99-4,561pp. 